\title{
Legumes for mitigation of climate change and the provision of feedstock for biofuels and biorefineries. A review
}

\author{
Erik Steen Jensen • Mark B. Peoples • Robert M. Boddey • Peter M. Gresshoff • \\ Henrik Hauggaard-Nielsen • Bruno J.R. Alves • Malcolm J. Morrison
}

Accepted: 8 September 2011 / Published online: 19 October 2011

(C) INRA and Springer-Verlag, France 2011

\begin{abstract}
Humans are currently confronted by many global challenges. These include achieving food security for a rapidly expanding population, lowering the risk of climate change by reducing the net release of greenhouse gases into the atmosphere due to human activity, and meeting the increasing demand for energy in the face of dwindling reserves of fossil energy and uncertainties about future reliability of supply. Legumes deliver several important services to societies. They provide important sources of oil, fiber, and protein-rich food and feed while supplying nitrogen
\end{abstract}

\section{E. S. Jensen $(\bowtie)$}

Department of Agrosystems,

Swedish University of Agricultural Sciences,

P.O. Box 104, 23053 Alnarp, Sweden

e-mail: Erik.Steen.Jensen@SLU.SE

M. B. Peoples

CSIRO Sustainable Agriculture Flagship, CSIRO Plant Industry,

G.P.O. Box 1600, Canberra, ACT 2601, Australia

R. M. Boddey $\cdot$ B. J.R. Alves

Embrapa Agrobiologia,

Caixa Postal 75.505, 23890-000 Rio de Janeiro, Brazil

P. M. Gresshoff

Center for Integrative Legume Research,

University of Queensland,

St Lucia, QLD 4072, Australia

H. Hauggaard-Nielsen

Biosystems Division,

Risø DTU National Laboratory for Sustainable Energy,

4000 Roskilde, Denmark

M. J. Morrison

Agriculture and Agri-Food Canada, Eastern Cereal and Oilseed

Research Centre, Central Experimental Farm,

Ottawa, Ontario, Canada K2E 6A8
(N) to agro-ecosystems via their unique ability to fix atmospheric $\mathrm{N}_{2}$ in symbiosis with the soil bacteria rhizobia, increasing soil carbon content, and stimulating the productivity of the crops that follow. However, the role of legumes has rarely been considered in the context of their potential to contribute to the mitigation of climate change by reducing fossil fuel use or by providing feedstock for the emerging biobased economies where fossil sources of energy and industrial raw materials are replaced in part by sustainable and renewable biomass resources. The aim of this review was to collate the current knowledge regarding the capacity of legumes to (1) lower the emissions of the key greenhouse gases carbon dioxide $\left(\mathrm{CO}_{2}\right)$ and nitrous oxide $\left(\mathrm{N}_{2} \mathrm{O}\right)$ compared to $\mathrm{N}$-fertilized systems, (2) reduce the fossil energy used in the production of food and forage, (3) contribute to the sequestration of carbon (C) in soils, and (4) provide a viable source of biomass for the generation of biofuels and other materials in future biorefinery concepts. We estimated that globally between 350 and $500 \mathrm{Tg} \mathrm{CO}_{2}$ could be emitted as a result of the 33 to $46 \mathrm{Tg} \mathrm{N}$ that is biologically fixed by agricultural legumes each year. This compares to around $300 \mathrm{Tg} \mathrm{CO} \mathrm{CO}_{2}$ released annually from the manufacture of $100 \mathrm{Tg}$ fertilizer $\mathrm{N}$. The main difference is that the $\mathrm{CO}_{2}$ respired from the nodulated roots of $\mathrm{N}_{2}$-fixing legumes originated from photosynthesis and will not represent a net contribution to atmospheric concentrations of $\mathrm{CO}_{2}$, whereas the $\mathrm{CO}_{2}$ generated during the synthesis of $\mathrm{N}$ fertilizer was derived from fossil fuels. Experimental measures of total $\mathrm{N}_{2} \mathrm{O}$ fluxes from legumes and $\mathrm{N}$-fertilized systems were found to vary enormously $\left(0.03-7.09\right.$ and $0.09-18.16 \mathrm{~kg} \mathrm{~N}_{2} \mathrm{O}-\mathrm{N} \mathrm{ha}{ }^{-1}$, respectively). This reflected the data being collated from a diverse range of studies using different rates of $\mathrm{N}$ inputs, as well as the large number of climatic, soil, and management variables known to influence denitrification and the portion of 
the total $\mathrm{N}$ lost as $\mathrm{N}_{2} \mathrm{O}$. Averages across 71 site-years of data, soils under legumes emitted a total of $1.29 \mathrm{~kg} \mathrm{~N}_{2} \mathrm{O}-\mathrm{N} \mathrm{ha}{ }^{-1}$ during a growing season. This compared to a mean of $3.22 \mathrm{~kg} \mathrm{~N}_{2} \mathrm{O}-\mathrm{N} \mathrm{ha}^{-1}$ from 67 site-years of $\mathrm{N}$-fertilized crops and pastures, and $1.20 \mathrm{~kg} \mathrm{~N}_{2} \mathrm{O}-\mathrm{N}$ ha $^{-1}$ from 33 site-years of data collected from unplanted soils or unfertilized nonlegumes. It was concluded that there was little evidence that biological $\mathrm{N}_{2}$ fixation substantially contributed to total $\mathrm{N}_{2} \mathrm{O}$ emissions, and that losses of $\mathrm{N}_{2} \mathrm{O}$ from legume soil were generally lower than $\mathrm{N}$-fertilized systems, especially when commercial rates of $\mathrm{N}$ fertilizer were applied. Elevated rates of $\mathrm{N}_{2} \mathrm{O}$ losses can occur following the termination of legume-based pastures, or where legumes had been green- or brown-manured and there was a rapid build-up of high concentrations of nitrate in soil. Legume crops and legume-based pastures use 35\% to $60 \%$ less fossil energy than $\mathrm{N}$-fertilized cereals or grasslands, and the inclusion of legumes in cropping sequences reduced the average annual energy usage over a rotation by $12 \%$ to $34 \%$. The reduced energy use was primarily due to the removal of the need to apply $\mathrm{N}$ fertilizer and the subsequently lower $\mathrm{N}$ fertilizer requirements for crops grown following legumes. Life cycle energy balances of legume-based rotations were also assisted by a lower use of agrichemicals for crop protection as diversification of cropping sequences reduce the incidence of cereal pathogens and pests and assisted weed control, although it was noted that differences in fossil energy use between legumes and $\mathrm{N}$ fertilized systems were greatly diminished if energy use was expressed per unit of biomass or grain produced. For a change in land use to result in a net increase $\mathrm{C}$ sequestration in soil, the inputs of $\mathrm{C}$ remaining in plant residues need to exceed the $\mathrm{CO}_{2}$ respired by soil microbes during the decomposition of plant residues or soil organic $\mathrm{C}$, and the $\mathrm{C}$ lost through wind or water erosion. The net N-balance of the system was a key driver of changes in soil $\mathrm{C}$ stocks in many environments, and data collected from pasture, cropping, and agroforestry systems all indicated that legumes played a pivotal role in providing the additional organic $\mathrm{N}$ required to encourage the accumulation of soil $\mathrm{C}$ at rates greater than can be achieved by cereals or grasses even when they were supplied with $\mathrm{N}$ fertilizer. Legumes contain a range of compounds, which could be refined to produce raw industrial materials currently manufactured from petroleum-based sources, pharmaceuticals, surfactants, or food additives as valuable by-products if legume biomass was to be used to generate biodiesel, bioethanol, biojet A1 fuel, or biogas. The attraction of using leguminous material feedstock is that they do not need the inputs of $\mathrm{N}$ fertilizer that would otherwise be necessary to support the production of high grain yields or large amounts of plant biomass since it is the high fossil energy use in the synthesis, transport, and application of $\mathrm{N}$ fertilizers that often negates much of the net $\mathrm{C}$ benefits of many other bioenergy sources. The use of legume biomass for biorefineries needs careful thought as there will be significant trade-offs with the current role of legumes in contributing to the organic fertility of soils. Agricultural systems will require novel management and plant breeding solutions to provide the range of options that will be required to mitigate climate change. Given their array of ecosystem services and their ability to reduce greenhouse gas emissions, lower the use of fossil energy, accelerate rates of $\mathrm{C}$ sequestration in soil, and provide a valuable source of feedstock for biorefineries, legumes should be considered as important components in the development of future agroecosystems.

Keywords Legumes $\cdot$ Biological $\mathrm{N}_{2}$ fixation $\cdot$ Carbon sequestration · Greenhouse gases $\cdot$ Biorefinery $\cdot$ Biofuels

\section{Contents}

1. Introduction $\ldots \ldots \ldots \ldots \ldots \ldots \ldots \ldots \ldots$

2. The potential for legumes to mitigate climate change .3

2.1 Mitigation of green-house gas emissions . . . . . 4 4 2.1.1 $\mathrm{CO}_{2}$ emissions arising from $\mathrm{N}$-fertilizer production and symbiotic $\mathrm{N}_{2}$ fixation. . . . . . . 4

2.1.2 $\mathrm{N}_{2} \mathrm{O}$ emissions. . . . . . . . . . . . . 5 2.1.2.1 $\mathrm{N}_{2} \mathrm{O}$ emissions from legume and $\mathrm{N}$ fertilized systems. . . . . . . . . .6

2.1.2.2 $\mathrm{N}_{2} \mathrm{O}$ emissions derived from legume residues. . . . . . . . . . . . . 10

2.2 Comparisons of energy use by legume-based and $\mathrm{N}$-fertilized systems. . . . . . . . . . 12

2.3 Soil carbon sequestration and land use change. . 13

2.3.1 Legume effects on soil carbon sequestration. . . . . . . . . . . . . . . 14

2.3.2 Pastures. . . . . . . . . . . . . . . 15

2.3.3 Cropping sequences. ......... 16

2.3.4 Woody perennial legumes. ........ 18

3. A role for legumes to replace fossil resources? . . . . .19

3.1 Legume biomass yields potentials and constituents

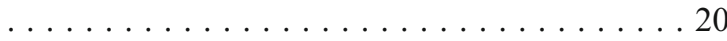

3.2 Legumes as biorefinery feedstocks for biofuels, materials, and chemicals. . . . . . . . . 22

3.2.1 Biofuels. . . . . . . . . . . . . . . 24

3.2.1.1 Bioethanol. . . . . . . . . . . . 24

3.2.1.2 Biodiesel. . . . . . . . . . . .25

3.2.2 Biogas and digestate for fertilizer. . . . . . 27

3.2.3 Thermochemical conversion for production of heat, electricity, and biochar. . . . . . . 28

3.2.4 Materials and chemicals. . . . . . . . . . . 29

4. Concluding remarks. . . . . . . . . . . . . . .29

5. Acknowledgments. . . . . . . . . . . . . . 30

6. References. . . . . . . . . . . . . . . . . . 30 


\section{Introduction}

Biomass from agriculture, forestry, and marine environments is expected to play an important role in replacing scarce energy sources in the transition from a fossil economy to a biobased economy (IEA 2009; Bessou et al. 2010; Fairley 2011). A biobased economy is defined as the replacement of fossil fuels in the production of industrial chemicals, transportation fuels, electricity, heat, and other products by biomass in so-called biorefinery concepts. The political and scientific arguments for this transition are multiple: diversification of energy sources due to declining fossil reserves (energy security), less dependence on fossil raw material exporters (energy security), new uses of biomass to stimulate rural development, and the reduction of greenhouse gases (GHG) to mitigate global climate change (Bessou et al. 2010; Langeveld and Sanders 2010).

Climate change is brought about by the increasing atmospheric content of a range of gases such as carbon dioxide $\left(\mathrm{CO}_{2}\right)$, nitrous oxide $\left(\mathrm{N}_{2} \mathrm{O}\right)$, methane $\left(\mathrm{CH}_{4}\right)$, ozone $\left(\mathrm{O}_{3}\right)$, and chlorofluorocarbons (CFCs). These greenhouse gases (GHG) are all increasing as a result of human activity (e.g., Table 1; Blasing 2010). As the GHG concentration increases, more sunlight is absorbed and the energy converted to heat. At the current rate of GHG production, the average surface temperatures of the planet are predicted to rise by $2^{\circ} \mathrm{C}$ or more by 2100 (IPCC 2007). Such a warming could impact terrestrial ecosystems either positively or negatively depending on current regional climatic conditions.

Rising concentrations of $\mathrm{CO}_{2}$ are the main concern since $\mathrm{CO}_{2}$ emissions from the combustion of fossil fuels account for $>50 \%$ of the estimated increased greenhouse effect (IPCC 2007). The agricultural contribution to the global GHG emission has been estimated to be $13.5 \%$ of the total GHG $\mathrm{CO}_{2}$-equivalents (IPCC 2007) and is derived from (1) the use of fossil energy for the manufacture and transport of fertilizer nitrogen $(\mathrm{N})$, other fertilizers and agrichemicals, and the consumption of petroleum-based fuels for on-farm machinery operation; (2) changes in land-use that release GHG due to the net decomposition of soil organic matter, or when the carbon $(\mathrm{C})$ in the wood is converted to $\mathrm{CO}_{2}$ by burning when land is deforested for cropping or livestock; (3) the release of $\mathrm{N}_{2} \mathrm{O}$ from soil as a result of inefficiencies in crop recovery of fertilizer and other sources of $\mathrm{N}$; and (4) $\mathrm{CH}_{4}$ released from the enteric digestion of forage within the rumen of livestock, on-farm manure management, and rice (Oryza sativa) cultivation on wetlands (Jenkinson 2001; Crews and Peoples 2005; Bessou et al. 2010). To mitigate climate change from agriculture, it is important to adopt strategies that reduce these sources of GHG emissions.

Leguminous crops (e.g., field pea, Pisum sativum; faba bean, Vicia faba; chickpea, Cicer arietinum; soybean,
Glycine max), forages [e.g., clovers, Trifolium spp.; alfalfa (lucerne), Medicago sativa], trees, and shrubs (e.g., species of Leucaena, Callinadra, Gliricidia, Acacia, and Sesbania) provide a range of agroecosystems services for humans. These include (1) N (protein)-rich foods, feeds, and greenmanures; (2) a lowering of the need for fertilizer $\mathrm{N}$ to support crop and pasture production as the result of contributions of symbiotically fixed dinitrogen $\left(\mathrm{N}_{2}\right)$ to the growth of the legume host, and the subsequent improvement of soil fertility through inputs of legume organic residues (Rochester et al. 2001; Jensen and HauggaardNielsen 2003; Crews and Peoples 2004); (3) improvements in soil structural characteristics (Rochester et al. 2001; McCallum et al. 2004); (4) direct impacts on soil biology by reducing the incidence of cereal root pathogens, and/or encouraging beneficial microorganisms (Kirkegaard et al. 2008; Osborne et al. 2010); (5) diversification of species grown in rotations reducing the requirement for pesticides and other agrichemicals, encouraging systems resilience and biodiversity (Jensen and Hauggaard-Nielsen 2003; Köpke and Nemecek 2010); (6) deep-rooted perennial legumes reducing the risk of groundwater contamination by nitrate $\left(\mathrm{NO}_{3}{ }^{-}\right)$, or the development of dryland salinity, due to their ability to grow and extract water all year round (Angus et al. 2001; Entz et al. 2001; Lefroy et al. 2001); and (7) the revegetation and reclamation of degraded or cleared lands (Thrall et al. 2005; Chaer et al. 2011; De Faria et al. 2011). Even though legumes obtain $\mathrm{N}$ through biological nitrogen fixation (BNF), rather than through fossil energy-derived fertilizer $\mathrm{N}$, they are generally not considered as a mitigation option (Smith et al. 2007). With the exception of soybean, legumes are also usually not regarded as particularly relevant as biomass crops or as crop components as feedstock in biorefinery for biofuel and/or biomaterials production (Venendaal et al. 1997; Brehmer et al. 2008; Bessou et al. 2010).

This paper reviews the potential new roles for the use of legumes in future agriculture to (1) reduce the emissions of the key GHG $\mathrm{CO}_{2}$ and $\mathrm{N}_{2} \mathrm{O}$; (2) lower fossil energy consumption during the production of food, forage, and fiber; (3) increase the sequestering of organic $\mathrm{C}$ in soils; and (4) provide an energy-efficient biomass source for biorefineries to produce biofuels, chemicals, and materials to replace fossil-resource-derived products.

\section{The potential for legumes to mitigate climate change}

\subsection{Mitigation of greenhouse gas emissions}

As GHG concentrations rise, it has become increasingly important to account for losses of $\mathrm{CO}_{2}$ and $\mathrm{N}_{2} \mathrm{O}$ arising from agriculture (Table 1). Emissions of these gases may 
Table 1 The Global Warming Potential (GWP) of some major greenhouse gases and historic trends in changes in their atmospheric concentrations

\begin{tabular}{|c|c|c|c|c|c|c|}
\hline \multirow[t]{2}{*}{ Gas } & \multirow[t]{2}{*}{$\mathrm{GWP}^{\mathrm{a}}$ (100 year) } & \multicolumn{5}{|c|}{ Year and surface air concentration (ppm on a volume basis) } \\
\hline & & 1800 & 1900 & 1950 & 1995 & 2008 \\
\hline $\mathrm{CO}_{2}$ & 1 & 280 & 297 & 311 & 361 & 385 \\
\hline $\mathrm{CH}_{4}$ & 21 & 0.80 & 0.87 & 1.15 & 1.73 & 1.80 \\
\hline $\mathrm{N}_{2} \mathrm{O}$ & 298 & 0.28 & 0.28 & 0.29 & 0.31 & 0.32 \\
\hline
\end{tabular}

Collated from data presented by IPCC (2007); Lægreid et al. (1999); Blasing (2010)

${ }^{a}$ The GWP provides a simple measure of the radiative effects of emissions of various greenhouse gases integrated over a 100-year time horizon, relative to an equal mass of $\mathrm{CO}_{2}$ emissions

occur either directly as the result of farming activities (e.g., cultivation and harvesting) or indirectly during the production and transport of required inputs (e.g., fertilizers, herbicides, and pesticides). The potential role of $\mathrm{N}_{2}$-fixing legumes in reducing GHG emissions through direct effects on $\mathrm{CO}_{2}$ and $\mathrm{N}_{2} \mathrm{O}$ fluxes in the production of high-protein grain and forage will be compared to the applications of fertilizer $\mathrm{N}$ in the following sections.

\subsection{1 $\mathrm{CO}_{2}$ emissions arising from $\mathrm{N}$ fertilizer production and symbiotic $\mathrm{N}_{2}$ fixation}

A century after its invention, the Haber-Bosch process of ammonia $\left(\mathrm{NH}_{3}\right)$ production essentially remains unchanged. Ammonia is synthesized from a 3:1 volume mixture of $\mathrm{H}_{2}$ and $\mathrm{N}_{2}$ at elevated temperature and pressure in the presence of an iron catalyst (Smil 2001). All the $\mathrm{N}_{2}$ used is obtained from the air and the $\mathrm{H}_{2}$ can be obtained by either (a) partial oxidation of heavy fuel oil or coal, or (b) steam reforming of natural gas or other light hydrocarbons (natural gas liquids, liquefied petroleum gas, or naphtha; Smil 2001; Crews and Peoples 2004). It has been estimated that the fossil energy requirements associated with providing the high temperature and pressures and the generation of $\mathrm{H}_{2}$ feedstock required for the synthesis of $\mathrm{N}$ fertilizer represents $1-2 \%$ of the total world energy consumption (Smil 2001; Jenkinson 2001). It has also been calculated that the varying efficiencies of different processing plants result in the release of between 0.7 and $1.0 \mathrm{~kg}$ of $\mathrm{CO}_{2}-\mathrm{C}$ (equivalent to $2.6-3.7 \mathrm{~kg} \mathrm{CO}_{2}$ gas) per kilogram of $\mathrm{NH}_{3}-\mathrm{N}$ produced (Jenkinson 2001; Jensen and Hauggaard-Nielsen 2003). About half of the $\mathrm{CO}_{2}$ generated during $\mathrm{NH}_{3}$ production will be reused if the $\mathrm{NH}_{3}$ is converted to urea, which is the most widely used form of $\mathrm{N}$ fertilizer applied to agroecosystems $(67 \%$ of total fertilizer $\mathrm{N}$ consumed in 2007 ; IFA 2010). However, once the urea is applied to the soil, it is rapidly hydrolyzed by the enzyme urease to $\mathrm{NH}_{3}$ and the $\mathrm{CO}_{2}$ originally captured during urea production will also be released (Jenkinson 2001). Consequently, the annual global fertilizer production of around $100 \mathrm{Tg} \mathrm{N}\left(1 \mathrm{Tg}=10^{12} \mathrm{~g}\right.$; IFA
2010) manufactured with an efficiency of $2.6-3.7 \mathrm{~kg} \mathrm{CO}_{2}$ generated per kilogram of $\mathrm{N}$ synthesized represents around $300 \mathrm{Tg}$ of $\mathrm{CO}_{2}$ being released into the atmosphere each year.

There are nearly 18,000 legume species, many of major agricultural importance. Legumes range from herbaceous annuals plants to gigantic trees (e.g., Moreton Bay chestnut, Castanospermum australe). Many legumes possess the ability to form nitrogen-fixing symbioses with soil bacteria broadly called "rhizobia" (see Ferguson et al. 2010 for an upto-date review). The symbiosis is initiated through an exchange of chemical signals; specifically legume roots secrete not only sugars but also flavones and isoflavones. These exist as "chemical cocktails" of "rhizobial" gene activators and repressors, representing part of host specificity. For example, a bacterium that normally induces nodules in white clover will not nodulate or fix nitrogen with soybean, and vice versa. The flavone signal also works as a chemoattractant to "rhizobia" which then attach to root hairs in the susceptible zone right behind the growing root tip region [there are some exceptions to root hair nodulation processfor example groundnut (Arachis hypogae) where rhizobia rely upon entry through root cracks]. Here, they activate bacterial genes (nod and nol genes) that cooperate to synthesize and secrete a nodulation (Nod) factor. Nod factor perception leads to two interrelated processes, namely root hair/root cortex infection, and cortical and pericycle cell divisions. The combined meristems form the nascent root nodule, well-plumbed with a bifurcated vascular system, designed to provide photosynthate (usually as sucrose-derived malate; Udvardi et al. 1988) and to transport the products of symbiotic $\mathrm{N}_{2}$ fixation back to the plant. The young cells inside the emerging nodule become invaded by the "rhizobia", which now differentiate into $\mathrm{N}_{2}$-fixing bacteroids. Bacterial $\mathrm{N}_{2}$ fixation genes express the components of the nitrogenase enzyme complex (NifH, NifD, and NifK), that together with critical genes for regulation, iron and molybdenum supply, electron transport facilitate the conversion of atmospheric $\mathrm{N}_{2}$ into $\mathrm{NH}_{3}$ (ammonia) which in turn is assimilated within the nodule cell cytoplasm to glutamine. Glutamine in turn serves as the $\mathrm{N}$ donor for the subsequent 
synthesis of a complex set of amino acid and or $\mathrm{N}$ transport compounds (such as ureides in soybean, or glutamine and asparagine in temperate legumes; Peoples and Herridge 1990). Nodule development is regulated internally by an "autoregulation of nodulation" (AON) circuit (cf., Gresshoff et al. 2009; Reid et al. 2011) and externally by stress as well as nitrate (Carroll et al. 1985; Ferguson et al. 2010).

Overall the nitrogenase reaction associated with $\mathrm{N}_{2}$ fixation in the nodule is as follows:

$\mathrm{N}_{2}+8 \mathrm{H}^{+}+8 \mathrm{e}^{-}+16 \mathrm{ATP} \rightarrow 2 \mathrm{NH}_{3}+\mathrm{H}_{2}+16 \mathrm{ADP}+16 \mathrm{P}_{\mathrm{i}}$

One notes the large energy demand in electrons and ATP. This occurs through the action of oxidative phosphorylation under microaerobic conditions, requiring the red heme protein leghemoglobin to act as a limiting oxygen carrier to the $\mathrm{N}_{2^{-}}$ fixing and rapidly respiring bacteroids. As a result, the process of $\mathrm{N}_{2}$ fixation in legume nodules is generally considered to have much higher energy and $\mathrm{C}$ requirements for $\mathrm{N}$ assimilation than plants dependent upon $\mathrm{NO}_{3}{ }^{-}$ reduction for growth (Fig. 1; Atkins 1984; Kaschuk et al. 2009). However, conclusions about what this means with respect to $\mathrm{CO}_{2}$ losses from BNF are not so straightforward. Some experiments comparing below-ground losses of $\mathrm{CO}_{2}$ from the root systems of $\mathrm{N}_{2}$-fixing legumes with $\mathrm{NO}_{3}{ }^{-}$-fed legumes have found similar respiratory losses (e.g., 22-23 g $\mathrm{CO}_{2}$ per gram of $\mathrm{N}$ assimilated; Minchin and Pate 1973), while other studies have reported that between $10 \mathrm{~g}$ (Pate et al. 1979) and $20 \mathrm{~g}$ more $\mathrm{CO}_{2}$ to be respired per gram of $\mathrm{N}$ accumulated by nodulated legumes than by plants dependent upon $\mathrm{NO}_{3}{ }^{-}$for growth (Minchin et al. 1980; Finke et al. 1982). This range of estimates of additional respiratory losses due to BNF reflects key differences between species in the main site of $\mathrm{NO}_{3}{ }^{-}$reduction. The smallest differences between the $\mathrm{C}$ costs of $\mathrm{N}_{2}$ fixation and $\mathrm{NO}_{3}{ }^{-}$uptake and reduction by $\mathrm{N}$-fertilized plants occurred where much of the incoming $\mathrm{NO}_{3}{ }^{-}$was reduced in roots (field pea and white lupin, Lupinus albus) rather than in leaves (soybean and cowpea, Vigna unguiculata; Atkins 1984).

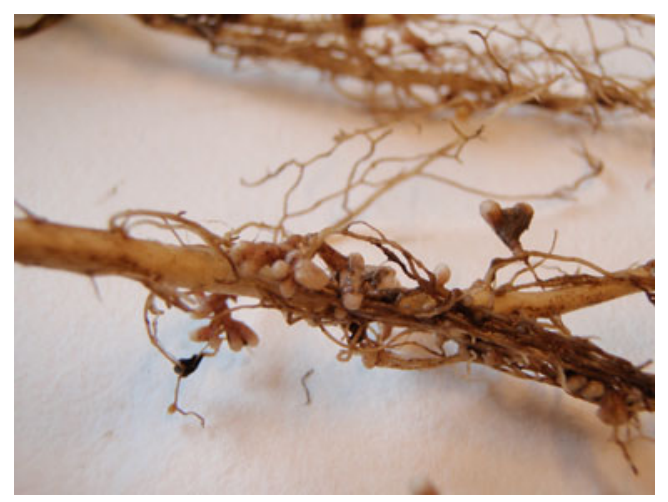

Fig. 1 Nodules on alfalfa root fixing atmospheric nitrogen. Photo: T. Råberg, SLU
Current global estimates of annual amounts of $\mathrm{N}_{2}$ fixed by agricultural legumes range between 33 and $46 \mathrm{Tg} \mathrm{N}$ (Herridge et al. 2008). Assuming that the $\mathrm{N}_{2}$ fixation process respires on average $10 \mathrm{~g}$ more $\mathrm{CO}_{2}$ from a legume's nodulated root system for every gram of $\mathrm{N}$ assimilated than plants utilizing fertilizer or soil $\mathrm{N}$ for growth, then between 350 and $500 \mathrm{Tg}$ of additional $\mathrm{CO}_{2}$ might be respired from the nodulated roots of legumes each year as a direct result of BNF.

Conclusions Globally, the amount of $\mathrm{CO}_{2}$ respired from the root systems of $\mathrm{N}_{2}$-fixing legumes could be comparable to, or higher than, the $\mathrm{CO}_{2}$ generated during $\mathrm{N}$-fertilizer production. However, the $\mathrm{CO}_{2}$ respired from the nodulated roots of legumes originated from the atmosphere via photosynthesis, so any of the $\mathrm{CO}_{2}$ that was not subsequently recaptured by the plant and eventually escaped from the legume canopy to the atmosphere would essentially be $\mathrm{C}$ neutral. By contrast, all the $\mathrm{CO}_{2}$ released during the synthesis of fertilizer $\mathrm{N}$ would be derived from fossil energy and represents a net contribution to atmospheric concentrations of $\mathrm{CO}_{2}$.

\subsection{2 $\mathrm{N}_{2} \mathrm{O}$ emissions}

About $5 \%$ of the total atmospheric greenhouse effect is attributed to $\mathrm{N}_{2} \mathrm{O}$ of which $60 \%$ to $70 \%$ of the annual global anthropogenic emissions have been calculated to come from animal and crop production (Mosier 2001; IPCC 2007). While $\mathrm{N}_{2} \mathrm{O}$ can be generated in the process of nitrification where nitrite is converted to $\mathrm{NO}_{3}{ }^{-}, \mathrm{N}_{2} \mathrm{O}$ losses as the result of denitrification are generally considered to be the more important source in most cropping and pasture systems (Rochester 2003; Peoples et al. 2004b; Soussana et al. 2010). Denitrification occurs when the soil is very moist and $\mathrm{O}_{2}$ supply is restricted, a suitable mineralizable organic $\mathrm{C}$ is present to be used as an energy source by denitifying microbes, and there are high concentrations of $\mathrm{NO}_{3}{ }^{-}$ (Peoples et al. 2004b; Stehfest and Bouwman 2006). Many species of soil bacteria are able to survive in anoxic conditions by using the denitrification process. Essentially, $\mathrm{NO}_{3}{ }^{-}$is substituted for $\mathrm{O}_{2}$ as a respiratory electron acceptor; the $\mathrm{NO}_{3}{ }^{-}$is reduced to nitrite and in sequence to $\mathrm{N}_{2} \mathrm{O}$ and $\mathrm{N}_{2}$. The bulk of the gaseous losses will be as $\mathrm{N}_{2}$, but the small proportion of the total emissions in the form of $\mathrm{N}_{2} \mathrm{O}$ (i.e., the ratio of $\mathrm{N}_{2} \mathrm{O} / \mathrm{N}_{2}$ ) can be affected by many different variables such as $\mathrm{N}$ application rate, soil organic C content, soil pH, and texture (Rochester 2003; Stehfest and Bouwman 2006; Peoples et al. 2009b). This illustrates the potential difficulty in reliably measuring or predicting specific losses of $\mathrm{N}_{2} \mathrm{O}$ from what is essentially a very complex, transient, and variable process. 
The IPCC (2006) suggested that for every $100 \mathrm{~kg}$ of fertilizer $\mathrm{N}$ added to the soil, on average $1.0 \mathrm{~kg}$ of $\mathrm{N}$ can be expected to be emitted as $\mathrm{N}_{2} \mathrm{O}$. As a GHG, $\mathrm{N}_{2} \mathrm{O}$ absorbs approximately 300 times as much infra-red radiation per kilogram as $\mathrm{CO}_{2}$ (Table 1), and since an emission of $1.0 \mathrm{~kg}$ $\mathrm{N}_{2} \mathrm{O}-\mathrm{N}$ equates to $1.57 \mathrm{~kg} \mathrm{~N}_{2} \mathrm{O}$ gas, the impact of every kilogram of $\mathrm{N}_{2} \mathrm{O}-\mathrm{N}$ released would be equivalent to around $470 \mathrm{~kg} \mathrm{CO}_{2}$. In addition to this amount, the IPCC includes further sources of $\mathrm{N}_{2} \mathrm{O}$ as $1.0 \%$ of the $\mathrm{N}$ deposited on the soil surface as residues (IPCC 2006). For many years, the IPCC reference manual (IPCC 1996) and the good practice guide for inventories (IPCC 2000) (erroneously) considered $1.25 \mathrm{~kg}$ of $\mathrm{N}_{2} \mathrm{O}-\mathrm{N}$ to be emitted for every $100 \mathrm{~kg}$ of biologically fixed $\mathrm{N}_{2}$. In other words, if BNF by legumes was responsible for emissions from the soil (rhizosphere) or from the nodules of this magnitude during growth, with subsequent additional losses when organic $\mathrm{N}$ in above-ground and below-ground legumes residues were mineralized, then legumes would be no more favorable than $\mathrm{N}$ fertilizer in terms of $\mathrm{GHG}$ emissions. Although the recent IPCC publications no longer includes $\mathrm{BNF}$ as a source of $\mathrm{N}_{2} \mathrm{O}$ (IPCC 2006), some countries around the world continue to utilize the former recommendations. The following sections review $\mathrm{N}_{2} \mathrm{O}$ emissions both during a legume's growth cycle, and subsequently from legume residues, and compare the magnitude of these $\mathrm{N}_{2} \mathrm{O}$ losses with fertilized systems.

\subsection{3 $\mathrm{N}_{2} \mathrm{O}$ emissions from legume and $\mathrm{N}$-fertilized systems}

The range of field-based measures of $\mathrm{N}_{2} \mathrm{O}$ emissions detected in different legume and $\mathrm{N}$-fertilized cropping and pasture systems are exceptionally wide (Table 2; see also

Table 2 Examples of total $\mathrm{N}_{2} \mathrm{O}$ emissions from field-grown legumes, $\mathrm{N}$ fertilized grass pastures and crops, or un-fertilized soils in North and South America, Europe, South Asia, East Asia, Australia, and New Zealand

\begin{tabular}{|c|c|c|c|}
\hline \multirow[t]{2}{*}{ Category and species } & \multirow[t]{2}{*}{ Number of site-years } & \multicolumn{2}{|c|}{ Total $\mathrm{N}_{2} \mathrm{O}$ emission per growing season or year $\left(\mathrm{kg} \mathrm{N}_{2} \mathrm{O}-\mathrm{N} \mathrm{ha}^{-1}\right)$} \\
\hline & & Range & Mean \\
\hline \multicolumn{4}{|l|}{ Pure legume stands ${ }^{\mathrm{a}}$} \\
\hline Alfalfa & 14 & $0.67-4.57$ & 1.99 \\
\hline White clover & 3 & $0.50-0.90$ & 0.79 \\
\hline \multicolumn{4}{|l|}{ Mixed pasture sward ${ }^{\mathrm{a}}$} \\
\hline Grass-clover & 8 & $0.10-1.30$ & 0.54 \\
\hline \multicolumn{4}{|l|}{ Legume crops ${ }^{\mathrm{a}}$} \\
\hline Faba bean & 1 & - & 0.41 \\
\hline Lupin & 1 & - & 0.05 \\
\hline Chickpea & 5 & $0.03-0.16$ & 0.06 \\
\hline Field pea & 6 & $0.38-1.73$ & 0.65 \\
\hline Soybean & 33 & $0.29-7.09$ & 1.58 \\
\hline Mean of all legumes & 71 & & 1.29 \\
\hline \multicolumn{4}{|l|}{$\mathrm{N}$-fertilized pasture ${ }^{\mathrm{b}}$} \\
\hline Grass & 19 & $0.3-18.16$ & 4.49 \\
\hline \multicolumn{4}{|l|}{$\mathrm{N}$-fertilized crops ${ }^{\mathrm{b}}$} \\
\hline Wheat & 18 & $0.09-8.57$ & 2.73 \\
\hline Maize & 22 & $0.16-12.67$ & 2.72 \\
\hline Canola & 8 & $0.13-8.60$ & 2.65 \\
\hline Mean of fertilized systems & 67 & & 3.22 \\
\hline \multicolumn{4}{|l|}{ Soil $^{c}$} \\
\hline No $\mathrm{N}$ fertilizer or legume & 33 & $0.03-4.80$ & 1.20 \\
\hline
\end{tabular}

Collated from the data presented by Ruz-Jerez et al. (1994); Bouwman (1996); Wagner-Riddle et al. (1997); Hénault et al. (1998); Kamp et al. (1998); Mahmood et al. (1998); Teira-Esmatges et al. (1998); Goossens et al. (2001); Aulakh et al. (2001); Rochette and Janzen (2005); Parkin and Kaspar (2006); Jones et al. (2007); Barton et al. (2008); Ciampitti et al. (2008); Chen et al. (2008); Barton et al. (2010); Schwenke et al. (2010); Barton et al. (2011), and includes unpublished data of Morrison et al. (unpublished data)

${ }^{a}$ Data come from systems where either no $\mathrm{N}$ fertilizer was used, or legumes were supplied with just $5 \mathrm{~kg}$ fertilizer-N ha ${ }^{-1}$ as "starter $\mathrm{N}^{\text {" at }}$ sowing, except for two experiments with grass-clover pastures and three soybean studies where $35-44 \mathrm{~kg}$ fertilizer-N ha ${ }^{-1}$ had been applied

${ }^{\mathrm{b}}$ Data have been restricted to trials where only $\mathrm{N}$ fertilizer was used. Treatments that included applications of animal manures have been excluded. Emissions from grasslands include both grazed and mown systems

${ }^{\mathrm{c}}$ Includes data from either unplanted soils or non-legume species were no $\mathrm{N}$ fertilizer was applied 
reviews by Bouwman 1996; Rochette and Janzen 2005). This is consistent with the large number of climatic, soil, and management variables known to influence the denitrification rate, and the amount of $\mathrm{N}_{2} \mathrm{O}$ emitted (Rochester 2003; Jones et al. 2007; Peoples et al. 2009b), and reflects the data having been derived from many unrelated experiments undertaken in a diverse range of farming systems from different environments and soil types around the world receiving vastly different amounts of $\mathrm{N}$. While it is clear from Table 2 that sizeable losses of $\mathrm{N}_{2} \mathrm{O}$ can occur from soil from under legume-based pastures and crops, the origin of this $\mathrm{N}_{2} \mathrm{O}$ cannot always be conclusively identified since many experiments do not include controls to quantify background soil emissions. Where appropriate controls have been included within the experimental design, the losses of $\mathrm{N}_{2} \mathrm{O}$ from soil have commonly not differed significantly from the legume treatment (e.g., Kilian and Werner 1996; Rochette et al. 2004; Ciampitti et al. 2008; Barton et al. 2011). This general observation is also supported when the measures of total $\mathrm{N}_{2} \mathrm{O}$ emissions from legume systems are averaged across all experiments and legume species $(1.29 \mathrm{~kg}$ $\mathrm{N}_{2} \mathrm{O}-\mathrm{N}$ ha ${ }^{-1}$, calculated from 71 site-years of data; Table 2) are compared to the equivalent mean data for unfertilized non-legume crops or un-planted soil (mean of $1.20 \mathrm{~kg} \mathrm{~N}_{2} \mathrm{O}$ $\mathrm{N} \mathrm{ha}{ }^{-1}$, calculated from 33 site-years of data; Table 2).

When considered in its entirety, the data of Table 2 suggest that while total $\mathrm{N}_{2} \mathrm{O}$ emissions during legume growth (Table 2) can be similar to N-fertilized systems, more often the $\mathrm{N}_{2} \mathrm{O}$ losses from soils under legumes tend to be lower than $\mathrm{N}_{2} \mathrm{O}$ fluxes from fertilized grasslands and non-legume crops (mean of $3.22 \mathrm{~kg} \mathrm{~N}_{2} \mathrm{O}-\mathrm{N} \mathrm{ha}{ }^{-1}$, calculated from 67 site-years of data; Table 2). This is illustrated in the experimental data presented in Table 3. The Brazilian study in Table 3 showed that the $\mathrm{N}_{2} \mathrm{O}$ emissions from a soybean-vetch (Vicia spp.) sequence were similar to $\mathrm{N}_{2} \mathrm{O}$ fluxes measured from cereal-only systems receiving relatively low rates of $\mathrm{N}$ fertilizer $\left(45-60 \mathrm{~kg} \mathrm{Nha}^{-1}\right.$ ) over two consecutive years of experimentation. The USA example provided in Table 3 on the other hand indicated that $\mathrm{N}_{2} \mathrm{O}$ emissions were considerably lower from soybean than from soil under the $\mathrm{N}$-fertilized maize crop in both years of the trial where more commercial rates of $\mathrm{N}$ fertilizer $(215 \mathrm{~kg} \mathrm{~N}$ $\mathrm{ha}^{-1}$ ) had been supplied. Large peaks in $\mathrm{N}_{2} \mathrm{O}$ fluxes also seem to be a feature of $\mathrm{N}$-fertilized pastures, particularly immediately following applications of $\mathrm{N}$ fertilizers (Jones et al. 2007; Soussana et al. 2010; Klumpp et al. 2011). As a consequence, total $\mathrm{N}_{2} \mathrm{O}$ losses from heavily $\mathrm{N}$-fertilized grasslands can be up to 4-fold higher than measured from unfertilized legume-grass pastures included in the same experiment (Ruz-Jerez et al. 1994).

The original assertion that BNF could be an important source of $\mathrm{N}_{2} \mathrm{O}$ emissions during legume growth seems to be based on reviews of the literature by Bouwman (1996) which included the results of studies undertaken in the 1980s where relatively high emissions had been recorded with legumes. There had also been some supporting experimental evidence that the process of BNF could give rise to $\mathrm{N}_{2} \mathrm{O}$ since strains of different species of rhizobia had been demonstrated to possess nitrate and nitrite reductase and were capable of denitrifying $\mathrm{NO}_{3}{ }^{-}$to $\mathrm{N}_{2} \mathrm{O}$ in vitro in the free-living form, in legume root nodules, or as isolated bacteroids (e.g., O'Hara and Daniel 1985; van Berkum and Keyser 1985; Smith and Smith 1986). However, subsequent studies examining different strains and species of rhizobia have indicated that the capacity of rhizobia to produce large amounts of $\mathrm{N}_{2} \mathrm{O}$ in anaerobic liquid medium amended with $\mathrm{NO}_{3}{ }^{-}$is very variable, and many strains produce only trace quantities under the same conditions (e.g., Table 4; Breitenbeck and Bremner 1989; Garcia-Plazaola et al. 1993; Rosen et al. 1996; Zhong et al. 2009).

Table 3 Measurements of $\mathrm{N}_{2} \mathrm{O}$ emissions for different cropping sequences over two consecutive years in Brazil (Jantalia et al. 2008) and the USA (Parkin and Kaspar 2006)

\begin{tabular}{|c|c|c|c|c|c|}
\hline Crop(s) in 2003 & $\begin{array}{l}\mathrm{N} \text { fertilizer applied } \\
\left(\mathrm{kg} \mathrm{Nha}^{-1}\right)\end{array}$ & $\begin{array}{l}\mathrm{N}_{2} \mathrm{O} \text { emissions } \\
\left(\mathrm{kg} \mathrm{N}_{2} \mathrm{O}-\mathrm{N} \mathrm{ha}^{-1}\right)\end{array}$ & Crop(s) in 2004 & $\begin{array}{l}\mathrm{N} \text { fertilizer applied } \\
\left(\mathrm{kg} \mathrm{Nha}^{-1}\right)\end{array}$ & $\begin{array}{l}\mathrm{N}_{2} \mathrm{O} \text { emissions } \\
\left(\mathrm{kg} \mathrm{N}_{2} \mathrm{O}-\mathrm{N} \mathrm{ha}^{-1}\right)\end{array}$ \\
\hline \multicolumn{6}{|l|}{ Brazil } \\
\hline Soybean-wheat & $\begin{array}{l}0 \text { (soybean) } \\
45 \text { (wheat) }\end{array}$ & $0.81 \mathrm{a}$ & Soybean-wheat & $\begin{array}{l}0 \text { (soybean) } \\
45 \text { (wheat) }\end{array}$ & $0.64 \mathrm{a}$ \\
\hline Soybean-vetch & 0 & $0.73 \mathrm{a}$ & Sorghum-wheat & $\begin{array}{l}60 \text { (sorghum) } \\
45 \text { (wheat) }\end{array}$ & $0.66 \mathrm{a}$ \\
\hline Maize-wheat & $\begin{array}{l}0 \text { (maize) } \\
45 \text { (wheat) }\end{array}$ & $0.83 a$ & Soybean-vetch & 0 & $0.68 \mathrm{a}$ \\
\hline \multicolumn{6}{|l|}{ USA } \\
\hline Soybean & 44 & $2.4 \mathrm{~b}$ & Maize & 215 & $12.7 \mathrm{a}$ \\
\hline Maize & 215 & $8.6 \mathrm{a}$ & Soybean & 44 & $7.1 \mathrm{~b}$ \\
\hline
\end{tabular}

Data have been averaged over several tillage systems. For each experiment and year, values followed by the same letter are not significantly different $(P<0.05)$ 
Table 4 Nitrous oxide fluxes normalized by the optical density (o.d.) of growth medium of several Bradyrhizobium spp. strains recommended for various grain and forage legumes (Alves et al., unpublished data)

\begin{tabular}{llcc}
\hline Bradyrhizobium strains & Legume host species & Optical density & $\mathrm{N}_{2} \mathrm{O}$ flux $\left(\mu \mathrm{mol} \mathrm{N} \mathrm{O} \mathrm{h}^{-1}\right.$ o.d. $\left.^{-1}\right)$ \\
\hline BR 446 & Stylosanthes sp. & 0.87 & 1.13 \\
BR 2003/2811 (mixture) & Crotalaria sp. & 0.72 & 0.002 \\
BR 2407 & Dolichos lablab & 0.69 & 0.001 \\
BR 85 (CPAC 7) & Glycine max & 0.86 & 0.02 \\
BR 86 (CPAC 15) & Glycine max & 0.98 & 0.49 \\
BR 1435 & Arachis sp. & 0.59 & 0.42 \\
\hline
\end{tabular}

The results of several controlled-environment studies with soybean have also raised considerable doubt about the relative importance of contributions of $\mathrm{N}_{2} \mathrm{O}$ fluxes from the process of $\mathrm{N}_{2}$ fixation in legume systems. In one study $\mathrm{N}_{2} \mathrm{O}$ emissions from $\mathrm{N}_{2}$-fixing soybean was found to be low and statistically similar to a non-nodulating soybean line and unplanted pots of soil even though large quantities of $\mathrm{N}$ were fixed (Table 5). A second key study showed that $>90 \%$ of the total growing season emissions of $\mathrm{N}_{2} \mathrm{O}$ occurred between grain-filling and maturity, and it was proposed that this $\mathrm{N}_{2} \mathrm{O}$ was more likely to be the result of $\mathrm{N}$ released from the decaying nodules and roots in the rhizosphere than to have arisen from BNF (Yang and Cai 2005).

Very similar results were observed in soybean field experiments in both Canada (Fig. 2) and Argentina (Ciampitti et al. 2008). No significant differences in $\mathrm{N}_{2} \mathrm{O}$ emissions were detected in the Canadian investigation between the $\mathrm{N}_{2}$-fixing and non-fixing soybean isolines during seed-filling when rates of BNF would generally be expected to be highest (Zapata et al. 1987; Bergersen et al. 1989). Differences were only observed in the final stages of seed maturation and following grain harvest (Fig. 2). Almost $70 \%$ of the total $\mathrm{N}_{2} \mathrm{O}$ lost during soybean's growing season occurred in the period between grain-filling and grain maturity in both studies (Fig. 2; Ciampitti et al. 2008). In the Argentinean experiment, the peak in $\mathrm{N}_{2} \mathrm{O}$ emissions from the soybean plots also corresponded with a spike in $\mathrm{N}_{2} \mathrm{O}$ fluxes from the unplanted soil control plots implying that background soil factors were largely responsible for the generation of $\mathrm{N}_{2} \mathrm{O}$, not the presence of the legume (Ciampitti et al. 2008).

Further evidence that $\mathrm{N}_{2} \mathrm{O}$ emissions are unlikely to be directly linked to $\mathrm{BNF}$ comes from investigations by Jantalia et al. (2008) in Brazil where $\mathrm{N}_{2} \mathrm{O}$ fluxes were monitored in different double-cropping systems (i.e., one summer crop and one winter crop grown in each year) over two consecutive years (Table 3 ). In that study, the soybean in the soybean-wheat sequence fixed between 100 and $200 \mathrm{~kg} \mathrm{Nha}^{-1}$ in above-ground biomass, while in neighboring plots, the soybean-vetch sequence, the total amounts of $\mathrm{N}$ fixed by both legume crops represented 165 to $280 \mathrm{~kg} \mathrm{Nha}^{-1}$ (Jantalia et al. 2008). Yet despite the large inputs of fixed $\mathrm{N}$ by the legumes, their measured emissions of $\mathrm{N}_{2} \mathrm{O}$ were not significantly different from the $\mathrm{N}_{2} \mathrm{O}$ fluxes coming from maize--wheat or sorghum (Sorghum bicolor)wheat sequences receiving between 45 and $60 \mathrm{~kg}$ fertilizer $\mathrm{N}$ ha ${ }^{-1}$ (Table 3).

Inexplicably high $\mathrm{N}_{2} \mathrm{O}$ fluxes have sometimes been detected in legume studies (e.g., soybean in 2004, Table 3; see also alfalfa data presented by Rochette et al. 2004 and some experiments collated by Helgason et al. 2005). If these are not associated with BNF, then what is the origin of the elevated emissions of $\mathrm{N}_{2} \mathrm{O}$ ? Some of the measured fluxes of $\mathrm{N}_{2} \mathrm{O}$ from legume fields could include the denitrification of $\mathrm{NO}_{3}{ }^{-}$derived from sources such as unutilized $\mathrm{N}$ fertilizer from the preceding crop, and/or from the decomposition of the previous crops residues and other background soil sources. But since denitrification and the proportion of the denitrified $\mathrm{N}$ released as $\mathrm{N}_{2} \mathrm{O}$ tends to be

Table 5 Soybean shoot dry matter (DM) and $\mathrm{N}$ accumulation, and cumulative $\mathrm{N}_{2} \mathrm{O}$ emissions from soil over 64 days

\begin{tabular}{llll}
\hline Treatment & Shoot DM $\left(\mathrm{g} \mathrm{plant}^{-1}\right)$ & Shoot N $\left(\mathrm{g} \mathrm{N} \mathrm{plant}^{-1}\right)$ & $\mathrm{N}_{2} \mathrm{O}$ emission $\left(\mathrm{mg} \mathrm{N} \mathrm{pot}^{-1}\right)$ \\
\hline Bare soil & $\mathrm{NA}$ & $\mathrm{NA}$ & $0.54 \mathrm{a}$ \\
Soybean cv Conquista & $26.1 \mathrm{a}$ & $0.60 \mathrm{a}$ & $0.52 \mathrm{a}$ \\
Non-nod soybean cv T-201 & $2.25 \mathrm{~b}$ & $0.03 \mathrm{~b}$ & $0.67 \mathrm{a}$ \\
\hline
\end{tabular}

Pots containing $10 \mathrm{~kg}$ of Rhodic Ferralsol were either sown to a nodulating cultivar of soybean (Glycine max cv Conquista) double inoculated with two strains of Bradyrhizobium japonicum (SEMIA 5080 and SEMIA 5019), or to a non-nodulating soybean mutant (cv T-201). The amounts of $\mathrm{N}_{2}$ fixed by Conquista soybean were estimated to be $0.57 \mathrm{gN}$ plant $^{-1}$ by comparing the amounts of shoot $\mathrm{N}$ accumulated to the non-nodulating line. A bare soil treatment was included as a control (Alves et al., unpublished data). Means in the columns followed by the same letter are not statistically different at $P<0.05$ Tukey's test

$N A$ not applicable 


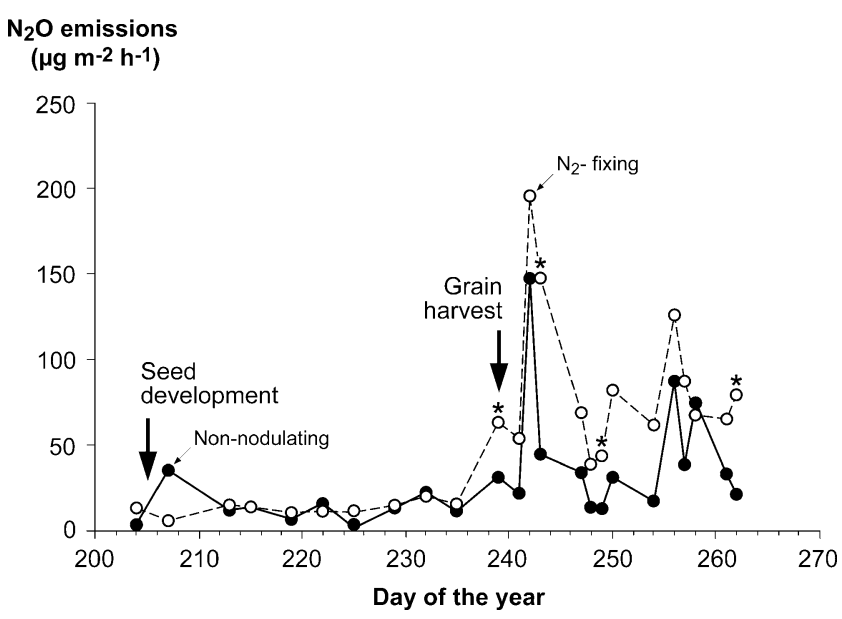

Fig. 2 Field measurements of $\mathrm{N}_{2} \mathrm{O}$ emissions from a trial at Ottawa, Ontario, Canada comparing non-nodulating (solid circle and line) and nodulated isolines (open circle and dashed line) of the soybean cultivar Presto during reproductive development and the immediate post-harvest period (Morrison et al., unpublished data). Determinations of $\mathrm{N}_{2} \mathrm{O}$ flux were achieved by placing chambers between the soybean rows every 3 or 4 days and sampling $\mathrm{N}_{2} \mathrm{O}$ in the gas head space over time. Each point represents the mean of four replicates, and an asterisk $(*)$ indicates samplings where significant $(P<0.05)$ differences in $\mathrm{N}_{2} \mathrm{O}$ emissions between nodulating and nonnodulating isolines were recorded. The arrows indicate the commencement of seed development and grain harvest. Cumulative estimates of $\mathrm{N}_{2} \mathrm{O}$ losses from the nodulated soybean line were calculated to be $1.2 \mathrm{~kg} \mathrm{~N}_{2} \mathrm{O}-\mathrm{N} \mathrm{ha}{ }^{-1}$ prior to the completion of seed development, $2.5 \mathrm{~kg} \mathrm{~N}_{2} \mathrm{O}-\mathrm{N}$ ha $^{-1}$ between seed development and grain maturity, and $3.8 \mathrm{~kg} \mathrm{~N}_{2} \mathrm{O}-\mathrm{N} \mathrm{ha}{ }^{-1}$ during the first 30 days after grain harvest

correlated with concentrations of soil $\mathrm{NO}_{3}{ }^{-}$(Wagner-Riddle and Thurtell 1998; Peoples et al. 2004b), denitrification of $\mathrm{NO}_{3}{ }^{-}$that is often observed to build up beneath $\mathrm{N}_{2}$-fixing legumes towards the end of the annual growing season (Peoples et al. 1995a; Chalk 1998) might also be a source of $\mathrm{N}_{2} \mathrm{O}$. Some of the inorganic $\mathrm{N}$ accumulating beneath legumes could represent "spared" soil $\mathrm{NO}_{3}{ }^{-}$not assimilated during legume growth due to the poor efficiency with which legume roots recover plant-available soil mineral $\mathrm{N}$ (Herridge et al. 1995; Chalk 1998; Jensen et al. 2010). Other potential sources include the rhizodeposition of $\mathrm{N}$ via exudates and secretions from living legume roots, or the mineralization of organic legume $\mathrm{N}$ released during the turnover of fine roots and nodules and from senesced leaf litter lost from the legume canopy during growth (Bergersen et al. 1989; Peoples et al. 1995a; Wichern et al. 2008). Intercropping of grain legumes with cereals may reduce soil mineral $\mathrm{N}$ levels during autumn and winter as well as the risk of $\mathrm{N}_{2} \mathrm{O}$ emission and leaching (Hauggaard-Nielsen et al. 2003, Fig. 3).

Shifts in the species composition of soil microbial populations and a high microbial diversity commonly detected in the legume rhizosphere (Lupwayi and Kennedy 2007; Osborne et al. 2010) could also be contributing factors to the high $\mathrm{N}_{2} \mathrm{O}$ flux since the release of readily metabolizable substrates into the legume rhizosphere stimulates microbial growth and activity and promotes oxygen consumption. This could conceivably create temporary anaerobic microsites in soil that would favor denitrification (Bertelsen and Jensen 1992; Lemke et al. 2007). There is also some evidence to suggest that the increased populations of microbes associated with the root systems of $\mathrm{N}_{2}$-fixing legumes include denitrifying bacteria (Zhong et al. 2009).

Conclusions Emissions of $\mathrm{N}_{2} \mathrm{O}$ tend to be lower under legumes than $\mathrm{N}$-fertilized crops and pastures, particularly when commercially relevant rates of $\mathrm{N}$ fertilizer are applied. This undoubtedly reflects differences in both the relative size of the $\mathrm{N}$ inputs and the concentrations of soil $\mathrm{NO}_{3}{ }^{-}$available to be denitrified. There is little evidence to support a direct association between $\mathrm{BNF}$ and $\mathrm{N}_{2} \mathrm{O}$ emissions from legume fields. While the source(s) of $\mathrm{N}$ responsible for the $\mathrm{N}_{2} \mathrm{O}$ emitted during a legume's growing season have not been identified, it is likely that the $\mathrm{N}_{2} \mathrm{O}$ is derived from the denitrification of $\mathrm{NO}_{3}{ }^{-}$that often accumulates in soil either as the result of inefficient recovery of $\mathrm{NO}_{3}{ }^{-}$by legume roots or the mineralization of labile sources of legume $\mathrm{N}$ released from the nodulated
Fig. 3 Intercropping of grain legumes and cereals enhances biomass yields, improves the use of resources, due to competitive interactions, and increases the yield stability compared to sole crop grain legumes. In addition, soil mineral $\mathrm{N}$ levels may be lower and the C-to-N ratio of crop residues more balanced than in the sole crop grain legume. Left: pea-barley intercrop; right: faba bean-spring wheat intercrop. Photos: H. Hauggaard-Nielsen, Risø DTU
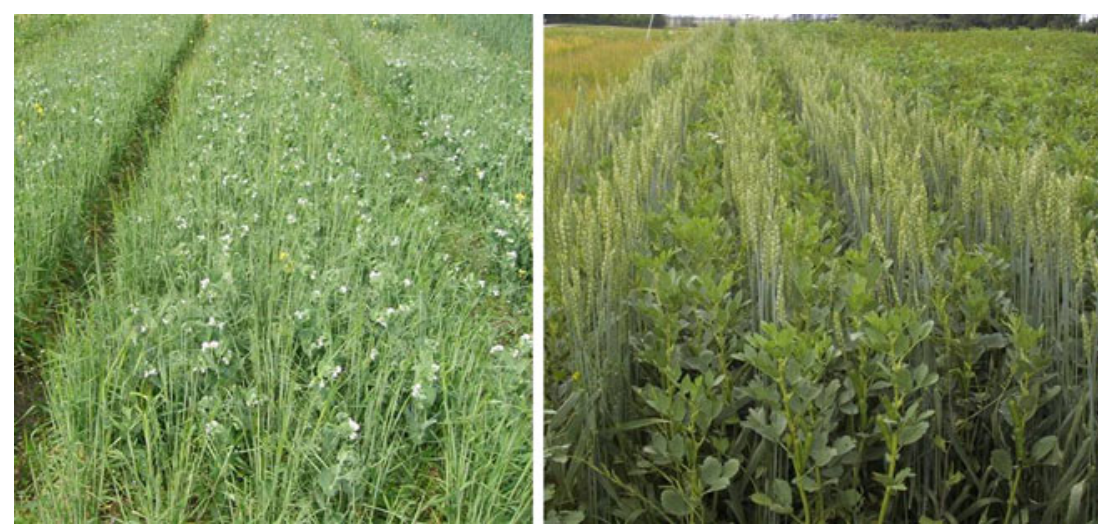
roots and fallen leaf material (Bertelsen and Jensen 1992; Rochette and Janzen 2005).

\subsection{4 $\mathrm{N}_{2} \mathrm{O}$ emissions derived from legume residues}

The decomposition and mineralization of organic $\mathrm{N}$ in legume residues into inorganic forms following a legume phase is a microbial-mediated process associated with the breakdown of organic compounds being used to provide the soil microbes with a C source for respiration and growth (Fillery 2001). Much of the simple organic $\mathrm{N}$ released from legume residues is rapidly assimilated (immobilized) by the soil microbial population (Bremer and van Kessel 1992; Murphy et al. 1998; Peoples et al. 2009b). Inorganic N (mineral Nammonium, $\mathrm{NH}_{4}{ }^{+}$, and $\mathrm{NO}_{3}{ }^{-}$) only accumulates in soil if the amounts of $\mathrm{N}$ released from residues exceed the $\mathrm{C}$-limited microbial requirement for $\mathrm{N}$ for growth. Since legume tissues tend to have higher $\mathrm{N}$ contents and lower $\mathrm{C} / \mathrm{N}$ ratios than non-leguminous material, legume residues are more likely to result in net mineralization and a build-up of inorganic $\mathrm{N}$ in soil (Peoples and Herridge 1990; Kumar and Goh 2000). Concentrations of inorganic $\mathrm{N}$ in field soils are generally observed to be higher when sowing a subsequent crop in a rotation if it follows a legume crop or pasture than a cereal (Chalk 1998; Fillery 2001; Jensen and Hauggaard-Nielsen 2003). This can often be related to the amounts of legume $\mathrm{N}$ accumulated during a pasture phase or the amounts of crop legume $\mathrm{N}$ remaining in residues following grain harvest (Evans et al. 2003; Peoples et al. 2001, 2004a).

Since legume residues provide a source of easily decomposable $\mathrm{C}$ substrate for denitrifying microorganisms, emissions of $\mathrm{N}_{2} \mathrm{O}$ could occur either during the process of nitrification of $\mathrm{N}$ derived from legume residues or as a result of the denitrification of the $\mathrm{NO}_{3}{ }^{-}$pool that subsequently builds up in the soil. In general terms, the susceptibility of $\mathrm{N}$ derived from legume residues to loss processes is determined by how well the release (supply) of mineralized $\mathrm{N}$ is synchronized with the demand for $\mathrm{N}$ by following crops (Crews and Peoples 2005).

The fate of legume or fertilizer $\mathrm{N}$ is often measured using ${ }^{15} \mathrm{~N}$-labeled materials. These studies indicate that while a much lower proportion of the $\mathrm{N}$ originally present in legume residues is usually taken up by a subsequent wheat, rice, or maize crop (on average 15-20\%; Peoples et al. 1995a; Fillery 2001; Peoples et al. 2009b) than from fertilizer (on average 30-40\%; Peoples et al. 1995a; Krupnik et al. 2004; Crews and Peoples 2005), considerably more legume $\mathrm{N}$ is retained in the soil system than fertilizer $\mathrm{N}(60 \%$ vs. $30 \%$, respectively; Crews and Peoples 2005; Peoples et al. 2009b). While the extent of losses will be influenced by whether the system is rainfed or irrigated, average losses from cereals appear to be in the order of $10-20 \%$ for legume $\mathrm{N}$ and 30
$40 \%$ for fertilizer (Peoples et al. 2004b, 2009b). Metaanalysis of ${ }^{15} \mathrm{~N}$ field experiments has shown that the extent of losses is driven by the size of the $\mathrm{N}$ inputs regardless of the source and has indicated that total losses of legume $\mathrm{N}$ tend to be less than from fertilizer when both are applied at rates of $<125 \mathrm{~kg} \mathrm{Nha}^{-1}$ (Gardner and Drinkwater 2009). While quite a lot may be known about total losses of legume or fertilizer $\mathrm{N}$, it is more difficult to generalize about denitrification as the pathway of $\mathrm{N}$ loss, or more specifically about how much of the losses from above- and below-ground legume residues might be in the form of $\mathrm{N}_{2} \mathrm{O}$.

The "window of asynchrony" between $\mathrm{N}$ supply and demand, and the period of highest risk for denitrification losses, is likely to be greatest in legume-based systems when a fallow period follows a legume and/or early in the subsequent growing season because either no plants are present to capture and utilize the generated $\mathrm{NO}_{3}{ }^{-}$or the demand for $\mathrm{N}$ by newly sown crops is small. Emissions of $\mathrm{N}_{2} \mathrm{O}$ were observed to rise immediately following soybean grain harvest in Canada and represented an average of $41 \mu \mathrm{g} \mathrm{N}_{2} \mathrm{O} \mathrm{m}^{-2} \mathrm{~h}^{-1}$ or a total of $3.8 \mathrm{~kg} \mathrm{~N}_{2} \mathrm{O}-\mathrm{N} \mathrm{ha}^{-1}$ over the 30 days of measurement (Fig. 2). Differences in $\mathrm{N}_{2} \mathrm{O}$ flux between the nodulated and non-nodulated soybean treatments during the post-harvest period in this particular experiment were attributed to decomposition of nodule $\mathrm{N}$ (see also the conclusions of Rochette and Janzen 2005). Similar data collected during the post-harvest summer-autumn fallow period (November-April) between crops in Western Australia in a drier environment on the other hand showed little evidence of elevated $\mathrm{N}_{2} \mathrm{O}$ emissions where relatively small amounts of senesced stubble from narrow-leafed lupin (Lupinus angustifolius) had been retained $[2.3 \mathrm{Mg}$ aboveground $\mathrm{DM} \mathrm{ha}^{-1}\left(1 \mathrm{Mg}=10^{6} \mathrm{~g}\right.$, or $\left.1 \mathrm{t}\right)$, containing $26 \mathrm{~kg} \mathrm{~N}$ $\mathrm{ha}^{-1}, \mathrm{C} / \mathrm{N}$ ratio $\left.=45\right]$ compared to a bare soil control $(0.07$ and $0.04 \mathrm{~kg} \mathrm{~N}_{2} \mathrm{O}-\mathrm{N} \mathrm{ha}^{-1}$, respectively; Barton et al. 2011). It should be acknowledged that for any mineralization of residues or denitrification to occur in the Mediterranean-type climate (wet winters and dry summers) of Western Australia would greatly depend upon the timing and intensity of summer storms, and there may be years when $\mathrm{N}_{2} \mathrm{O}$ emissions will be more likely during the fallow period between crops than others (Barton et al. 2008). The potential for post-harvest $\mathrm{N}_{2} \mathrm{O}$ emissions is probably greater in the summer-dominant rainfall region of the northern cropping zone of eastern Australia. Experimentation undertaken in northern New South Wales measured losses of $0.06 \mathrm{~kg} \mathrm{~N}_{2} \mathrm{O}$ $\mathrm{N} \mathrm{ha}^{-1}$ during the first 2 months of the summer fallow period after a chickpea crop (Schwenke et al. 2010, Fig. 4), while $0.24 \mathrm{~kg} \mathrm{~N}_{2} \mathrm{O}-\mathrm{N} \mathrm{ha}{ }^{-1}$ was emitted over the same period following a $\mathrm{N}$-fertilized canola treatment included in the same trial. Most of the fallow emissions in this particular study occurred during a week of continual rain when the trial plots received $>120 \mathrm{~mm}$ of rainfall (Schwenke et al. 2010). 


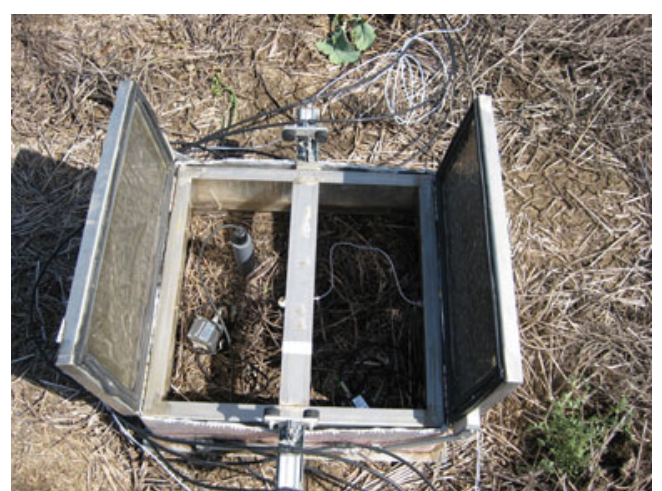

Fig. 4 Chamber used to quantify $\mathrm{N}_{2} \mathrm{O}$ emissions from legume residues. The lid of a chamber in one of the four replicates of each treatment automatically closes on a rotational basis each hour of the day to continually monitor changes in concentrations of $\mathrm{N}_{2} \mathrm{O}$ in the chamber headspace. Photo: M. B. Peoples, CSIRO

Another key period of risk for $\mathrm{N}$ losses from legume systems in the cool-temperate climates of the northern hemisphere occurs during winter and early spring thaw since high rates of nitrification can occur in cool wet soils (Magid et al. 2001), while any plant roots present will be unlikely to be actively assimilating the $\mathrm{NO}_{3}{ }^{-}$mineralized from legume residues (Jensen and Hauggaard-Nielsen 2003). Emissions of $\mathrm{N}_{2} \mathrm{O}$ collected from either lentil or field pea residues immediately following spring snow melt were not significantly different from neighboring wheat stubble plots in Saskatchewan $\left(0.1 \mathrm{~kg} \mathrm{~N}_{2} \mathrm{O}-\mathrm{N} \mathrm{ha}{ }^{-1}\right)$ and Alberta, Canada ( 0.4 to $0.6 \mathrm{~kg} \mathrm{~N}_{2} \mathrm{O}-\mathrm{N} \mathrm{ha}^{-1}$ ), suggesting that $\mathrm{N}_{2} \mathrm{O}$ emissions by crop legume residues remaining from the previous year can be negligible (Lemke et al. 2007). However, the situation was found to be very different elsewhere in Canada following the autumn termination and plough-down of $\mathrm{N}$ rich alfalfa biomass where significantly higher fluxes of $\mathrm{N}_{2} \mathrm{O}$ were measured during winter and early spring $(5.38 \mathrm{~kg}$ $\mathrm{N}_{2} \mathrm{O}-\mathrm{N} \mathrm{ha}{ }^{-1}$ ) than detected coming from a bare soil during the same period (2.84 $\mathrm{kg} \mathrm{N}_{2} \mathrm{O}-\mathrm{N} \mathrm{ha}{ }^{-1}$; Wagner-Riddle et al. 1997). There was also evidence that these elevated emissions may persist for up to 2 years after removal of the alfalfa stand (Wagner-Riddle and Thurtell 1998). By way of comparison, the initial losses of $\mathrm{N}_{2} \mathrm{O}$ following alfalfa plough-down over the winter-early spring period was more than 3-fold greater that the $\mathrm{N}_{2} \mathrm{O}$ emissions from barley, canola, or maize crops $\left(1.05-1.31 \mathrm{~kg} \mathrm{~N}_{2} \mathrm{O}-\mathrm{N} \mathrm{ha}^{-1}\right)$ that were subsequently grown in different treatment plots at the same experimental sites that were fertilized with between 75 and $100 \mathrm{~kg} \mathrm{Nha}^{-1}$ (Wagner-Riddle et al. 1997).

Another situation analogous to the alfalfa plough-down example that would be conducive to generating high concentrations of soil $\mathrm{NO}_{3}{ }^{-}$susceptible to denitrification losses occurs when fresh legume biomass is either greenmanured (i.e., either physically incorporated into soil or used as mulch) or brown-manured (killed prior to maturity with a knock-down herbicide). Certainly higher $\mathrm{N}_{2} \mathrm{O}$ emissions have been observed coming from soil under a maize crop in the UK where $3.9 \mathrm{Mg} \mathrm{ha}^{-1}$ of over-wintering faba bean foliage containing $180 \mathrm{~kg} \mathrm{Nha}^{-1}(\mathrm{C} / \mathrm{N}$ ratio=12) had been green-manured prior to sowing $\left(0.79 \mathrm{~kg} \mathrm{~N}_{2} \mathrm{O}-\right.$ $\mathrm{N} \mathrm{ha}^{-1}$ over 65 days) than detected coming from the nil residue control treatment $\left(0.23-0.31 \mathrm{~kg} \mathrm{~N}_{2} \mathrm{O}-\mathrm{N} \mathrm{ha}{ }^{-1}\right.$; Baggs et al. 2003). Fluxes of $\mathrm{N}_{2} \mathrm{O}$ during the growth of lowland (wetland/flooded) rice in India were also considerably higher from sesbania (Sesbania aculeate) greenmanured plots (11.5 $\mathrm{kg} \mathrm{N}_{2} \mathrm{O}-\mathrm{N}$ ha $^{-1}$ over 119 days) receiving $40 \mathrm{Mg} \mathrm{ha}{ }^{-1}$ of shoot material containing $176 \mathrm{~kg} \mathrm{Nha}^{-1}(\mathrm{C} / \mathrm{N}$ ratio $=18)$ than where $6 \mathrm{Mg} \mathrm{ha}^{-1}$ of wheat stubble containing $27 \mathrm{~kg} \mathrm{Nha}^{-1}(\mathrm{C} / \mathrm{N}$ ratio $=94)$ were either retained $\left(6.6 \mathrm{~kg} \mathrm{~N}_{2} \mathrm{O}-\mathrm{N} \mathrm{ha}^{-1}\right)$ or removed $(5.0 \mathrm{~kg}$ $\mathrm{N}_{2} \mathrm{O}-\mathrm{N} \mathrm{ha}{ }^{-1}$; Aulakh et al. 2001). While green-manuring may be a good strategy to economize (financially) on $\mathrm{N}$ fertilizer, it is clearly a risky practice with regards to GHG emissions. In the case of the study of Aulakh et al. (2001), losses of $\mathrm{N}_{2} \mathrm{O}$ from the green-manured plots were equivalent to where $120 \mathrm{~kg} \mathrm{Nha}^{-1}$ was supplied to rice as $\mathrm{N}$ fertilizer, although a lower proportion of the applied $\mathrm{N}$ was calculated to be lost as $\mathrm{N}_{2} \mathrm{O}$ from the sesbania mulch $(6.5 \%)$ than from the $\mathrm{N}$ fertilizer $(8.8 \%)$.

Conclusions There is a real risk of elevated $\mathrm{N}_{2} \mathrm{O}$ emissions from legume residues. Low $\mathrm{C} / \mathrm{N}$ ratio of leguminous material can potentially stimulate $\mathrm{N}_{2} \mathrm{O}$ losses as they are a source of $\mathrm{N}$ for rapid mineralization and nitrification, and legume residues provide a source of easily decomposable $\mathrm{C}$ substrate for microorganisms to support the denitrification of $\mathrm{NO}_{3}{ }^{-}$that accumulates in soil. Clearly, there are situations where large amounts of labile legume organic $\mathrm{N}$ is returned to soil such as when legume-based pastures have been terminated prior to cropping, or where legumes are used for green-manure. Under these conditions, $\mathrm{N}_{2} \mathrm{O}$ emissions can be comparable to, or greater than, where crops receive $\mathrm{N}$ fertilizer (Wagner-Riddle et al. 1997; Aulakh et al. 2001). However, the senesced, vegetative stubble that typically remains after grain harvest of legume crops is unlikely to represent a major source of $\mathrm{N}_{2} \mathrm{O}$ loss above normal background soil emissions (Lemke et al. 2007) since the quantities of organic $\mathrm{N}$ returned to the soil tend to be relatively small and the $\mathrm{C} / \mathrm{N}$ ratio of the residues are less favorable for rapid mineralization to build up high concentrations of soil $\mathrm{NO}_{3}{ }^{-}$(Kumar and Goh 2000; Fillery 2001; Peoples et al. 2009b).

\subsection{Comparisons of energy use by legume-based} and $\mathrm{N}$-fertilized systems

Fossil fuel is used in both legume and non-legume cropping and forage systems in the production of seed for sowing; by 
Table 6 Fossil energy consumed in pea, barley, and forage crops in Denmark and the amount of product dry matter (DM) harvested (Peoples et al. 2009b)

\begin{tabular}{|c|c|c|c|c|}
\hline Parameter $^{\mathrm{a}}$ & Pea & Barley & Grass-clover & Grass \\
\hline Direct energy in diesel use (MJ ha $\left.{ }^{-1}\right)$ & 3,320 & 3,400 & 3,940 & 4,880 \\
\hline $\mathrm{N}$ fertilizer $\left(\mathrm{kg} \mathrm{Nha}^{-1}\right)$ & 0 & 130 & 125 & 400 \\
\hline $\mathrm{N}$ fertilizer $\left(\mathrm{MJ} \mathrm{ha}{ }^{-1}\right)$ & 0 & 6,500 & 6,250 & 20,000 \\
\hline Seeds and non-N fertilizers ( $\mathrm{MJ} \mathrm{ha}^{-1}$ ) & 2,770 & 1,860 & Manure $^{\mathrm{b}}$ & Manure $^{b}$ \\
\hline Pesticides (MJ ha $\left.{ }^{-1}\right)$ & 900 & 900 & 50 & 50 \\
\hline Total fossil energy use (MJ ha $\left.{ }^{-1}\right)$ & $6,990(55 \%)$ & 12,660 & $10,240(41 \%)$ & 24,930 \\
\hline Harvested product ( $\mathrm{kg} \mathrm{DM} \mathrm{ha}{ }^{-1}$ ) & 6,000 & 8,000 & 7,700 & 11,700 \\
\hline Energy input $\left(\mathrm{MJ} \mathrm{kg} \mathrm{DM}^{-1}\right)$ & $1.16(73 \%)$ & 1.58 & $1.32(62 \%)$ & 2.13 \\
\hline
\end{tabular}

Values in parentheses represent energy use in legume systems expressed as a percentage of the energy used by the non-legume comparison

${ }^{a}$ Basis of calculations: diesel $=41 \mathrm{MJ} \mathrm{L}^{-1} ; \mathrm{N}$ fertilizer $=50 \mathrm{MJ} \mathrm{kg} \mathrm{N}{ }^{-1}$; pesticides $=300 \mathrm{MJ} \mathrm{kg}^{-1}$ active ingredient

${ }^{\mathrm{b}}$ Energy costs associated the collection and spreading of manures to forage crops are not included in the calculations, but were assumed to be similar for both the grass and the grass-clover mixture

on-farm machinery for tillage, sowing, and harvesting of agricultural produce; and in the manufacture, transport, and application of fertilizers and other agrichemical inputs used to either supplement crop nutritional requirements or for crop protection. A comprehensive comparison of the use of energy by field pea or barley (Hordeum vulgare) crops, and in grass-clover mixtures or pure grass systems in Denmark revealed that total energy costs were $55 \%$ and $41 \%$ lower in the legume cropping and forage systems, respectively (Table 6). The single most energy-expensive input was $\mathrm{N}$ fertilizer accounting for $51 \%$ of the total on-farm use of fossil energy for barley and $81 \%$ of the fossil energy for the grass forage crop (Table 6).

Lower total fossil energy use by legume production systems was also apparent when similar analyses were collated for a larger range of crop comparisons elsewhere in
Europe and in North America (Table 7). The production of field pea and faba bean crops in Switzerland required 25\% less energy than canola (oilseed rape, Brassica napus), 36\% less than wheat (Triticum aestivum) and barley, and 60\% less energy than maize (Zea mays) production (Table 7). In North America, field pea required 35\% less energy than flax (Linum usitatissimum) and 45-48\% less than wheat, while soybean required $39 \%$ less energy than maize (Table 7). Since dry matter (DM) production and grain yield by legumes tend to be lower than $\mathrm{N}$-fertilized crops, the differences in energy use between legume and nonlegume crops were markedly reduced, and in some instances may be little different, when calculated on the basis of fossil energy use per kilogram of DM of product harvested (Tables 6 and 7). Although it should be noted that if the data were reconsidered on a per kilogram

Table 7 Comparisons of the amounts of $\mathrm{N}$ fertilizer used and energy consumed in the production of a range of legume and non-legume grain crops, and the amount of product dry matter (DM) harvested in the cropping systems of Switzerland (Köpke and Nemecek 2010) and North America (Zentner et al. 2004; Rathke et al. 2007)

\begin{tabular}{|c|c|c|c|c|c|c|}
\hline \multirow{2}{*}{$\frac{\text { Parameter }}{\text { Switzerland }}$} & \multicolumn{6}{|l|}{ Crop } \\
\hline & Pea & Faba bean & Wheat & Barley & Canola & Maize \\
\hline $\mathrm{N}$ fertilizer applied $\left(\mathrm{kg} \mathrm{Nha}^{-1}\right)$ & 5 & 5 & 136 & 100 & 105 & 110 \\
\hline Total energy use $\left(\mathrm{MJ} \mathrm{ha}^{-1}\right)$ & 14,100 & 13,500 & 22,900 & 20,100 & 18,400 & 34,100 \\
\hline Harvested product $\left(\mathrm{kg} \mathrm{DM} \mathrm{ha}{ }^{-1}\right)$ & 3,340 & 3,290 & 5,461 & 5,803 & 2,926 & 7,980 \\
\hline Energy input (MJ kg DM $\left.{ }^{-1}\right)$ & 4.22 & 4.10 & 4.19 & 3.46 & 6.29 & 4.27 \\
\hline North America & Pea & Soybean & Spring wheat & Winter wheat & Flax & Maize \\
\hline $\mathrm{N}$ fertilizer applied $\left(\mathrm{kg} \mathrm{Nha}^{-1}\right)$ & 19 & 0 & 76 & 106 & 59 & 113 \\
\hline Total energy use $\left(\mathrm{MJ} \mathrm{ha}^{-1}\right)$ & 4,584 & 5,938 & 8,400 & 8,730 & 7,040 & 9,713 \\
\hline Harvested product (kg DM ha $\left.{ }^{-1}\right)$ & 2,504 & 2,350 & 2,446 & 2,519 & 1,800 & 6,470 \\
\hline Energy use efficiency $\left(\mathrm{MJ} \mathrm{kg} \mathrm{DM}^{-1}\right)$ & 1.83 & 2.53 & 3.43 & 3.46 & 3.91 & 1.50 \\
\hline
\end{tabular}

Data have been averaged across different tillage treatments 
grain crude protein produced, then the comparisons would be far more favorable for legumes (Köpke and Nemecek 2010).

Since legumes can convey significant benefits for following crops (Kirkegaard et al. 2008; Peoples et al. 2009a,b), calculations of energy demand on an individual crop basis such as depicted in Tables 6 and 7 will underestimate the wider implications of total energy consumption at a rotational level. Life cycle analyses (LCA) of cropping sequences with and without the inclusion of a legume found that fossil fuel energy use with legumes included was on average $12-30 \%$ lower per year compared to a rotation where legume crop(s) were not included in all but one of the four locations in Europe (Table 8), while they were an average 13-24\% lower for four locations in North America (Table 8). It was only in the low-input cropping system in Spain where the introduction of field pea had no real effect on energy use as little or no $\mathrm{N}$ fertilizer was applied to the sunflower (Helianthus annuus) crop it replaced, therefore no $\mathrm{N}$ fertilizer was saved (Nemecek et al. 2008). Presumably both sunflower and pea would also have had similar effects in reducing cereal root diseases and breaking pest and weed cycles (Kirkegaard et al. 2008).

The largest energy savings occurred where a legume crop was grown every second year (field pea and soybean in Switzerland, lentil, Lens culinaris, at Swift Current Saskatchewan, and soybean at Lincoln, Nebraska) rather than just once in the rotation (Table 4). Whether this intensity of legume use is a wise strategy remains to be seen given the increased risk of accelerating the build-up of legume diseases or the development of herbicide resistance by weeds.

Recently, the influence of introducing grain legumes into a cereal-based cropping system in Canada has been evaluated by including the $\mathrm{CO}_{2}$ equivalent emissions $\left(\mathrm{CO}_{2} \mathrm{e}\right)$ derived from GHG release associated with farming activities, in addition to direct energy costs to compare the
"C footprint" of different cropping sequences (Gan et al. 2011). Averaged across five site-years of data, the $C$ footprint of durum wheat grain produced in a cerealcereal-durum system was calculated to represent $0.42 \mathrm{~kg}$ $\mathrm{CO}_{2} \mathrm{e}$ per kilogram of grain harvested. This compared to estimates of $0.30 \mathrm{~kg} \mathrm{CO} \mathrm{CO}_{2} \mathrm{e}$ per kilogram of durum grain when the durum was preceded by a grain legume (chickpea, lentil, or pea) in the previous year. In other words, the $\mathrm{C}$ footprint was $28 \%$ lower than when the durum crop was grown following a cereal (Gan et al. 2011).

Conclusions The reduced energy use and lower $\mathrm{C}$ footprint resulting from growing legumes largely reflected the removal of the need to apply $\mathrm{N}$ fertilizer and the subsequently lower $\mathrm{N}$ fertilizer requirements for the crops grown following the legumes. However, the total energy balance was also assisted by a lower use of agrichemicals since the diversification of the cropping sequence reduced the incidence of cereal pathogens and pests and changed weed populations, although it should be noted that the overall impact of legumes on energy use was greatly diminished if comparisons with $\mathrm{N}$-fertilized systems were calculated on the basis of the amounts of biomass or grain produced.

\subsection{Soil carbon sequestration and land use change}

Soils contain large amounts of $\mathrm{C}$ in both inorganic and organic forms. Inorganic forms of $\mathrm{C}$ are derived from geologic or soil parent material sources and are usually present in soils as carbonates and bicarbonates. The amount of soil organic $\mathrm{C}$ (SOC) present in soil can represent from $<20$ to $>200 \mathrm{Mg} \mathrm{Cha}^{-1}$ in the top $30 \mathrm{~cm}$ of soil (Arrouays et al. 2001; Hoyle et al. 2011). Soil organic C exists in several different pools of varying size. Plant roots, fresh residues, living microorganisms, and macrofauna represent $<15 \%$ of the total SOC pool, while partially

Table 8 Comparisons of estimates of average annual energy use (MJ ha ${ }^{-1}$ per year) by rotations with (+) or without (-) the inclusion of a legume in the cropping sequence at four locations in Europe (Nemecek et al. 2008) and North America (Zentner et al. 2001, 2004; Rathke et al. 2007)

\begin{tabular}{|c|c|c|c|c|c|c|c|c|}
\hline \multirow{3}{*}{$\begin{array}{l}\text { Geographic region } \\
\text { Europe }\end{array}$} & \multicolumn{8}{|c|}{ Location and rotation with $(+)$ or without $(-)$ a legume crop } \\
\hline & \multicolumn{2}{|c|}{ Saxony-Anhalt, Germany } & \multicolumn{2}{|l|}{ Barrois, France } & \multicolumn{2}{|c|}{ Canton Vaud, Switzerland } & \multicolumn{2}{|c|}{ Castilla y Léon, Spain } \\
\hline & + & - & + & - & + & - & + & - \\
\hline Annual energy use & $21,100(86 \%)$ & 24,500 & $19,900(88 \%)$ & 22,500 & $21,900(69 \%)$ & 31,500 & $13,100(102 \%)$ & 12,800 \\
\hline \multirow[t]{2}{*}{ North America } & \multicolumn{2}{|c|}{ Saskatchewan, Canada $\# 1^{\mathrm{a}}$} & \multicolumn{2}{|c|}{ Saskatchewan, Canada $\# 2^{a}$} & \multicolumn{2}{|c|}{ Saskatchewan, Canada $\# 3^{\mathrm{a}}$} & \multicolumn{2}{|l|}{ Nebraska, USA } \\
\hline & + & - & + & - & + & - & + & - \\
\hline Annual energy use & $4,305(75 \%)$ & 5,699 & $7,704(86 \%)$ & 8,913 & $7,092(87 \%)$ & 8,151 & $7,773(80 \%)$ & 9,713 \\
\hline
\end{tabular}

Values in parentheses represent energy use in legume systems expressed as a percentage of the energy used by the non-legume comparison

${ }^{a}$ The Canadian data were derived from three locations in Saskatchewan, Canada: Swift current (site \#1; diesel fuel use converted to MJ on the basis of $41 \mathrm{MJ} \mathrm{L}^{-1}$, as described in Table 6), Tisdale (site \#2), and Indian Head (site \#3). Data represent the mean of several different tillages treatments 
decomposed plant residues, humus (the product of the breakdown of plant residues and soil microbes), and very resistant forms of organic $\mathrm{C}$ such as charcoal represent the balance (Dalal and Chan 2001; Hoyle et al. 2011).

While the atmosphere contains around $750 \mathrm{Pg}(1 \mathrm{Pg}=$ $10^{15} \mathrm{~g}$ which is equivalent to $1 \mathrm{Gt}$ ) of $\mathrm{C}$ as $\mathrm{CO}_{2}$, globally the top meter of soil stores approximately 1,500 $\mathrm{Pg}$ in SOC and 900-1,700 Pg as inorganic C, and exchanges $60 \mathrm{Pg} \mathrm{C}$ each year with the atmosphere (Eswaran et al. 1993). The sheer size of the SOC pool and the annual flux of $\mathrm{C}$ passing through the soil are two reasons why so much focus has been given to the possible role sequestering $\mathrm{C}$ in soil might play in mitigating GHG emissions (Lal 2004; Soussana et al. 2010).

The amount of $\mathrm{C}$ accumulated in a soil is dependent upon the balance between $\mathrm{C}$ inputs and losses. In the absence of the transport and incorporation of large amounts of offsite organic wastes or biochar, new $\mathrm{C}$ can only be introduced to the soil via photosynthesis by plants. Consequently, any farm management practice that enhances total plant production and the retention of plant shoot and root residues, and/or reduces $\mathrm{C}$ losses can theoretically contribute to increasing soil C content (Hoyle et al. 2011). There is also an upper limit to the annual $\mathrm{C}$ inputs in plant residues, particularly in rainfed agriculture, where the availability of water and nutrient supply constrains photosynthesis and plant productivity.

Losses of $\mathrm{C}$ from soil result from leaching of dissolved and particulate $\mathrm{C}$, wind and water erosion, and the microbial decomposition and associated mineralization processes that convert $\mathrm{C}$ in fresh plant residues and SOC into $\mathrm{CO}_{2}$ (Dalal and Chan 2001; Kindler et al. 2011). The rate of microbial decomposition is heavily influenced by climate (Christopher and Lal 2007) and soil texture, factors that provide physical protection for SOC (Soussana et al. 2004, 2010; Hoyle et al. 2011), the source of organic residues (Gregorich et al. 2001; Rochester 2011), and farming practices, such as cultivation that increases soil disturbance and exposes plant residues and SOC to microbial decomposition (Dalal and Chan 2001; Christopher and Lal 2007). Depending upon climatic conditions, between $50 \%$ and $75 \%$ of the $\mathrm{C}$ in plant residues can be expected to be respired as $\mathrm{CO}_{2}$ by microbes during the first year of decomposition (Hoyle et al. 2011).

Changes in land use could shift the relative balance between $\mathrm{C}$ inputs and losses in either direction depending on the nature of the change. All soils will eventually attain a dynamic equilibrium level when soil $\mathrm{C}$ gains equal soil $\mathrm{C}$ losses (i.e., a steady state when the rate of change in SOC is zero) which represents the upper limit of the amount of $\mathrm{C}$ that can be sequestered as defined by the inherent physiochemical properties of the different soil pools, and factors such as silt and clay content, clay mineralogy, and microaggregation (Soussana et al. 2004; Stewart et al.
2008; Chan et al. 2011). The following sections examine the potential impact that legumes and management can have on SOC.

\subsubsection{Legume effects on soil carbon sequestration}

In terms of mitigating emissions of $\mathrm{CO}_{2}$, the $\mathrm{C}$ sequestered in soil should ideally be stored in stable forms of SOC such as humus (Christopher and Lal 2007). Humus represents $40-60 \%$ of the SOC and is the main stable form of C that can be influenced by human activity. It may take decades before increases in humus resulting from changes in soil management or farm inputs can be reliably quantified (Hoyle et al. 2011). With the exception of charcoal/biochar, all the other forms of SOC are more labile than humus and decompose within months or years. Nutrients such as N, phosphorus (P), and sulfur (S) are tied up along with $\mathrm{C}$ in humus and SOC cannot be effectively sequestered unless adequate amounts of these nutrients are available (Williams and Donald 1957; Kirkby et al. 2011). There is evidence to suggest that humification is particularly limited by the availability of $\mathrm{N}$ (Christopher and Lal 2007). The elemental composition of SOC tends to be very similar in almost all soils (e.g., $\mathrm{C} / \mathrm{N}$ ratios depicted in Fig. 5; similar relationships for $\mathrm{SOC}$ in $\mathrm{C} / \mathrm{P}$ and $\mathrm{C} / \mathrm{S}$ ratios can be found in Cleveland and Liptzin 2007 and Kirkby et al. 2011). Around $80 \mathrm{~kg} \mathrm{~N}$ is associated with every megagram of organic $\mathrm{C}$ accumulated in soil (Fig. 5; Table 9). Since the C/ $\mathrm{N}$ ratios and amounts of $\mathrm{N}$ provided per megagram of $\mathrm{C}$ in legume residues are generally much closer to that of soil

\section{Total soil C (\%)}

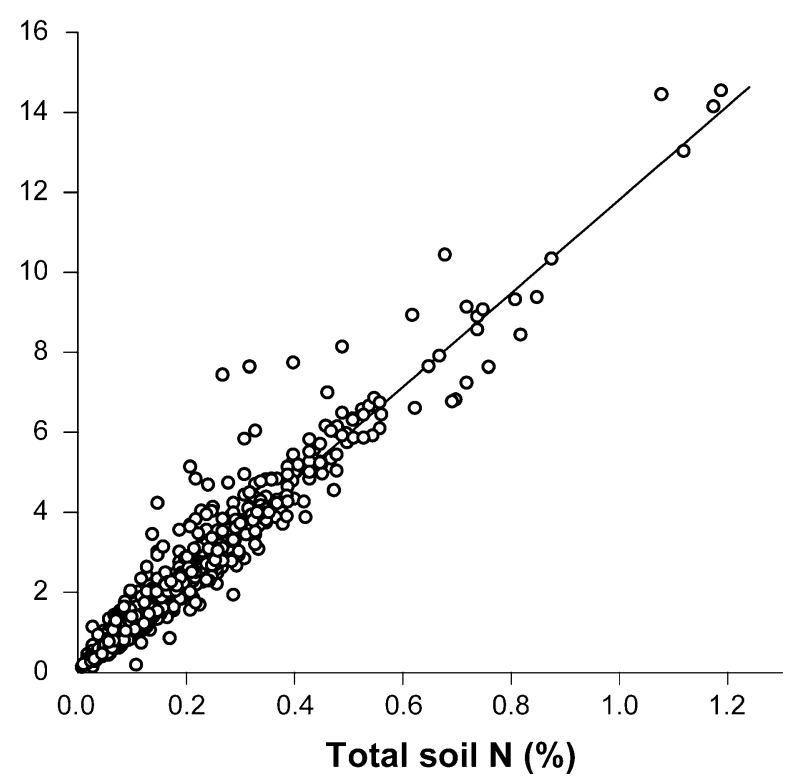

Fig. 5 Relationship between total soil $\mathrm{C}$ and $\mathrm{N}$ derived from 598 soils from around the world (modified from Kirkby et al. 2011). Linear regression: $\mathrm{C}=12(\mathrm{~N})-0.04\left(R^{2}=0.91\right)$ 
Table 9 Examples of the amounts $(\mathrm{kg})$ of $\mathrm{N}$ per $1,000 \mathrm{~kg}$ of $\mathrm{C}$ and the ratio of $\mathrm{C} / \mathrm{N}$ expressed on a mass basis of shoot residues of different plant species and selected components of the soil

${ }^{\mathrm{a} C o l l a t e d ~ f r o m ~ P e o p l e s ~ e t ~ a l . ~}$ (2009b), Rochester (2011), and unpublished data

${ }^{\mathrm{b}}$ Senesced shoot material from field-grown crops collected after grain harvest

${ }^{\mathrm{c}}$ Calculated from Fig. 2 and data presented by Cleveland and Liptzin 2007 and Kirkby et al. 2011

\begin{tabular}{|c|c|c|c|c|c|}
\hline \multicolumn{6}{|c|}{ Residues of different plant species ${ }^{a}$} \\
\hline Non-legumes & Wheat & Maize & Rice & Canola & Cotton \\
\hline Carbon $(\mathrm{C})$ & 1,000 & 1,000 & 1,000 & 1,000 & 1,000 \\
\hline Nitrogen $(\mathrm{N})$ & 19.6 & 21.4 & 9.5 & 23.8 & 38.5 \\
\hline $\mathrm{C} / \mathrm{N}$ ratio & $51: 1$ & $47: 1$ & $105: 1$ & $42: 1$ & $26: 1$ \\
\hline Legumes & Alfalfa & Vetch & Clover & Field peab & Faba bean \\
\hline Carbon (C) & 1,000 & 1,000 & 1,000 & 1,000 & 1,000 \\
\hline Nitrogen $(\mathrm{N})$ & 73.2 & 100 & 83.3 & 28.6 & 71.4 \\
\hline $\mathrm{C} / \mathrm{N}$ ratio & $14: 1$ & $10: 1$ & $12: 1$ & $35: 1$ & $14: 1$ \\
\hline \multicolumn{6}{|c|}{ Different soil components ${ }^{\mathrm{c}}$} \\
\hline & Microbial biomass & Fungi & Bacteria & Soil organic C & \\
\hline Carbon (C) & 1,000 & 1,000 & 1,000 & 1,000 & \\
\hline Nitrogen $(\mathrm{N})$ & 135 & 106 & 178.5 & 83.3 & \\
\hline $\mathrm{C} / \mathrm{N}$ ratio & $7: 1$ & $9: 1$ & $6: 1$ & $12: 1$ & \\
\hline
\end{tabular}

microorganisms and soil organic matter than non-legume species (Table 9), and leguminous organic matter tends to have higher $\mathrm{P}$ concentrations than other species (e.g., Pinkerton and Randall 1994), the inclusion of legumes in farming systems might be expected to be more conducive to $\mathrm{C}$ sequestration and the build-up of SOC over time.

\subsubsection{Pastures}

Despite the widespread utilization of mixed pastures in Europe based on ryegrass (Lolium multiflorum) and clovers (Trifolium spp.) there are relatively few quantitative studies of the impact of the legume introduction on soil $\mathrm{C}$ accumulation. Soussana et al. (2004) used models and data from a large survey of SOC under different land uses and soil types in France (Arrouays et al. 2001) to show that the conversion of short-term $\mathrm{N}$-fertilized grass leys to grasslegume mixtures could result in the accumulation of $10 \mathrm{Mg}$ $\mathrm{C} \mathrm{ha}^{-1}$ in the soil over a period of 20 years. Conant et al. (2001) in a review of soil $\mathrm{C}$ changes beneath temperate and tropical pastures also identified the inclusion of legumes as one of the many variables that can contribute to increased soil $\mathrm{C}$ stocks. Other factors found to influence the accumulation of SOC in pastures and rangelands include (1) climate and whether the pastures are rainfed or irrigated through effects on the net primary productivity of plants and $\mathrm{C}$ loss processes; (2) stocking rate and grazing management through defoliation and trampling effects on leaf area, photosynthesis, root biomass and soil microbial communities, and the impact of animal excreta on $\mathrm{C}$ and nutrient cycling; (3) the botanical composition of the pasture (i.e., the percentage of total pasture biomass present as grass or legumes); and (4) the age of the pasture and the initial state of the soil system since the rate of change in SOC tends to be greater where the initial soil C stocks are low (e.g., where SOC had been depleted by cropping) than where the soil is closer to its C equilibrium (Conant et al. 2001; Soussana et al. 2004; Klumpp et al. 2009; Soussana et al. 2010; Chan et al. 2011).

Conceptually, whether the forage legume is a perennial or annual could also be important. Although a long-term Australian study failed to detect major differences in the rate of SOC increase in the top $30 \mathrm{~cm}$ of soil between rainfed pastures containing the perennial legume alfalfa or annual clovers (Chan et al. 2011), alfalfa would be expected to have a higher potential for $\mathrm{C}$ allocation below $30 \mathrm{~cm}$ than clovers as a direct result of alfalfa's much deeper rooting systems (Angus et al. 2001; Peoples and Baldock 2001). Certainly, other investigations have reported significantly greater gains in SOC where alfalfa or other perennial species such as siratro (Macroptilium atropurpureum) or desmanthus (Desmanthus virgatus) were grown compared to where annual pasture or crop legumes had been used (Dalal et al. 1995; Armstrong et al. 1999; Whitbread et al. 2000; Young et al. 2009). Soil C stocks have also been found to be substantially higher $\left(130-134 \mathrm{Mg} \mathrm{ha}^{-1}, 0-70 \mathrm{~cm}\right)$ when maize was grown in rotation with alfalfa [undersown beneath oats (Avena sativa) and grown for 2.5 years in every 4 years] than under maize monoculture (109-115 $\mathrm{Mg} \mathrm{ha}^{-1}$; Gregorich et al. 2001). By employing a solid-state ${ }^{13} \mathrm{C}$ nuclear magnetic resonance analytical technique in this experiment, they demonstrated that $<15 \%$ of the $\mathrm{C}$ in maize residues was retained in soil compared to $>50 \%$ of the residue $\mathrm{C}$ contributed by the alfalfa and oats (Gregorich et al. 2001).

Rotations based on alternating periods of legume-based pastures and cropping are common in the dryland farming systems of Australia (Peoples and Baldock 2001; Kirkegaard et al. 2011). Even though SOC might accumulate under legume-based pastures, total $\mathrm{C}$ stocks will inevitably decline when the land is returned to cropping (Dalal et al. 1995; Chan 1997; Persson et al. 2008). In the long term, whether rotating pastures with crops results in net $\mathrm{C}$ sequestration, 
helps maintains SOC stocks, or simply slows the rate of loss of SOC compared to continuously cropped soils will be influenced by the prevailing climatic effects on $\mathrm{C}$ inputs and $\mathrm{C}$ loss processes, and the frequency or duration of the pasture phase (Grace et al. 1995; Dalal and Chan 2001; Young et al. 2009; Chan et al. 2011).

The potential for soil $\mathrm{C}$ sequestration is likely to be greatest in intensively managed permanent pastures and grasslands (Soussana et al. 2004). In the USA, Wright et al. (2004) reported that at low-grazing intensity, the SOC concentration $(0-15 \mathrm{~cm})$ under a long-term $\mathrm{N}$-fertilized (350 kg Nha ${ }^{-1}$ per year) Bermuda grass (Cynodon dactylon)/rye grass pasture in Texas increased by $39 \%$ over a 19 -year period, whereas SOC was increased by $67 \%$ under a Bermuda grass/clover (Trifolium sp.) mixture receiving no $\mathrm{N}$ fertilizer. Not only was there a more rapid increase in SOC by changing from a heavily N-fertilized pure grass pasture to a mixed grass/clover sward but this would also have reduced $\mathrm{N}_{2} \mathrm{O}$ emissions (Ruz-Jerez et al. 1994). Similar legume effects on SOC were observed when yellow-flowering alfalfa (M. sativa ssp. falcata) was interseeded into temperate grassland in the range lands of North Dakota (Mortensen et al. 2004) where average annual rates of soil $\mathrm{C}$ accumulation $(0-100 \mathrm{~cm})$ were increased by $1.56,0.65$ and $0.33 \mathrm{Mg} \mathrm{Cha}^{-1}$ per year 4,14 , and 36 years after alfalfa had been introduced, respectively. These data illustrate the fact that as time passes, $\mathrm{C}$ sequestration rates will decrease as a new equilibrium between $\mathrm{C}$ inputs and losses is attained.

In South America, grass-only pastures based on Brachiaria (Brachiaria decumbens, Brachiaria humidicola, and Brachiaria brizantha) have been shown to accumulate more SOC than was originally present under the native savanna vegetation (Fisher et al. 2007). The potential to further increase the rates of soil $\mathrm{C}$ sequestration with forage legumes has been demonstrated by Fisher et al. (1994) who found that in the eastern savanna of Colombia, soil $\mathrm{C}$ accumulation $(0-100 \mathrm{~cm})$ was increased by $7.8 \mathrm{Mg} \mathrm{ha}^{-1}$ per year where Arachis pintoi had been introduced into the sward, above that achieved by pure grass alone, despite the legume contributing only $20 \%$ of the total root biomass. Another study undertaken in the south of Bahia in Brazil showed that the introduction of Desmodium ovalifolium into a Brachiaria sward approximately doubled the rate of soil $\mathrm{C}$ accumulation $(0-100 \mathrm{~cm})$ from 0.66 to $1.17 \mathrm{Mg} \mathrm{C}$ $\mathrm{ha}^{-1}$ per year over a 9 -year period (Tarré et al. 2001).

In some cases, sub-optimal nutrition can severely limit the impact of legumes. A good example of this was in the acidic soils of southeastern Australia where the accumulation of SOC under permanent subterranean clover (Trifolium subterraneum) pastures was found to vary directly with the amount of superphosphate fertilizer applied (Williams and Donald 1957). It was proposed that the rate of build-up of organic matter was constrained by $\mathrm{P}$ and $\mathrm{S}$ deficiencies in the soils. Alleviating these constraints has also been shown to stimulate the productivity of subterranean clover and greatly increase the amounts of $\mathrm{N}_{2}$ fixed (Peoples et al. 1995b).

Conclusions There is evidence from many different regions and environments that SOC concentrations can be increased when legumes are included in pastures (e.g., Conant et al. 2001; Wright et al. 2004; Boddey et al. 2009; Chan et al. 2011). The impact of forage legumes appear to be greatest in permanent pastures and with perennial legume species. The effects of perennial legumes on SOC are associated with (1) lower losses of $\mathrm{C}$ from their organic residues than from annual legumes as a result of a lower soil water content maintained under perennials reducing microbial activity and respiratory losses of the organic $\mathrm{C}$ (Angus et al. 2001; Young et al. 2009), and (2) higher potential inputs of $\mathrm{C}$ due to the capacity of perennials to respond to rainfall and grow outside an annual's normal growing season (Peoples and Baldock 2001). Regardless of whether the legume is an annual or a perennial, a key factor contributing to the rate of SOC build-up will be the nutritional management of pastures (Williams and Donald 1957; Conant et al. 2001; Chan et al. 2011).

\subsubsection{Cropping sequences}

Cultivation and cropping leads to substantial losses of SOC principally via the decomposition of humus (Dalal and Chan 2001; Christopher and Lal 2007). The conversion of grassland to cropping has been reported to result in a decline in soil C stocks of between $25 \%$ and $43 \%$ at rates of up to $0.95 \mathrm{Mg} \mathrm{Cha}^{-1}$ per year (Soussana et al. 2004). Consequently, arable soils inevitably have lower levels of SOC than pastures (Arrouays et al. 2001). Until recently, there was a general consensus that a change from conventional tillage (CT) to reduced or zero tillage (ZT) systems that maintain at least $30 \%$ of the soil surface cover would lead to positive impacts on SOC in almost any cropping system as the tillage-induced losses of $\mathrm{C}$ would be avoided (Christopher and Lal 2007). This was challenged by Baker et al. (2007) who pointed out that in almost all the earlier studies of the effects of tillage the soil was sampled to $<30 \mathrm{~cm}$ depth only, often $<20 \mathrm{~cm}$. Evidence was presented that where soils had been sampled to greater depths (e.g., 80 or $100 \mathrm{~cm}$ ) more $\mathrm{C}$ was found at depth under $\mathrm{CT}$ and there was little or no difference between ZT and $\mathrm{CT}$ in total SOC down the soil profile (e.g., VandenBygaart et al. 2003). This led Baker et al. (2007) to conclude that the apparent accumulation of soil $\mathrm{C}$ observed under ZT compared to CT was largely an artifact of the sampling depth. 
Many of the early studies undertaken in both temperate and sub-tropical cropping systems that compared the interactions of tillage and the inclusion of legumes such as lupin, vetch, or cowpea in rotations also sampled the soil to $<30 \mathrm{~cm}$ depth and found that soil $\mathrm{C}$ concentrations were often considerably higher under ZT than under $\mathrm{CT}$ and that legume-cereal rotations tended to lose smaller amounts of SOC than continuous cereal cropping (e.g., Heenan et al. 1995; Bayer et al. 2000). Freixo et al. (2002) working in Brazil showed that even after 13 years of continuous wheat (winter)-soybean (summer) double-cropping systems (i.e., two crops every year), there were no significant differences in stocks of SOC between ZT and CT management when assessed to $40 \mathrm{~cm}$. Sisti et al. (2004) also found no significant difference between SOC stocks in continuous wheat-soybean under the different tillage systems (167 cf. $168 \mathrm{Mg} \mathrm{Cha}^{-1} 0-100 \mathrm{~cm}$ under CT and ZT, respectively; Fig. 6), although SOC stocks were approximately $10 \mathrm{Mg} \mathrm{C}$ $\mathrm{ha}^{-1}$ higher after 13 years of cropping where vetch had been included along with soybean in two different rotations as a winter green-manure crop before maize (178 and $179 \mathrm{Mg} \mathrm{Cha}^{-1}$ ), but only under ZT management. Where vetch was grown under CT, SOC was considerably lower (161 and $163 \mathrm{Mg} \mathrm{Cha}^{-1}$ ). Between $46 \%$ and $68 \%$ of the difference between SOC in the ZT and CT treatments that included vetch occurred below $30 \mathrm{~cm}$ (Sisti et al. 2004). The impact of vetch green-manure on SOC under ZT was confirmed in Brazil by Boddey et al. (2010) who found that SOC stocks under ZT $(0-100 \mathrm{~cm})$ were increased above that achieved with $\mathrm{CT}$ representing an average rate of change of between 0.48 and $1.53 \mathrm{Mg} \mathrm{Cha}^{-1}$ per year. Over $60 \%$ of this additional $\mathrm{C}$ was also found to be located below $30 \mathrm{~cm}$ depth. A positive impact of mucuna (Mucuna pruriens) cover-crops on $\mathrm{SOC}$ in the top $40 \mathrm{~cm}$ of soil was reported in cultivated maize systems in Benin, Africa (Barthès et al. 2004). In this case, the inclusion of mucuna cover-cropping resulted in an additional annual return of 11.9 $\mathrm{Mg} \mathrm{DM} \mathrm{ha}{ }^{-1}$ in shoot residues over and above that occurring in the more traditional unfertilized, cultivated maize monoculture. This represented increased inputs of

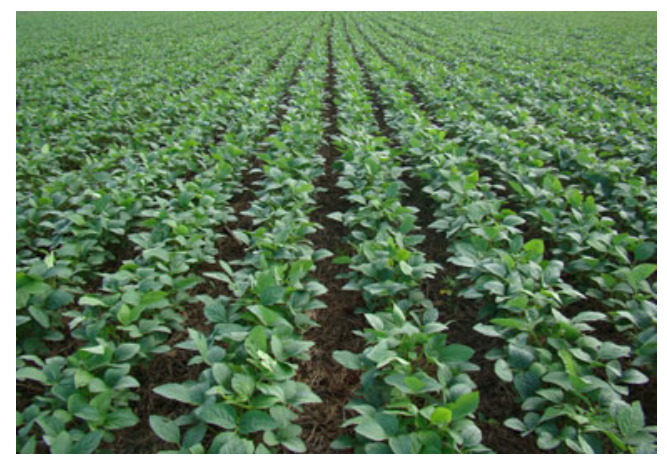

Fig. 6 Soybean cultivated on zero-till land. Photo: B. Alves, Embrapa organic $\mathrm{C}$ of $6.5 \mathrm{Mg} \mathrm{Cha}^{-1}$ per year, which contributed to an average change in SOC over 12 years equivalent to 1.3 $\mathrm{Mg} \mathrm{Cha}^{-1}$ per year (Barthès et al. 2004). Analyses of the ${ }^{13} \mathrm{C}$ signatures of soil and litter indicated that only $2 \%$ of the organic $\mathrm{C}$ was derived from maize residues compared to $57 \%$ from mucuna.

Rochester (2011), working in irrigated, minimum-tilled cotton (Gossypium hirsutum) cropping systems in Australia, found that after 10 years the SOC was $7.3 \mathrm{Mg} \mathrm{Cha}^{-1}$ higher to $90 \mathrm{~cm}$ (representing a 7\% increase) under cropping sequences that included either vetch green-manures or legume crops with relatively low $\mathrm{N}$ harvest indices (i.e., low ratio of grain $\mathrm{N} /$ total plant $\mathrm{N}$ ), such as faba bean, compared to non-legume alternatives (wheat-cotton, or continuous cotton). The rotations that included legumes returned $49 \%$ more stubble-C and $133 \%$ more stubble-N, and around $60 \%$ of the additional SOC was located below $30 \mathrm{~cm}$ (Rochester 2011).

The results of Diekow et al. (2005) indicate that the desired effects of legumes on SOC can also be achieved when legumes are intercropped with maize as cover-crops under ZT. After 17 years of ZT management, SOC $(0-108 \mathrm{~cm})$ ranged between 124 and $128 \mathrm{Mg} \mathrm{Cha}^{-1}$ under a continuous oatmaize sequence in either the absence or presence of $\mathrm{N}$ fertilizer (120-180 $\mathrm{kg} \mathrm{Nha}^{-1}$ ), but reached 141 to $149 \mathrm{Mg} \mathrm{C}$ $\mathrm{ha}^{-1}$ where lablab (Lablab purpureum) or pigeon pea (Cajanus cajan) were present as inter-crops without $\mathrm{N}$ fertilizer. This was not significantly different $(P<0.05)$ to measures of SOC under the native grassland 31 years earlier $\left(152 \mathrm{Mg} \mathrm{Cha}^{-1}\right)$.

Conclusions The cropping sequence studies described in this section demonstrated the potential contributions of $\mathrm{N}_{2}$ fixing legumes to SOC stocks under ZT or minimum tillage systems, although it was not always possible to discern from these studies whether the observed beneficial effects of legumes on SOC compared to continuous cereals resulted from a net increase in SOC stocks or simply reflected a slower decline in soil $\mathrm{C}$ reserves due to lower losses of organic C. An important discovery common to almost all the studies was that the impact of legumes on the accumulation of soil C under ZT was greatest in the subsoil below $30 \mathrm{~cm}$ depth. These observations differ from the original conclusions of Baker et al. (2007). Long-term experiments indicate that it can be difficult for legumes to influence SOC in CT systems (Freixo et al. 2002; Sisti et al. 2004; Boddey et al. 2010), but the data of Barthès et al. (2004) suggested that it might be possible to increase SOC under cultivation provided the inputs of legume organic $\mathrm{C}$ and $\mathrm{N}$ were greater than the increased losses of SOC stimulated by tillage.

It appears that the net N-balance of the system is a key driver of $\mathrm{C}$ stock changes in the soil. When a high $\mathrm{N}$ 
harvest index legume crop like soybean is the only legume present in a rotation, SOC stocks are not maintained because large quantities of $\mathrm{N}$ are exported from the field in the grain. By contrast, large amounts of organic $\mathrm{C}$ and $\mathrm{N}$ are returned to the soil where legume green-manures and cover-crops are utilized, or when legume crops with high vegetative residues are grown regularly.

\subsubsection{Woody perennial legumes}

Of all the land management options available, afforestation of land is often considered to result in the greatest $\mathrm{C}$ sequestration (Christopher and Lal 2007). Given the potential for fast-growing multipurpose legume trees and shrubs to accumulate biomass (e.g., Peoples et al. 1996), and to contribute substantial amounts of organic $\mathrm{C}$ and nutrients to soil through either leaf litter, the periodic harvest of foliage prunings for use as green-manure, or when grazed by ruminants, it is perhaps not surprising that woody perennial legumes have been considered a promising option to enhance SOC stocks while revegetating cleared land, degraded soils, or mining wastes (Thrall et al. 2005; Chaer et al. 2011; Radrizzani et al. 2011; Fig. 7).

It has been estimated that $27 \%$ of the total land area in South America is degraded. In Brazil alone, degraded land represents 236 million ha, approximately four times larger than the area dedicated to arable crops (Chaer et al. 2011). At least 50 million ha of the degraded areas in Brazil are former agricultural areas in the central savanna (Cerrado) region, which could potentially be reclaimed for food production. However, much of the remaining areas are located in the deforested hillsides in the Atlantic coastal region where there are few reclamation options. The land was first cleared for sugarcane (Saccharum spp.), then on a

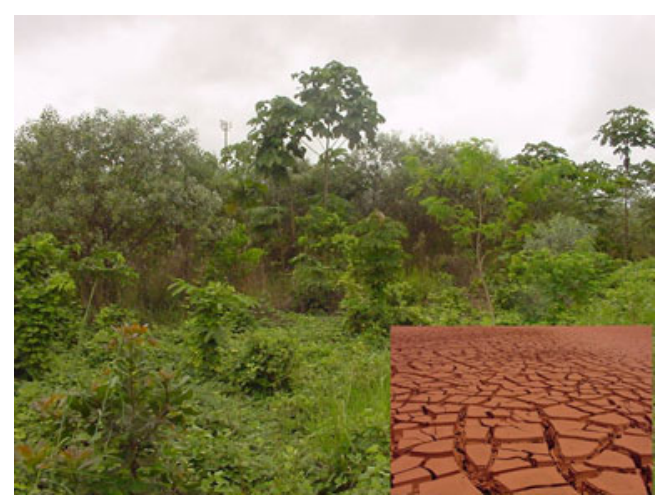

Fig. 7 Revegetation of land used for disposal of mine waste (bauxite) by legumes trees. Small picture inserted: land before planting. Main picture: land after 3 years of legume growth. Photo: R. M. Boddey, Embrapa much wider scale for coffee (Coffea robusta), and in the last century for charcoal for iron founding (Dean 1995; Boddey et al. 2003). Some of the land has become so degraded that it has been completely abandoned, while in other areas the land is utilized by small landholders for only extremely low productivity crop production or for extensive cattle grazing (Szott et al. 1999). In both cases, it is common practice to burn off the vegetation at least once a year either to facilitate planting or to exploit grass regrowth for forage. Burning exacerbates the loss of nutrients and soil organic matter; erosion becomes a problem and the degradative processes are accelerated. Few attempts have been made to revegetate seriously degraded areas, but over the last 20 years a team at Embrapa Agrobiologia has developed a technology based on the use of fast-growing legume trees from the genus Acacia (Acacia mangium, Acacia holosericea, Acacia angustissima, and Acacia auriculiformis), Albizia lebbeck, Mimosa caesalpiniifolia, Pseudosamanea guachapele, Enterolobium contortisiliiquum, Sclerolobium paniculatum, and Sthryphnodendrum purpureum (Chaer et al. 2011; De Faria et al. 2011).

In cleared land and severely degraded soils, or where new tree legume species are being grown for the first time, populations of rhizobia capable of nodulating tree legumes and forming an effective symbioses tend to be extremely low and tree legumes commonly fail to fix $\mathrm{N}_{2}$ or prosper if planted without appropriate rhizobial inoculation (Galiana et al. 1998; Thrall et al. 2005). Consequently, considerable effort has been placed on isolating and selecting effective rhizobia for a number of woody legume species suitable for use in temperate or tropical environments (Franco and de Faria 1997; Galiana et al. 1998; Thrall et al. 2005).

Recently, three Brazilian studies have highlighted the potential effects of tree legume species on the soil $\mathrm{C}$ stocks where they have been used in degraded areas. The first study was at a sloping site where, in 1989, a large amount of the top $40 \mathrm{~cm}$ of soil was removed to construct an irrigation dam reducing the SOC stock to 44.5 $\mathrm{Mg} \mathrm{Cha}{ }^{-1}$. Originally, the slope was covered by Guinea grass (Panicum maximum). The SOC stocks (0$60 \mathrm{~cm}$ ) were found to have been increased by $21 \mathrm{Mg} \mathrm{C}$ $\mathrm{ha}^{-1}$ (average rate of $1.4 \mathrm{Mg} \mathrm{Cha}^{-1}$ per year) over a period of 15 years by growing M. caesalpiniifolia and by $55 \mathrm{Mg} \mathrm{Cha}{ }^{-1}$ (average rate of $3.7 \mathrm{Mg} \mathrm{Cha}^{-1}$ per year) with A. auriculiformis and P. guachapele (Boddey et al. 2009; Chaer et al. 2011).

The second study, near Angra dos Reis on the coast of Rio de Janeiro, was a steep slope $\left(\sim 50^{\circ}\right)$ which had been deforested and the top soil removed (Macedo et al. 2008). A recovery operation began in 1991 by planting $A$. mangium, A. holosericea, and M. caesalpiniifolia. Part of the deforested hillside was left unplanted while 1,000 m 
further east along the hillside was an area of the original forest. All three sites (unplanted, tree legumes, and original forest) were sampled to a depth of $60 \mathrm{~cm}$. The $S O C$ under the undisturbed Atlantic forest was $108 \mathrm{Mg} \mathrm{Cha}^{-1}$ while the SOC under the unplanted hill and tree legume hill was 65 and $88 \mathrm{Mg} \mathrm{Cha}^{-1}$, respectively.

A further study was undertaken on an experimental area established in degraded secondary forest near the town of Valença (Rio de Janeiro state; Torres et al. 2007). Replicated plots $(25 \times 50 \mathrm{~m})$ of mixtures of different $\mathrm{N}_{2^{-}}$fixing and non- $\mathrm{N}_{2}$-fixing legume tree species and nonlegume trees were planted in different proportions: $0 \%$, $25 \%, 50 \%$, and $75 \% \mathrm{~N}_{2}$-fixing legumes. In 6 years, the $\mathrm{C}$ in tree biomass (including roots) and litter was estimated to represent $16 \mathrm{Mg} \mathrm{Cha}^{-1}$ where non- $\mathrm{N}_{2}$-fixing trees were planted, and $47 \mathrm{Mg} \mathrm{ha}^{-1}$ in the treatment with $75 \% \mathrm{~N}_{2}$ fixing legume trees. Soil $\mathrm{C}$ stocks $(0-60 \mathrm{~cm})$ under the plots with $50 \%$ legumes $\left(84 \mathrm{Mg} \mathrm{Cha}^{-1}\right)$ was significantly greater than where no legume was present $\left(71 \mathrm{MgCha}^{-1}\right)$ representing an annual rate of SOC change of $2.17 \mathrm{Mg} \mathrm{C}$ $\mathrm{ha}^{-1}$ per year (Torres et al. 2007).

The limited data on tree legume effects on SOC from elsewhere in the world suggest that the Brazilian case studies described above may not be unique. The average annual rates of SOC accumulation in the topsoil $(0-15 \mathrm{~cm})$ from leucaena (Leucaena leucocephala) compared to grass pastures or cropping soils in tropical Australia were reported to range from 0.08 to 0.26 and $0.76 \mathrm{Mg} \mathrm{Cha}^{-1}$ per year following 38, 20, and 14 years of leucaena, respectively (Radrizzani et al. 2011). The applications of leucaena and Senna siamea residues $(\mathrm{C} / \mathrm{N}=13: 1$ and 18:1, respectively) to an Imperata cylindrical grass fallow in West Africa were also found to be more effective at increasing SOC $(0-20 \mathrm{~cm})$ than applications of similar amounts of residue $\mathrm{C}$ as maize stover $(\mathrm{C} / \mathrm{N}=58: 1$; Gaiser et al. 2011).

Conclusions The case studies described here confirm the perceived benefits of using $\mathrm{N}_{2}$-fixing woody perennials to accumulate SOC in soil in addition to their capacity to provide a strong sink to sequester $\mathrm{CO}_{2}$ in their biomass. Interestingly, the increases in SOC stocks (1.4-2.2 Mg C $\mathrm{ha}^{-1}$ per year, $0-60 \mathrm{~cm}$ ) observed in the Brazilian studies were achieved solely through litter fall from the canopy. This may have represented between 5 and $11 \mathrm{Mg}$ DM ha ${ }^{-1}$ per year (Chaer et al. 2011). There is potential to more intensively manage some legume shrub and tree species by regularly harvesting foliage which could allow for up to 20 to $30 \mathrm{Mg} \mathrm{DM} \mathrm{ha}^{-1}$ (Peoples et al. 1996) to be applied as greenmanure to accelerate $\mathrm{C}$ accumulation in soil. However, the data of Radrizzani et al. (2011) remind us that the rates of change in SOC beneath woody perennial legume systems will inevitably decline over time.

\section{A role for legumes to replace fossil resources?}

Biomass can potentially be used to replace fossil hydrocarbons for heat, power, solid and liquid fuels, materials, or chemicals (Bessou et al. 2010). The global energy demand is expected to increase by about $45 \%$ by 2030 with the main increase occurring in non-OECD countries (IEA 2009). While fossil fuels are expected to still account for $80 \%$ of the world energy requirement in 2030 with oil remaining as the dominant energy source, biomass is projected to be the most important primary source of renewable energy. Biomass is predicted to provide about $9 \%$ of the total energy requirement and around $5 \%$ of the world road transport fuels (IEA 2009). This represents a $40 \%$ increase compared to 2006 in terms of million tons of oil equivalents (Mtoe).

In a biobased economy, fossil resources are replaced by biomass for the production of industrial chemicals, transportation fuels, electricity, heat, and other products. The world demand for biomass in renewable energy production is predicted to increase from 1,186 Mtoe to 1,660 Mtoe in 2030 (IEA 2009) with the EU and USA targeting a 25-30\% replacement (Mabee et al. 2006). Second-generation biofuel technologies based on lignocellulosic feedstock are expected only to be deployed to a minor degree in 2030 due to the major improvements that will be required in conversion technologies involving the enzymatic hydrolysis of sugars (Mabee et al. 2006; IEA 2009). A major part of the biomass is projected to come from agricultural crops and residues as well as forest residues, with a growing share coming from purpose-grown energy crops (IEA 2009; Fig. 8).

Concerns about dwindling petroleum reserves and needs to supply sources of energy with lower GHG emissions are not the only drivers for these changes. The re-emergence in interest in biofuels and biomass feedstocks have also been encouraged by insecurities about on-going petroleum

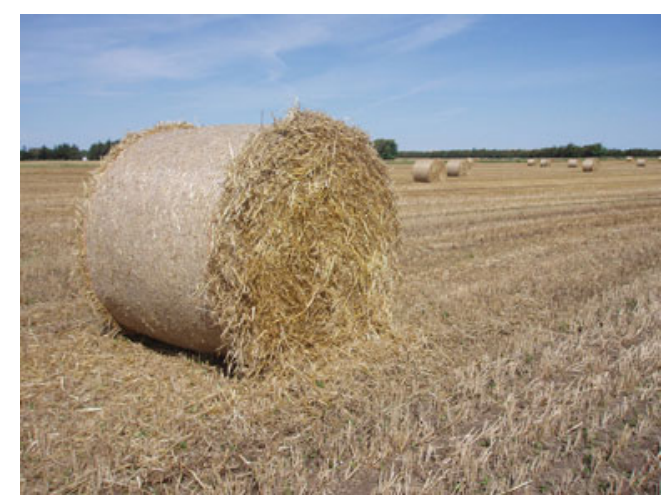

Fig. 8 Straw and stover from annual crops are valuable resources for soil carbon sequestration, but sustainable use for biorefineries may be possible from fertile land with high soil $\mathrm{C}$ contents. Photo: E. S. Jensen, SLU 
supplies in light of the recent instabilities in the oil-rich Arab world, and Japan's nuclear crisis following the 2011 tsunami which has caused many countries to re-assess their reliance upon nuclear power as a source of low-C electricity (Fairley 2011).

There are also a number of concerns about the environmental credentials and socio-economic effects of present bioethanol and biodiesel production from crops (Pimentel 2003). Foremost of these concerns are (1) the implications for food availability and security where energy crops displace food production, (2) GHG emissions if the increased demand for cropping land for biomass crops either directly or indirectly results in the clearing of forested areas, and (3) supplying fertilizer inputs to support the growth of high yielding and high biomass crops. This final issue is one of the key factors contributing to the reduction of the $\mathrm{C}$ neutrality of biomass systems because the fossil fuels involved in fertilizer production and transport can effectively negate the whole of life-cycle energy benefits. The attraction of legumes is their ability to satisfy their own $\mathrm{N}$ requirements from symbiotic $\mathrm{N}_{2}$ fixation (Herridge et al. 2008). Although it should be noted that legume species differ enormously in their reliance upon $\mathrm{N}_{2}$ fixation for growth in the field, with dry bean (also known as common bean or French bean; Phaseolus vulgaris) often fixing the least, and soybean and faba bean fixing the most (Peoples et al. 2009a).

Clearly, it will be necessary to justify the sustainability of biomass production systems if they are to be seen as a viable alternative to fossil resources and before real progress can be made towards meeting the predicted demand. Biomass systems for energy production will also be required to be multifunctional contributing several components or aspects to society (IAASTD 2009). The following sections analyze the potential role of legumes in contributing to future biobased economies.

\subsection{Legume biomass yield potential and constituents}

Biomass production for bioenergy feedstock will ideally require a high net biomass per unit area with a low amount of fossil energy input resulting in low fossil energy requirement per kilogram of DM produced. Although legume grain yields have increased in most regions during the last 30 years, yield enhancements are small compared to those observed in wheat and maize. As a result, legume grain yields tend to be lower than cereals in many countries of the world (e.g., Tables 6 and 7; FAOStat 2010). Areas sown to crop legumes have also declined globally for almost all species except soybean in the last few decades (Jensen et al. 2010; FAOStat 2010). Globally, cereals were grown on almost 700 million ha of land in 2009 compared to a total of 193 million ha sown to pulses and legume oilseed crops such as soybean and groundnut (Arachia hypogea).

Second-generation biofuels, power and heat generated by combustion and production of industrial raw materials could be based on legume biomass and residues. However, the amount of legume stubble remaining after grain harvest is often lower than residual cereal straw biomass, which clearly would impact on the relative economics of using legume sources rather than cereals as feedstock.

Part of the reason that legume dry matter yields tend to be lower than of cereals may be explained by the fact the legumes are high in proteins and/or oil and that the energetic cost of producing proteins and oil are higher than producing cell walls, starch, and soluble sugars (MunierJolain and Salon 2005). The energetic cost of producing $1 \mathrm{~g}$ of pea grain was determined to be $1.8 \mathrm{~g}$ glucose equivalents compared to $1.6 \mathrm{~g}$ glucose equivalents for $1 \mathrm{~g}$ wheat grain. In this calculation, it was assumed that the cost of producing $1 \mathrm{~g}$ of starch is 1.21 gglucose $\mathrm{gstarch}^{-1}$, whereas

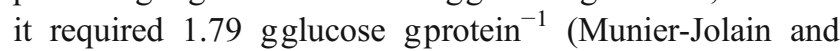
Salon 2005). Based on the different constituents of legumes and non-legumes, the relation between average yields and the constituents of a spectrum of arable crop are shown in Fig. 9. Species with similar theoretical $\mathrm{C}$ costs of seed production can have different yields (e.g., faba bean and chickpea; Fig. 9). The authors suggested that this could be due to different investments in breeding and development of cultivation techniques of the different species (MunierJolain and Salon 2005). However, the greater C cost associated with legume grain synthesis compared with

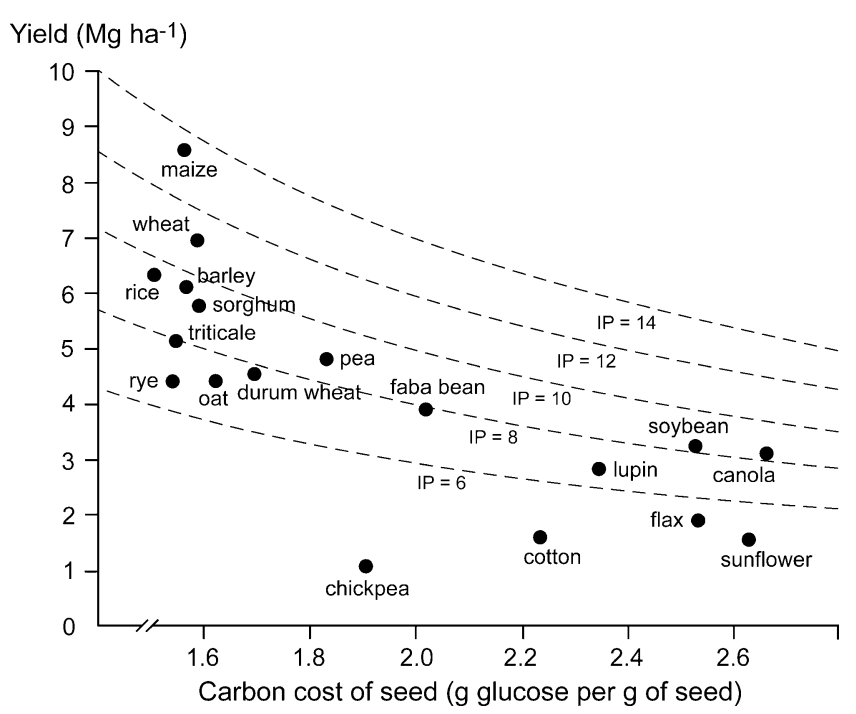

Fig. 9 Relationship between the $\mathrm{C}$ cost of seed production for selected legume and non-legume crops. In order to compare crop production performance, various isoproduction (IP) curves expressing the product of the energy cost of $1 \mathrm{~g}$ of seed by the yield have been indicated (after Munier-Jolain and Salon 2005) 
cereals may be compensated by higher rates of photosynthesis and delayed leaf senescence (Kaschuk et al. 2010).

Less focus has been placed on the use of legumes for biomass feedstock for energy and industrial raw materials. A comprehensive European inventory of crops for bioenergy did not include any legumes (Venendaal et al. 1997). Legumes have high contents of constituents other than carbohydrates, which may be relevant in biorefinery concepts (see Section 3.2), in which the different components could be used for a variety of biobased products. For example, legume biomass might be used to generate biogas $\left(\mathrm{CH}_{4}\right)$ and N-rich biofertilizer via anaerobic digestion, and the grain utilized for biodiesel and/or protein feed.

Table 10 and Fig. 10 give an overview of the main constituents of some common legumes as compared to wheat and maize. Since the grain of crop legumes and soybean have high concentrations of protein and oil, the levels of starch tend to be lower than cereals (Table 10). Only pea has a starch content which approaches the levels observed in wheat and maize. Due to their high starch content, pea is often used as an energy component in compound feed. Other carbohydrates in Table 10 include simple sugars, cellulose, hemicelluloses, and lignin. Mature wheat straw and maize stover contain around $40 \%$ cellulose (C6) and 25\% hemicelluloses (C5), 10-12\% lignin, and 9\% protein (Duke 1983). By comparison, the vegetative residues of soybean contain $44-83 \%$ cellulose and 5-14\% lignin, although it should be acknowledged that the determinations of hemicellulose, cellulose, and lignin depend strongly on the analytical methodology used (Reddy and Yang 2009). The protein concentration in the crop legume residues is greater than in cereals and can reach values as high as 10\% (Jensen 1989). Similarly, forage legume biomass has high concentrations of protein, which could warrant the use of technology to extract the protein as a potentially valuable by-product when the biomass is used for biofuels. In addition, legumes contain many interesting compounds, such as alkaloids and isoflavonoids, which may be useful for human and animal health, as well as having applications for industrial uses (Duranti et al. 2008; Dixon and Sumner 2003; Pregelj et al. 2011).

Legume breeding efforts to date have only considered enhancing the concentration of grain protein or oil (in the case of soybean) for livestock or human consumption. The focus of future breeding programs could shift to greater dry matter yields with reduced protein concentrations for biofuels. Legumes can also be grown as part of mixed crop communities with greater diversity to exploit better available resources and deliver several ecosystems services (Jensen and Hauggaard-Nielsen 2003; Figs. 3 and 11).

Conclusions Legumes are lower yielding and have higher protein concentrations than cereals, which have resulted in less interest in their use as sole crops for biofuels. Legumes can be valuable components in mixtures with other species that might be suitable for biorefinery concepts. This is especially the case if the biorefinery is designed to exploit both carbohydrates and protein.

\subsection{Legumes as biorefinery feedstocks for biofuels, materials, and chemicals}

A biorefinery is defined as the sustainable processing of biomass into a spectrum of marketable products and energy (Cherubini et al. 2009) by the use of physical (fractionation, pressing), chemical (acid hydrolysis, synthesis, esterification), thermochemical (pyrolysis, gasification, combustion), and biochemical (enzymatic and fermentation) methods (De
Table 10 Constituents of selected cereal and legume species expressed as percentage of dry matter

\begin{tabular}{lllll}
\hline Crop and component & Starch (\%) & $\begin{array}{l}\text { Other } \\
\text { carbohydrates } \\
\text { (C5, C6, a.o.) (\%) }\end{array}$ & Protein (\%) & Fat (\%) \\
& Lignin (\%) \\
\hline
\end{tabular}

\begin{tabular}{|c|c|c|c|c|c|}
\hline \multicolumn{6}{|l|}{ Grain } \\
\hline Maize & 71 & 14 & 9 & 5 & 2 \\
\hline Wheat & 66 & 17 & 13 & 3 & 2 \\
\hline Soybean & 15 & 14 & 41 & 21 & 6 \\
\hline Pea & 55 & 18 & 25 & 2 & 6 \\
\hline Lupin & 22 & 23 & 45 & 5 & 16 \\
\hline Faba bean & 42 & 21 & 31 & 1 & 9 \\
\hline \multicolumn{6}{|l|}{ Above-ground biomass } \\
\hline Wheat stubble & 0 & 92 & 3 & 2 & 45 \\
\hline Pea residues & 0 & 81 & 7 & 2 & 41 \\
\hline Grass-clover ( $30-50 \%$ clover) & 2 & 62 & 22 & 4 & 20 \\
\hline Alfalfa (after flowering) & 2 & 72 & 20 & 3 & 31 \\
\hline
\end{tabular}

Collated from data presented by the Danish Feed Analysis (2005), Duke (1981, 1983), and Samac et al. (2006) 
Fig. 10 Legume constituents and potential products from legume biorefineries

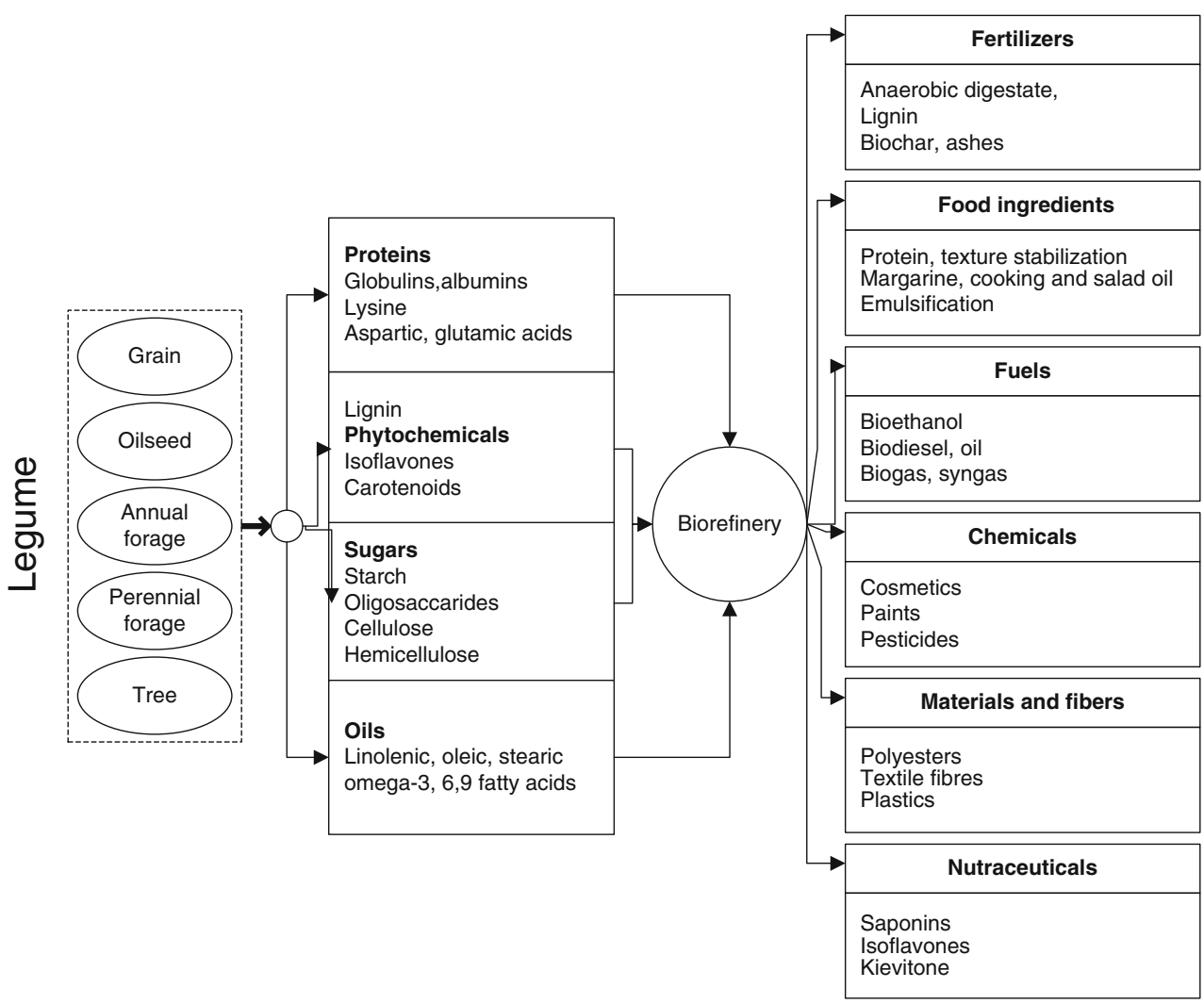

Jong et al. 2010). The aim is to optimize the sustainable use of specific biomass resources available in a given region to ensure both resource use efficiency and economic/environmental sustainability.

A biorefinery may be simple with only a single or few products such as bioethanol and heat or refined sugar and feed. Alternatively, the biorefinery could produce a spectrum of different biobased products in a way analogous to a petrochemical refinery. Different concepts for biorefineries have been described: well-known simple biorefineries produce sugar, potato starch, wheat starch, soybean oil, and protein. Dry milling refineries use cereals grains for

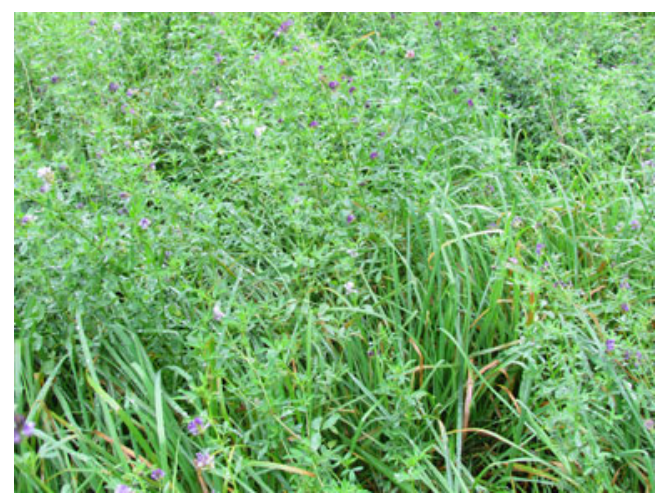

Fig. 11 Perennial mixtures of forage legumes and grasses, e.g., alfalfa and cocksfoot (Dactylis glomarata), can produce abundant amounts of biomass suited for anaerobic fermentation to biogas and biofertilizer. Photo: E. S. Jensen, SLU bioethanol production and dried distillers grains with solubles (DDGS) for feed. Oleochemical biorefinery produce oils, lubricants, platform chemicals, and biodiesel from canola and soybean (De Jong et al. 2010). Lignocellulosic biorefineries have been used for many years with forestry biomass for the production of paper pulp, chemicals, and energy. During the past decade, there has been a rapid development of sugar platform biorefineries using different types of lignocellulosic biomass (straw, short rotation coppice, perennial energy crops) as feedstock for production of bioethanol, feed, and power (De Jong et al. 2010). A green biorefinery is another concept developed for green biomasses such as grass-clover, alfalfa, and sugar beet (Beta vulgaris) leaves to produce amino acids, feed, fibers, and residues for biogas production (Novalin and Zweckmair 2008; De Jong et al. 2010). Even though there is an increasing interest in biorefineries, examples of successful advanced biorefinery concepts which have developed further than the pilot scale are limited (De Jong et al. 2010).

As indicated above, legumes are already used as biorefinery for feedstock. However, for a biorefinery which is either completely or partly based on legume feedstock, to be considered as economically viable, it will be necessary to consider how value can be derived from the high concentration of protein and/or oil, perhaps along with other natural compounds present. An outline of a simplified theoretical biorefinery concept for a legume feedstock is provided in Fig. 12. In the following section, we present 
evidence related to the production of biofuels, electricity/ heat, materials, and chemicals based on legume feedstock, without emphasis on combining the different technologies in specific legume biorefineries.

Conclusions A biorefinery is a key component in future biobased economies, which will contribute to the replacement of fossil-resource-based economies. Concepts are currently developing quickly worldwide, but soybean is the only legume used to a certain extend for protein feed and biodiesel. There is scope for utilizing other legumes species if their protein and other potentially valuable constituents can be extracted and converted into marketable products.

\subsubsection{Biofuels}

Renewable sources of energy derived from technologies such as solar panels or wind turbines will be able to supply electricity, but in reality the vast majority of the world's transport systems are based on motor vehicles and aircraft which require liquid fuels and will do so for the foreseeable future. The recognition that sustainable sources of biofuels will need to be a key part of our global energy future is reflected in the trends in the annual output of bioethanol and biodiesel which has expanded more than 6-fold between 2000 and 2010 (IEA 2009; Fairley 2011).

\subsubsection{Bioethanol}

Bioethanol production is based on the microbial fermentation of sugars into ethanol. Bioethanol produced from simple sugars (e.g., from sugar cane and sugar beet) and starch are termed first-generation bioethanol, whereas bioethanol derived from lignocellulose in straw, stover, perennial biomass crops [e.g., Miscanthus; willow (Salix spp.); reed canary grass (Phalaris arundinacea); mixed grass-clover swards; alfalfa] are termed second-generation bioethanol (Mabee et al. 2006).

Field pea grain has been studied as a potential feedstock either alone or as a supplement with maize grain for firstgeneration bioethanol production because of its high starch content (Table 10; Nichols et al. 2005; Pryor et al. 2008). Fermentation of whole peas and a dry-separated (starch and protein fraction separated by air classification of milled pea grain) pea starch fraction gave satisfactory ethanol yields (Nichols et al. 2005). The enriched starch fraction in combination with maize starch gave similar or greater ethanol yield than maize starch alone (Pryor et al. 2008). Improved or similar ethanol production occurred with pea starch, despite its less favorable amylase/amylopectin ratio since it has been shown that it is more difficult to convert amylose than amylopectin starch to fermentable sugars, and pea contains $30 \%$ to $50 \%$ amylose compared to $20 \%$ to $30 \%$ in maize starch (Pryor et al. 2008).

The consequences of reallocating land from food production to bioenergy purposes, and the overall sustainability of the first-generation technology for bioethanol production, remains controversial (Pimentel 2003; Pimentel and Patzek 2005; Fairley 2011). Hammerschlag (2006) found that the ratio of energy in a liter of ethanol to the non-renewable energy required to produce it with firstgeneration technologies varied across six different pub-
Fig. 12 Principles of a legume biorefinery

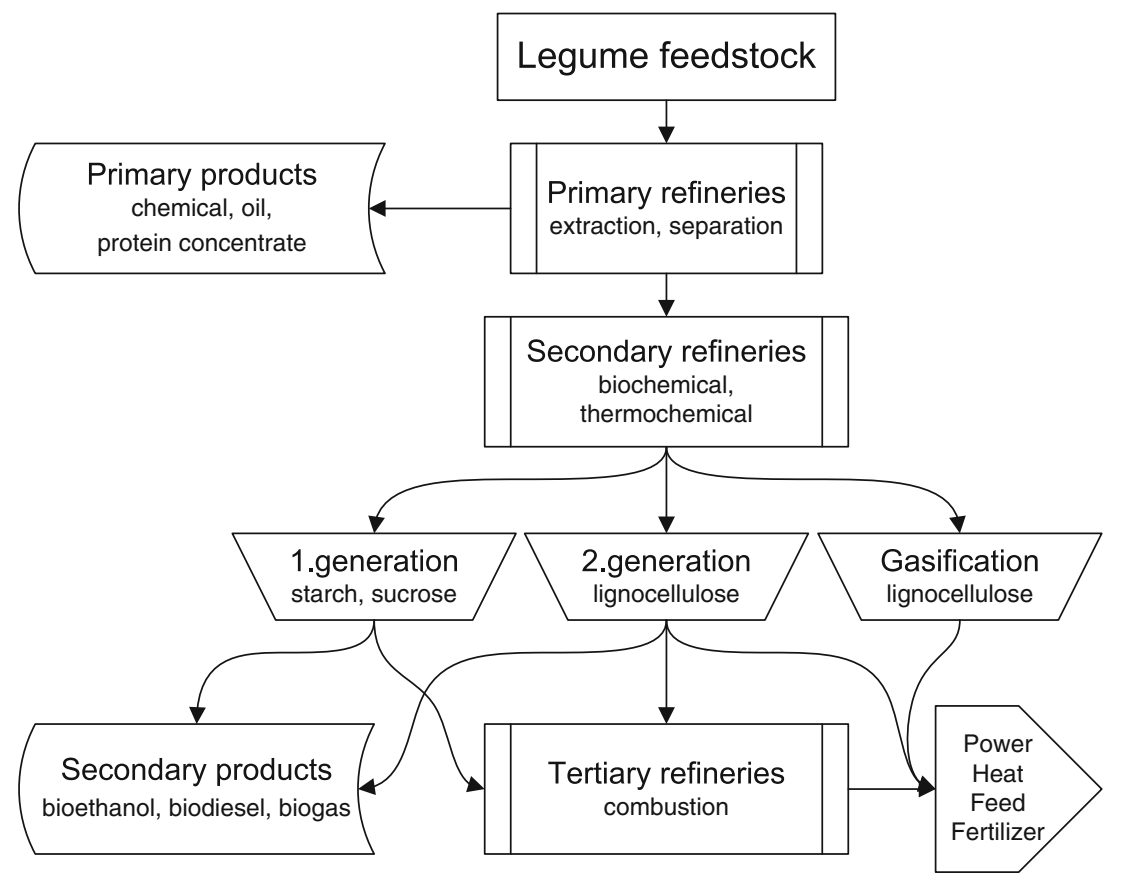


lished studies. In one study, more non-renewable energy was required to produce ethanol from maize grain than was present in the final bioethanol product with an energy balance of 0.84 . By contrast, another study with maize estimated an energy balance of 1.65 times more renewable energy generated than non-renewable energy used, when the energy content of the by-products were included in the calculations of the energy return on investment (Hammerschlag 2006). The use of nonrenewable energy for fertilizers, especially $\mathrm{N}$, represented from $10 \%$ to $20 \%$ of the total energy inputs. The lower starch yield per unit area of land by crop legumes compared to cereals will probably prevent their increased use for first-generation bioethanol. However, intercropping grain legumes with high starch-yielding non-legumes may be an alternative option (Hauggaard-Nielsen et al. 2009).

The second-generation conversion technology for lignocellulosic materials into bioethanol appears more promising in terms of the potential of using feedstock and land which is not in direct competition with food production. Lignocellulose conversion technology is more complex than first-generation bioethanol production, primarily due to the presence of both C6 and C5 sugars, which are imbedded in lignin and consequently not easily accessible by the cellulases and hemicellulases that are required to convert cellulose and hemicellulose into fermentable sugars. Consequently, a biomass pre-treatment process is required to open the lignocellulosic structure (Mabee et al. 2006). In recent years interest has increased in second-generation bioethanol from feedstock that is not in direct competition with food production since this concept could be more sustainable in terms of GHG emissions, fossil energy use, energy balance, and resource use. Hammerschlag (2006) reported energy of investment (bioethanol energy per unit non-renewable invested energy) to be up to 4.4 and $6.6: 1$ for lignocellulose-derived bioethanol from maize stover and poplar.

Vegetative biomass from grain and oilseed legumes is a possible source of feedstock for second-generation bioethanol, but DM yields tend to be lower per unit area and the stubble contains more protein and a lower content of cellulose than cereal alternatives (Table 10). Consequently, the ethanol yield will be lower.

Perennials are a promising option because of their efficient use of resources and lower requirements for farming operations than annual crops (Bessou et al. 2010). Alfalfa is an interesting candidate as a perennial legume feedstock for biofuel and bioproducts since it can yield between 4 and $18 \mathrm{Mg} \mathrm{DM} \mathrm{ha}{ }^{-1}$ per year (average of $8 \mathrm{Mg} \mathrm{DM} \mathrm{ha}{ }^{-1}$ from three to four annual harvests) for up to 4 years of growth (Samac et al. 2006). Alfalfa requires fertile, deep, and well-drained soils and adequate supply of water, although its deep rooting system makes alfalfa more resistant to dry periods than many other crops. Alfalfa stems containing $10-12 \%$ protein can be used for bioethanol production while the leaves with $26-30 \%$ protein can be used as a high-protein feed (Dale 1983) or further processed to a high-value protein product. New germplasm and cultivation methods (plant density and cutting regime) have been developed for alfalfa to provided modified stem/ leaf ratios that are more suitable for bioethanol production (Lamb et al. 2003). Research has been done to determine how the polysaccharide composition of alfalfa stems can be modified by cultivation and harvest frequency in order to produce the most optimal biomass for conversion to bioethanol (Samac et al. 2006). Besides being a potential feedstock for bioethanol, stems are also evaluated as feedstock for the production of lactic acid, which can be used for bioplastic, as a replacement for petroleum-based plastics (Koegel et al. 1999).

Other perennial legumes, such as clovers, could be used as feedstock for second-generation bioethanol either grown as sole crops or in mixtures with grasses. Thomsen and Hauggaard-Nielsen (2008) found that the theoretical bioethanol potential (based on carbohydrate composition) of wheat straw and grass-clover crops were similar at 270 and $240 \mathrm{~L}$ per megagram of DM. With biomass yields of $5 \mathrm{Mg}$ of wheat straw DM and $10 \mathrm{Mg}$ grass-clover DM ha ${ }^{-1}$ in Denmark, the production would be 1.35 and $2.4 \mathrm{Mg}$ bioethanol $\mathrm{ha}^{-1}$, respectively. If a grass-clover cover crop was undersown to wheat, a further $0.96 \mathrm{Mg}$ bioethanol ha ${ }^{-1}$ could be produced from the autumn biomass growth of the cover crop (Thomsen and Hauggaard-Nielsen 2008).

Intensive agroforestry systems also have a potential role in producing large amounts of biomass. For example, densely planted tree legumes such as Calliandra calothyrsus and Gliricidia sepium in the Australian tropics yielded up to 20 to $30 \mathrm{Mg} \mathrm{DM} \mathrm{ha}{ }^{-1}$ as foliage and stem re-growth over an annual cutting cycle when periodically cut as hedgerows (Peoples et al. 1996). Some woody perennial legume species are also suitable for use on marginal or degraded lands (see Section 2.3.4).

The deep-rooted nature of both herbaceous and woody perennial legumes also offer an effective, low-cost method for (1) remediating excess soil $\mathrm{N}$ and lowering the risk of groundwater contamination by nitrate (Randall et al. 1997; Entz et al. 2001), and (2) reducing the risk of rising water tables and the development of dryland salinity (Angus et al. 2001; Lefroy et al. 2001).

Conclusions Annual crop legumes do not seem particularly attractive for bioethanol production due to their low starch yield per unit area. Perennial legumes such as alfalfa, on the other hand, offer an interesting resource for future secondgeneration bioethanol production either as sole crop or in mixed cropping with high-yielding non-legume species. 


\subsubsection{Biodiesel}

Biodiesel is produced by the transesterification of the glyceride molecules in plant oils by methanol to produce glycerine and methyl esters (Mabee et al. 2006), which can readily be used in diesel engines. The production of glycerine and the need for methanol detract somewhat from the attractiveness of biodiesel. New chemical procedures are now in place allowing the production of liquid biofuels (such as aviation fuel) out of plant oils without esterification. The nature of the fatty acid composition controls critical physical properties, such as the cloud point (the temperature at which the diesel will turn cloudy and thus clog injection systems). A low concentration of palmitic (C16:0) and stearic (C18:0) acids and a high concentration of oleic (C18:1) acid is optimal (Kazakoff et al. 2011).

Brazil produced 58 million Mg of soybean in 2007, and extracted 5.7 million Mg of oil, part of which was used for biodiesel production (Elbersen et al. 2010). One megagram of soybean yields about $170 \mathrm{~L}$ of biodiesel; consequently, the potential of Brazilian biodiesel production from soybean is about 10 billion liters if all the oil was used for this purpose. In comparison, the global biodiesel production level in 2006 was 2.7 million liters, with Germany being the largest producer of about 1.2 million liters derived from canola (Mabee et al. 2006).

Soybean in Brazil and Argentina is estimated to obtain approximately $80 \%$ of its $\mathrm{N}$ from BNF (Herridge et al. 2008). In the USA (the world's largest producer), soybean reliance upon BNF for growth is somewhat less $(\sim 60 \%)$ due to the more fertile soils in the midwest and the residual $\mathrm{N}$ fertilizer from maize crops in the rotation. China may have even lower inputs of fixed $\mathrm{N}$ by soybean as yields are lower and $\mathrm{N}$ fertilizer use is higher (Herridge et al. 2008).

Embrapa Agrobiologia has developed an energy balance for soybean production under typical mechanized farming practice in the Cerrado region of Brazil based on the national average grain yield of $2.82 \mathrm{Mg} \mathrm{ha}^{-1}$ with a total oil yield of 18\% (Table 11; Boddey et al. 2009; IBGE 2011; Soares et al. 2007). Since soybean must be re-planted each year, agricultural and transport energy costs proportionately make an important contribution to total fossil energy use (Table 11). Fossil energy inputs for fertilizer are low as little $\mathrm{N}$ fertilizer is applied. While fuel inputs under no-till systems were much lower than under conventional tillage, much of the economy in fossil fuel was compensated for by the energy required for herbicide manufacture and application (assumed to be glyphosate in this case). When the fossil energy costs for transesterification is included, the energy balance of biodiesel energy/non-renewable energy is almost unity (1.06:1), suggesting no overall GHG mitigation effect (Table 11). At the same time, $>2.3 \mathrm{Mg} \mathrm{ha}^{-1}$ of high-protein soybean meal was co-produced with an energy content of $38.7 \mathrm{GJ} \mathrm{ha}^{-1}$. If the energy in this high-protein by-product is added to the biodiesel produced, the energy balance becomes much more favorable at 3.2:1 (Table 11), but still compares poorly to estimates of 9.07:1 determined for sugarcane using the same methodologies (Boddey et al. 2008). Unfortunately, and in contrast to the Pimentel and Patzek (2005) study, the energy required to build and maintain the factory infrastructure for processing was not included in the Brazilian calculations for soybean, nor were they considered in similar energy balance study undertaken for soybean biodiesel in the USA which cited a similar energy balance (3.2:1; Sheehan et al. 1998).

The fast-growing legume tree Pongamia pinnata (also called Millettia pinnata) may be a significant future source of oil for production of biodiesel since the seeds contain around $40 \%$ oil, with the predominant fatty acids being oleic, palmitic, stearic, and linoleic (Scott et al. 2008; Kazakoff et al. 2011). Pongamia oil is non-edible, but is not toxic to humans. Pongamia oil contains about $50-55 \%$ oleic acid, with about $7-10 \%$ palmitic and stearic acid.

While Pongamia is tropical in origin, it will grow and yield well in the coastal Brisbane area of Queensland, Australia (Fig. 13). In winter, it goes dormant allowing it to survive temperatures as low as $-5^{\circ} \mathrm{C}$ (Wilkinson et al. 2012). An initial life cycle and growth analysis of a Pongamia plantation at Gatton, on the tablelands of southern Queensland, found that up to 500 flowers developed per tree within 2 years of planting. At a tree density of about 350450 trees $\mathrm{ha}^{-1}, 10$-year-old trees are capable of producing an oil yield of around $5 \mathrm{Mg} \mathrm{ha}^{-1}$ per year (Scott et al. 2008; Fig. 14). Seeds are mechanically harvested and can be stored before solvent or cold press oil extraction.

The Pongamia trees are extremely drought tolerant, owing to their deep root system, waxy leaf, and favorable stress physiology. They are also salt tolerant, so they could be grown on margin lands and in soils unsuited for food production (Wilkinson et al. 2012). In addition to high oil content seeds, the Pongamia tree may supply biomass for other biobased applications. The seed pod (casing) is of equal mass to the single seed contained in it and has application in co-firing in electricity plants. The seed cake, after oil extraction, can yield protein concentrate for low quality animal feed supplement (especially ruminants), second generation bioethanol, biogas, or thermochemical conversion and production of biochar (see Section 3.2.4).

Conclusions If soybean is planted solely for the purpose of biodiesel manufacture, there is unlikely to be significant GHG mitigation benefits. If the objective is to produce high-protein feed, and the oil is a by-product, then energy balance may be as high as 3.5:1 and could represent an important GHG mitigation benefit. The legume tree 
Table 11 Fossil energy inputs, total energy yield, and energy balance for soybean diesel produced on 1 ha of land under standard Brazilian zero-till management systems
Grain yield was assumed to be the 2007 national average grain yield $\left(2,824 \mathrm{~kg} \mathrm{ha}^{-1}\right)$ with a total oil content of $18 \%$ resulting in $480 \mathrm{~L}$ of biodiesel per hectare

${ }^{\text {a }}$ Ratio of energy yield of soybean biodiesel to fossil energy used in crop production and transesterification

${ }^{\mathrm{b}}$ Ratio of total bioenergy yield of both biodiesel and soy meal by-product to fossil energy used in crop production and transesterification

\begin{tabular}{|c|c|c|c|}
\hline & Units per hectare & Amount & Energy (GJ) \\
\hline \multicolumn{4}{|l|}{ Operation } \\
\hline \multicolumn{4}{|l|}{ 1. Field preparation } \\
\hline Herbicides & $\mathrm{L}$ & 3.8 & 1.80 \\
\hline Mineral oil adjuvant & $\mathrm{L}$ & 0.5 & 0.02 \\
\hline Seeds for pasture & $\mathrm{kg}$ & 20 & 0.03 \\
\hline Lime & $\mathrm{kg}$ & 1000 & 1.17 \\
\hline \multicolumn{4}{|l|}{ 2. Crop establishment } \\
\hline Soybean seeds & $\mathrm{kg}$ & 50 & 1.65 \\
\hline Fungicides & $\mathrm{L}$ & 0.3 & 0.12 \\
\hline Inoculant & Dose & 2.0 & 0.01 \\
\hline Fertilizer $00-20-20$ & $\mathrm{~kg}$ & 500 & 0.62 \\
\hline \multicolumn{4}{|l|}{ 3. Crop management } \\
\hline Ant baits & $\mathrm{kg}$ & 1.0 & 0.36 \\
\hline Herbicides & $\mathrm{kg}$ & 0.65 & 0.29 \\
\hline Insecticides & $\mathrm{L}$ & 1.65 & 0.60 \\
\hline Fungicides & $\mathrm{L}$ & 1.5 & 0.45 \\
\hline \multicolumn{4}{|l|}{ 4. Machinery } \\
\hline Field operations and transport & $\mathrm{h}$ & 2.8 & 2.60 \\
\hline \multicolumn{4}{|l|}{ 5. Farm labor } \\
\hline Total & $\mathrm{h}$ & 8 & 1.34 \\
\hline \multicolumn{4}{|l|}{ 6. Fuel } \\
\hline Diesel oil & $\mathrm{L}$ & 58 & 2.76 \\
\hline Total & & & 13.82 \\
\hline \multicolumn{4}{|l|}{ Factor } \\
\hline \multicolumn{4}{|l|}{ Soybean bioenergy produced } \\
\hline Soybean oil & $\mathrm{kg}$ & 509 & 19.2 \\
\hline Soybean meal & $\mathrm{kg}$ & 2,316 & 38.7 \\
\hline Total bioenergy yield & & & 57.9 \\
\hline \multicolumn{4}{|l|}{ Fossil energy use } \\
\hline Agricultural energy costs & & & $(13.8)$ \\
\hline Transesterification (biodiesel production) & & & $(4.3)$ \\
\hline Total fossil energy use & & & $(18.1)$ \\
\hline Final energy balance for soybean biodiesel ${ }^{a}$ & & & $1.06: 1.0$ \\
\hline Total energy balance including soy meal ${ }^{\mathrm{b}}$ & & & $3.20: 1.0$ \\
\hline
\end{tabular}

Pongamia pinnata offers an interesting possibility for future biodiesel production with potential applications for legume-based biorefineries.

\subsubsection{Biogas and digestate for fertilizer from anaerobic digestion}

Anaerobic digestion is a key technology for the sustainable use of organic biomasses from industrial and urban organic wastes, animal manures, crop residues, and whole energy crops (Amon et al. 2007). Anaerobic digestion is particularly well suited for heterogeneous feedstock. It sanitizes the feedstock and can be applied at scales from the farm to big industrial plants. The biogas (mixture of $\mathrm{CH}_{4}$ and $\mathrm{CO}_{2}$ ) produced can be converted to electricity, heat, or upgraded to liquid biofuel for vehicles (Amon et al. 2007; Lehtomäki et al. 2008). Within the European Union, biogas production increased 6-fold from 1995 to 2005 (Eurostat 2007). Simultaneously, the digest residues consisting of nutrients and recalcitrant $\mathrm{C}$ enables almost complete nutrient recycling in the system, including $\mathrm{N}$. The digestate can be used as a fertilizer and enhance the synchrony of plant-available $\mathrm{N}$ and crop $\mathrm{N}$ demand since a major part of the organic $\mathrm{N}$ is mineralized to ammonium (Möller et al. 2008).

Legume biomass has as slightly lower $\mathrm{CH}_{4}$ production potential, as determined in batch fermentation assays, than maize and grass biomasses (Table 12). The $\mathrm{CH}_{4}$ production 

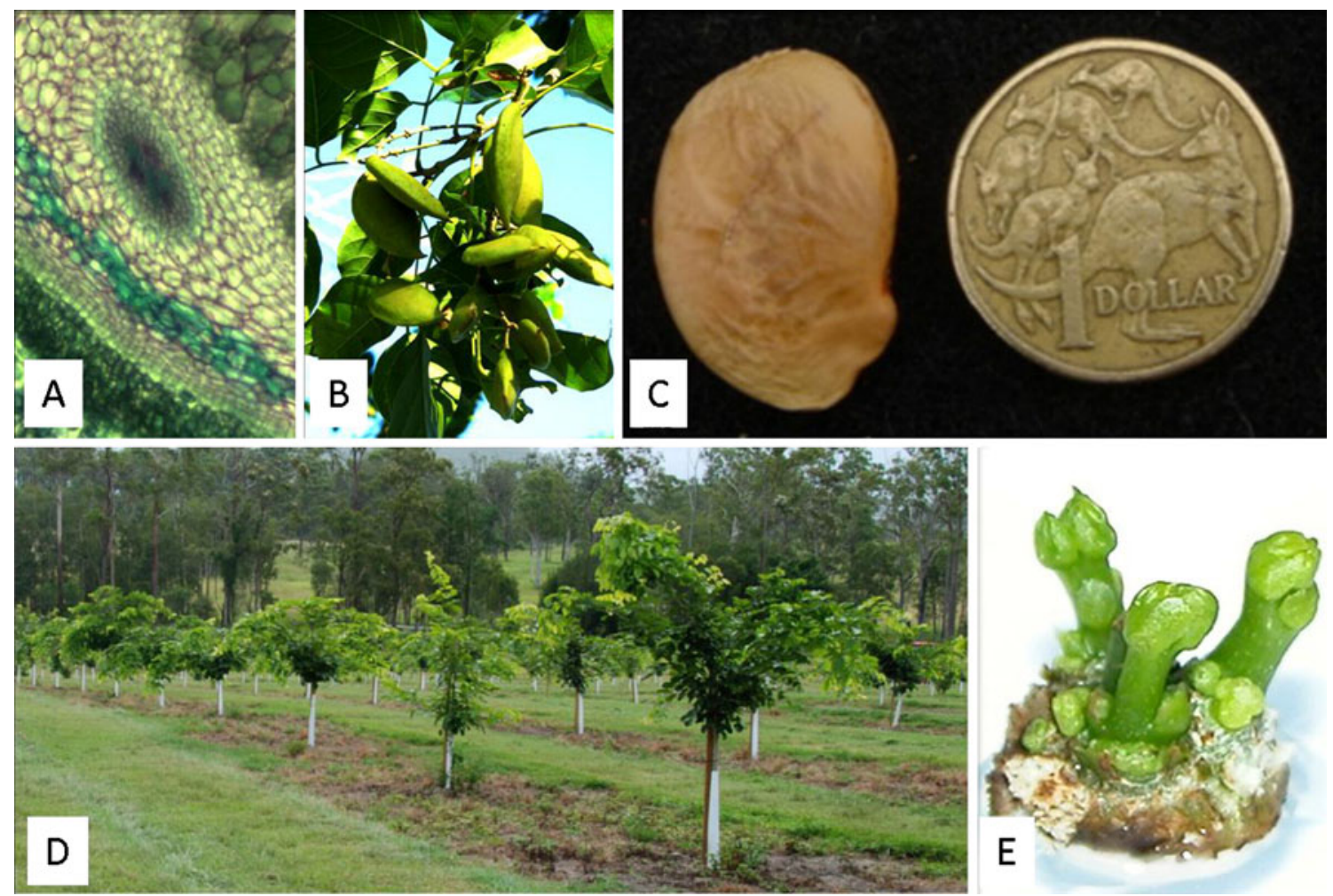

Fig. 13 Pongamia pinnata. A Pongamia nodule section showing infected, cortical, and vascular tissue. B Bunch of near-maturity Pongamia (Millettia) pinnata seed pods; up to 25 tons of total seed plus pod wall biomass coming from about 20,000 seeds per tree can be obtained per hectare on an annual basis with elite germplasm. Normally 400-500 trees are planted per hectare. C Seed of Pongamia (1.8 g average dry weight; $40-45 \%$ solvent extractable oil). D Rainfed Pongamia plantation (28 months old in southeastern Queensland, Australia). E Pongamia vegetative regeneration in cell culture. Photos: P. M. Gresshoff, CILR

depends on the biochemical composition of the biomass, mainly crude protein, crude fat, crude fiber, and $\mathrm{N}$-free extract, and these four parameters can be used to estimate the $\mathrm{CH}_{4}$ yield from any biomass (Amon et al. 2007). Crude protein and fat are frequently the most important factors and optimal $\mathrm{CH}_{4}$ production occurs at $\mathrm{C} / \mathrm{N}$ ratios of 10 to 30 in the digester (Amon et al. 2007). Thus, high $\mathrm{C} / \mathrm{N}$ biomass feedstock low in crude protein and fat, such as maize and grasses, could benefit by being enriched with crude protein by mixing legume foliage from species like clover or

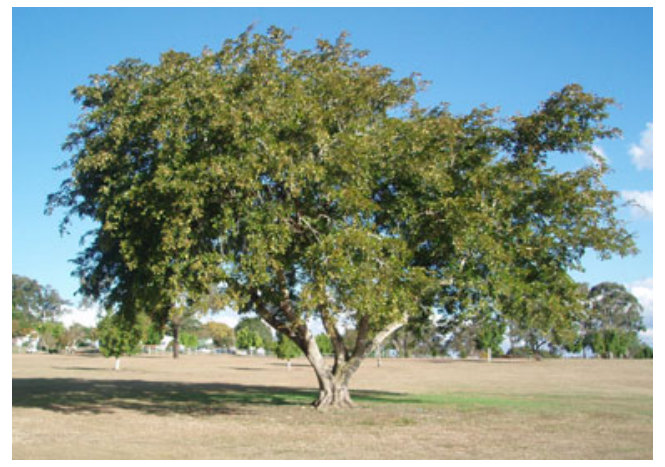

Fig. 14 Mature Pongamia (Millettia) pinnata tree in South East Queensland. Photo: P. Scott, CILR alfalfa to improve efficiencies. But sole crop legume biomass with a high $\mathrm{N}$ content would not be optimal either because the concentration of $\mathrm{NH}_{4}$ in the reactor may become too high and stop the digestion process.

Currently, biogas is produced from monoculture maize feedstock in many European countries, but legume-based energy crops for biogas should be integrated in sustainable crop rotations (Amon et al. 2007), eventually as double cropping systems within the same growing season (Karpenstein-Machan 2001; Fig. 15). Anaerobic digestion is an optimal conversion technology containing legume biomass since the valuable content of $\mathrm{N}, \mathrm{P}$, and other nutrients is exploited efficiently via the digestate biofertilizer.

Conclusion Legume biomass is well suited for the production of biogas when mixed with other species since the $\mathrm{N}$ and other nutrients in the digestate can be used as a valuable biofertilizer.

\subsubsection{Thermochemical conversion for production of heat, syngas, biooil, and biochar}

Combustion of a biomass with a high content of $\mathrm{N}$, such as legumes biomass, is not likely to be a sustainable conversion 
Table 12 Comparisons of the methane $\left(\mathrm{CH}_{4}\right)$ potential of grass or cereal sources to selected legumes and legume containing biomasses

\begin{tabular}{|c|c|c|}
\hline Species & $\mathrm{CH}_{4}$ potential $\left(\mathrm{m}^{3} \mathrm{~kg}^{-1} \text { volatile solids }\right)^{\mathrm{a}}$ & Reference \\
\hline Maize & 0.38 & \multirow[t]{8}{*}{ Banks (2007) } \\
\hline Ryegrass & 0.37 & \\
\hline Alfalfa & 0.34 & \\
\hline Clover spp. & 0.35 & \\
\hline Lupin spp. & 0.33 & \\
\hline Faba bean & 0.36 & \\
\hline Pea & 0.39 & \\
\hline Vetch & 0.28 & \\
\hline Fresh maize & 0.43 & \multirow[t]{3}{*}{ Oleskowicz-Popiel (2010) } \\
\hline Fresh clover & 0.38 & \\
\hline Clover silage & 0.40 & \\
\hline Grasses & 0.34 & \multirow[t]{5}{*}{ Lehtomäki et al. (2008) } \\
\hline Fresh Timothy-red clover ${ }^{\mathrm{b}} \operatorname{mix}(10 \%$ legume $)$ & 0.37 & \\
\hline Red clover & 0.29 & \\
\hline Vetch-oat $^{\mathrm{c}}$ (50\% legume) & 0.41 & \\
\hline Lupin $^{\mathrm{d}}$ & 0.34 & \\
\hline Maize (silage) & 0.39 & \multirow[t]{3}{*}{ Amon et al. (2007) } \\
\hline Fresh grass-clover ( $\%$ legume not determined) & 0.34 & \\
\hline Alfalfa & 0.34 & \\
\hline
\end{tabular}

${ }^{\text {a }}$ Volatile solids: dry biomass-ashes $\left(550^{\circ} \mathrm{C}\right)$

${ }^{\mathrm{b}}$ Phleum pratense-Trifolium pretense

${ }^{\mathrm{c}}$ Vicia sativa-Avena sativa

${ }^{\mathrm{d}}$ Lupinus polyphyllus

technology due to the potential losses of limited nutrients such as $\mathrm{P}$ and $\mathrm{K}$ along with the ash and the formation of nitrogen oxides ( $\mathrm{NO}$ and $\mathrm{NO}_{2}$ ), which have GHG potential similar to $\mathrm{N}_{2} \mathrm{O}$ (Peoples et al. 2004b; Ceotto 2008). Tree legumes such as L. leucocephala, G. sepium, and Acacia spp. are already used as fuel wood and can be important energy sources for households in developing countries (Ryan 1994; Kazakoff et al. 2010; Fig. 16). Key fuel wood characteristics are moisture content and energy density, but consideration should also be made for flame retardants in some species (e.g., Sesbania grandiflora) and if possible also the nutrient cycling aspects

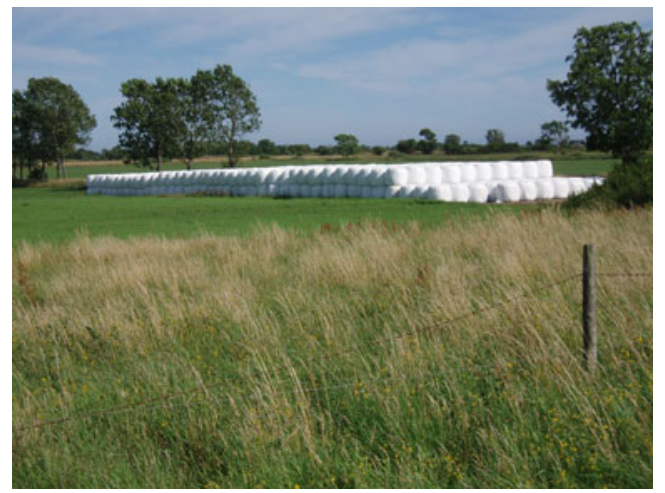

Fig. 15 Grass-legume biomass stored as silage to be used continuously as a feedstock for an on-farm biogas plant. Photo: E. S. Jensen, SLU mentioned above since large amounts of nutrients may be removed from the system with the fuel wood and ash if these are not recycled (Ryan 1994).

Pyrolysis of biomass involves the combustion of the biomass without oxygen and results in syngas, biooil, and biochar. The production ratio of these components depends on the biomass characteristics and the pyrolysis temperature (Bruun et al. 2011). The syngas and biooil can be combusted with oxygen or upgraded to biofuels for vehicles. The biochar, which contain the majority of nutrients except $\mathrm{N}$ and

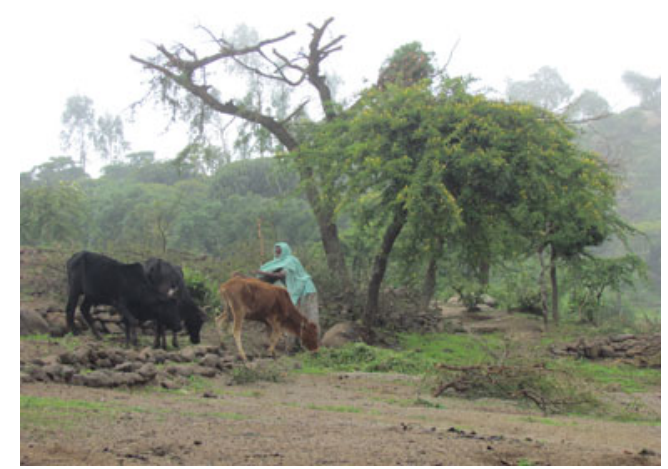

Fig. 16 Multifunctional and multipurpose Acacia abyssinica in an Ethiopian highland (c. $2,000 \mathrm{~m}$ ) village. The tree is grown in field margins and pruned for goat feed (due to its thorny nature) and fuel wood. Photo: E. S. Jensen, SLU 
$\mathrm{S}$, can be used to recycle nutrients and provide long-term $\mathrm{C}$ sequestration in soil since the $\mathrm{C}$ in the biochar is rather recalcitrant to microbial decomposition (Lehmann et al. 2006). Pyrolyzing straw from high biomass soybeans at $500{ }^{\circ} \mathrm{C}$ resulted in around $70 \%$ biooil, $20 \%$ biochar, and $10 \%$ syngas (Boateng et al. 2010). Boateng et al. (2008) found that the pyrolysis of alfalfa stems produced a lower output of biooil, but slightly higher amounts of biochar than soybean, although the oil was found to have a higher energy content.

Conclusions Legume tree or residue biomasses could be used in thermochemical conversion processes, but it is important to consider that the $\mathrm{N}$ and $\mathrm{S}$ may be lost from the system. However, in biorefinery concepts, the final conversion process may be a thermochemical or versatile biochemical process such as anaerobic digestion to efficiently recycle the remaining carbohydrates and nutrients in the digestate.

\subsubsection{Materials and chemicals}

In a biobased economy, there is a requirement to replace products other than energy carriers currently derived from fossil hydrocarbons. Biomass may contribute building blocks for chemicals, biomaterials, and biopharmaceuticals. For example, $56 \mathrm{Tg}$ of textiles were produced worldwide in 1999 of which 54\% was synthetic chemical fibers based on fossil hydrocarbons (Lorek and Lucas 2003). Traditionally, legumes have been considered as a source of dietary oil, protein, and fiber for humans and livestock, but legumes contain many constituents that are essentially similar to other sources of biomass - sugars, amino acids, phytochemicals, lignin, tannins, etc. (Fig. 4) - which can be used as building block chemicals to produce surfactants, biopolymers, glues, and a variety of industrial chemicals which are now produced in petrochemical refineries (De Jong et al. 2010). Some natural products are either found only in legumes or in high concentrations in legumes that are of potential use as nutri- or pharmaceuticals, or biopesticides in addition to industrial purposes, and there could be significant benefits in extracting some of the higher value compounds in a biorefinery (Dixon and Sumner 2003; Duranti et al. 2008). For example, there are several reports of a possible role for the use of legume seed proteins to control metabolic disorders. These include the cholesterol-lowering effect of soybean 7S globulin $\alpha^{\prime}$ subunit and the immobilization of insulin by lupin conglutin $\gamma$ to control glycemia (Magni et al. 2004; Duranti et al. 2008). Legumes also produce isoflavones which reputably have estrogenic, antiangiogenic, antioxidant, and anti-cancer activities, and an ability to prevent osteoporosis and cardiovascular diseases (Dixon and Sumner 2003). Condensed tannins and polyphenols present in legume seed coats are antioxidants with potential health beneficial effects for cardiac health and immunity, and it has recently been reported that phenolic compounds from faba bean can inhibit human cancer cells (Dixon and Sumner 2003; Siah et al. 2011). Triterpene saponin, which is present in alfalfa, deters herbivore grazing, but these saponins also display allelopathic, antimicrobial, and anti-insect activity, which can be used in other contexts such as surfactants and foaming agents (Dixon and Sumner 2003). The variety of food and non-food products that have been successfully developed and marketed from soybean illustrates what may be possible for other legumes.

Conclusion Legumes are known to contain proteins and bioactive substances, which could be extracted in future biorefineries and used as industrial chemicals, food ingredients or pharmaceuticals, surfactants and bioplastics.

\section{Concluding remarks}

Legumes are unique plants. They contribute many different functions and ecosystems services that are of great value for agriculture and society (Jensen and Hauggaard-Nielsen 2003; Crews and Peoples 2004; Peoples et al. 2009b; Köpke and Nemecek 2010; De Faria et al. 2011). Including legume food, forage, and tree crops in farming systems is one approach that can contribute to mitigating climate change. Our review of the literature indicates that the ability of the legumes to fix their own $\mathrm{N}$ via a symbiosis with rhizobia bacteria reduces emissions of fossil energy-derived $\mathrm{CO}_{2}$ and results in lower $\mathrm{N}_{2} \mathrm{O}$ fluxes compared to cropping and pasture systems that are fertilized with industrial N. Less quantitative data are available concerning $\mathrm{N}_{2} \mathrm{O}$ losses from legume residues following a legume phase in a cropping sequence. It was concluded that while the potential losses of $\mathrm{N}_{2} \mathrm{O}$ can be large from leguminous residues containing high concentrations $\mathrm{N}$ such as nodules, or fresh foliage, the contribution of $\mathrm{N}_{2} \mathrm{O}$ emissions from senesced vegetative residues remaining after grain harvest of a crop legume can be small. Further work is needed to better understand how the management and quality of legume residues affects $\mathrm{N}_{2} \mathrm{O}$ emissions in subsequent crops.

In addition to legumes resulting in lower GHG emissions, they also appear to play a key role in soil $\mathrm{C}$ sequestration. The inclusion of herbaceous legumes in pastures, and either as sole crops, green- or brown-manures, cover-crops, or intercrops in reduced tillage cropping systems, has been shown to enhance soil $\mathrm{C}$ accumulation. Woody perennial legume species have also been demonstrated to be extremely useful for revegetating cleared and degraded land to replenish soil organic $\mathrm{C}$ stocks.

In the short term, it is unlikely that sole crop annual legumes will be used as biorefinery feedstock due to their relatively low DM yield. Legumes are important compo- 
nents of future diversified and sustainable cropping systems, which are not in direct competition for land with food production. Many legumes can be produced on marginal/ surplus lands and on degraded or drastically disturbed soils. Perennial legumes (alfalfa, clover, and various tree and shrub species) could have unique roles in generating biomass for biorefineries, without the requirement for $\mathrm{N}$ fertilization either as sole crops or in mixtures with grasses.

Advances in conversion/biorefinery technologies will be required which can add value to the by-products of energy generation by extracting and exploiting the high protein content of legume biomass. Examples of potential technologies and products suited for legume biomass include protein extraction for feed (e.g., soybean cake) or pharmaceuticals, renewable materials production, and anaerobic digestion for $\mathrm{CH}_{4}$ production with the simultaneous production of a biofertilizer containing nutrients for recycling.

Residues from arable crops provide an essential function in maintaining soil fertility, preventing soil erosion and structure in arable soil (Lal and Pimentel 2007). Consequently, the use of legume biomass for bioenergy, materials, and chemicals represents a significant trade-off since the contribution of legume residues to soil organic fertility and $\mathrm{C}$ sequestration would be significantly reduced. National strategies for using straw and other residues for biofuels will need to identify the regions that have soils with sufficient organic matter levels to allow the temporary utilization of the straw/stover for bioenergy that are also at low risk of erosion (Nelson 2002). The huge world acreage of soybean potentially could generate massive amounts of organic residues. In the USA, McMurtrey et al. (2005) showed that no soybean residues could be sustainably removed after growing conventional soybean types with conventional tillage practice, whereas between $7 \%$ and $30 \%$ of the residues could be removed with reduced tillage and zero-tillage scenarios, respectively.

Future sustainable agricultural systems require novel management and plant breeding solutions to assist society with climate change mitigation options for producing biofuels, materials, and chemicals. One of the key paradigms for future sustainable agriculture is multifunctionality of system and crops. Agriculture will need to supply several services from the use of the same piece of land, and the key principle to obtain this is diversity in time and space, involving cropping systems as well as crop species. Thus, legume species, with their multiple arrays of potential ecosystems services combined with their ability to reduce GHG emissions and encourage soil C sequestration, should be given careful consideration as important components of future sustainable food, fiber, and energy production systems for human prosperity.

Acknowledgments Erik S. Jensen wishes to acknowledge that participation in the Fifth International Food Legumes Research Conference helped facilitate the preparation of this review. Mark B.
Peoples is indebted for the support of the Grains Research and Development Corporation (GRDC) to continue research into the role of legumes in Australian farming systems. Peter M. Gresshoff thanks the Australian Research Council (ARC) for a Centre of Excellence grant, the University of Queensland Strategic Fund for continued support, Dr. Paul Scott for academic input, and the Bioenergy Research Pty Ltd for commercial partnership in Pongamia-related research efforts. Malcolm J. Morrison wishes to thank Agriculture and Agri-Food Canada for financial support, Dr. Ed Gregorich and Pat St George from Agriculture and Agri-Food Canada who assisted in the collection of the $\mathrm{N}_{2} \mathrm{O}$ data depicted in Fig. 2 along with Brian Couture and Randy Hodgins for field work and technical support.

\section{References}

Amon T, Amon B, Kryvoruchko V, Machmüller A, Hopfner-Sixt K, Bodiroza V, Hrbek R, Fridel J, Pötsch E, Wagentristl H, Schreiner M, Zollitsch W (2007) Methane production through anaerobic digestion of various energy crops grown in sustainable crop rotations. Biores Technol 98:3204-3212

Angus JF, Gaul RR, Peoples MB, Stapper M, van Hawarden AF (2001) Soil water extraction by dryland crops, annual pastures and lucerne in south-eastern Australia. Aust J Agric Res 52:183-192

Armstrong RD, Kickoff BJ, Millar G, Whitbread AM, Standley J (1999) Changes in soil chemical and physical properties following legumes and opportunity cropping on a cracking clay soil. Aust J Exp Agric 39:445-456

Arrouays D, Deslais W, Badeau V (2001) The carbon content of topsoil and its geographical distribution in France. Soil Use Manag 17:7-11

Atkins CA (1984) Efficiencies and inefficiencies in the legume/ Rhizobia symbiosis - a review. Plant Soil 82:273-284

Aulakh MS, Khera TS, Doran JW, Bronson KF (2001) Denitrification, $\mathrm{N}_{2} \mathrm{O}$ and $\mathrm{CO}_{2}$ fluxes in rice-wheat cropping system as affected by crop residues, fertilizer $\mathrm{N}$ and legume green manure. Biol Fertil Soils 34:375-389

Baggs EM, Stevenson M, Pihlatie M, Regar A, Cook H, Cadisch G (2003) Nitrous oxide emissions following application of residues and fertilizer under zero and conventional tillage. Plant Soil 254:361-370

Baker JM, Ochsner TE, Venterea RT, Griffis TJ (2007) Tillage and carbon sequestration-what do we really know? Agric Ecosyst Environ 118:1-5

Banks C (2007) Renewable energy from crops and agrowastes (CROPGEN). Final report. 32 p. http://www.cropgen.soton.ac.uk/ deliverables/CROPGEN PFAR2007.pdf (accessed 24 February 2011)

Barthès B, Azontonde A, Blanchart E, Girardin C, Villenave C, Lesaint S, Oliver R, Feller C (2004) Effect of a legume cover crop (Mucuna pruriens var. utilis) on soil carbon in an Ultisol under maize cultivation in southern Benin. Soil Use Manag 20:231-239

Barton L, Kiese R, Gatter D, Butterbach-Bahl K, Buck R, Hinz C, Murphy DV (2008) Nitrous oxide emissions from a cropped soil in a semi-arid climate. Global Change Biol 14:177-192

Barton L, Murphy DV, Kiese R, Butterbach-Bahl K (2010) Soil nitrous oxide and methane fluxes are low from a bioenergy crop (canola) grown in a semi-arid climate. Global Change Biol Bioenergy 2:1-15

Barton L, Butterbach-Bahl K, Kiese R, Murphy DV (2011) Nitrous oxide fluxes from a grain-legume crop (narrow-leafed lupin) grown in a semiarid climate. Global Change Biol 17:11531166 
Bayer C, Mielniczuck J, Amado TJC, Martin-Neto L, Fernandes SBV (2000) Organic matter storage in a sandy clay loam Acrisol affected by tillage and cropping systems in southern Brazil. Soil Tillage Res 54:101-109

Bergersen FJ, Brockwell J, Gault RR, Morthorpe L, Peoples MB, Turner GL (1989) Effects of available soil nitrogen and rates of inoculation on nitrogen fixation by irrigated soybeans and evaluation of $\delta^{15} \mathrm{~N}$ methods for measurement. Aust J Agric Res 40:761-780

Bertelsen F, Jensen ES (1992) Gaseous nitrogen losses from field plots grown with pea (Pisum sativum L.) or spring barley (Hordeum vulgare L.) estimated by ${ }^{15} \mathrm{~N}$ mass balance and acetylene inhibition techniques. Plant Soil 142:287-295

Bessou C, Ferchaud F, Gabrielle B, Mary B (2010) Biofuels, greenhouse gases and climate change. A review. Agron Sustain Dev. doi:10.1051/agro/2009039

Blasing TJ (2010) Recent greenhouse gas concentrations. Carbon Dioxide Information Analysis Center Oak Ridge National Laboratory. doi:10.3334/CDIAC/atg.032; http://cdiac.ornl.gov/ pns/current_ghg.html (accessed 1 July 2010).

Boateng AA, Mullen CA, Goldberg NM, Hicks K, Devine TE, Lima IM, McMurtrey JE (2010) Sustainable production of bioenergy and biochar from the straw of high-biomass soybeans lines via fast-pyrolysis. Environ Prog Sustain Energ 29:175-183

Boateng AA, Mullen CA, Goldberg NM, Hicks KB, Jung HG, Lamb JF (2008) Production of bio-oil from alfalfa stems by fluidizedbed fast pyrolysis. Ind Eng Chem Res 47:4115-4122

Boddey RM, Xavier DF, Alves BJR, Urquiaga S (2003) Brazilian agriculture: the transition to sustainability. J Crop Prod 9:593-621

Boddey RM, de Soares B, Alves BJR, Urquiaga S (2008) Bio-ethanol production in Brazil. In: Pimentel D (ed) Biofuels, solar and wind as renewable energy systems: benefits and risks. Springer, New York, pp 321-356

Boddey RM, Alves BJR, Soares LHB, Jantalia CP, Urquiaga S (2009) Biological nitrogen fixation and the mitigation of greenhouse gas emissions. In: Emerich DW, Krishnan HB (eds) Agronomy Monograph 52. Nitrogen Fixation in Crop Production, Am. Soc. Agron., Crop Sci. Soc. Am., and Soil Sci. Soc Am. Madison, Wisconsin, USA, pp. 387-413

Boddey RM, Jantalia CP, Zanatta JA, Conceição PC, Bayer C, Mielniczuk J, Dieckow J, dos Santos HP, Denardin JE, Aita C, Alves BJR, Urquiaga S (2010) Carbon accumulation at depth in Ferralsols under zero-till subtropical agriculture in southern Brazil. Global Change Biol 16:784-795

Bouwman AF (1996) Direct emissions of nitrous oxide from agricultural soils. Nutr Cycl Agroecosyst 46:53-70

Brehmer B, Struik PC, Sanders J (2008) Using an energetic and exergetic life cycle analysis to assess the best application of legumes within a biobased economy. Biomass Bioenerg 32:1175-1186

Breitenbeck GA, Bremner JM (1989) Ability of free-living Bradyrhizobium japonicum to denitrify nitrate in soils. Biol Fertil Soils 7:219-224

Bremer E, van Kessel C (1992) Seasonal microbial biomass dynamics after addition of lentil and wheat residues. Soil Sci Soc Am J 56:1141-1146

Bruun EW, Hauggaard-Nielsen H, Ibrahim N, Egsgaard H, Ambus P, Jensen PA, Dam-Johansen K (2011) Influence of fast pyrolysis temperature on biochar labile fraction and short-term carbon loss in a loamy soil. Biomass Bioenerg 35:1182-1189

Carroll BJ, McNeil DL, Gresshoff PM (1985) Isolation and properties of soybean mutants which nodulate in the presence of high nitrate concentrations. Proc Natl Acad Sci USA 82:4162-4166

Ceotto E (2008) Grasslands for bionenergy production. A review. Agron Sustain Dev 28:47-55

Chaer GM, Resende AS, de Balieiro FC, Boddey RM (2011) Nitrogen-fixing legume tree species for the reclamation of severely degraded lands in Brazil. Tree Physiol 31:139-149
Chalk PM (1998) Dynamics of biologically fixed N in legume-cereal rotations: a review. Aust J Agric Res 49:303-316

Chan KY (1997) Consequences of changes in particulate organic carbon in vertisols under pasture and cropping. Soil Sci Soc Am J 61:1376-1382

Chan KY, Conyers MK, Li GD, Helyar KR, Poile G, Oates A, Barchia IM (2011) Soil carbon dynamics under different cropping and pasture management in temperate Australia: results of three longterm experiments. Soil Res 49:320-328

Chen S, Huang Y, Zou J (2008) Relationship between nitrous oxide emission and winter wheat production. Biol Fertil Soils 44:985-989

Cherubini F, Jungmeir G, Wellisch M, Wilke M, Skiadas I, Van Ree R, de Jong E (2009) Towards a common classification approach for biorefinery systems. Biofuels Bioprod Bioref 3:534-546

Christopher SF, Lal R (2007) Nitrogen management affects carbon sequestration in North American cropland soils. Crit Rev Plant Sci 26:45-64

Ciampitti IA, Ciarlo EA, Conti ME (2008) Nitrous oxide emissions from soil during soybean [(Glycine $\max (\mathrm{L}$.) Merrill] crop phenological stages and stubbles decomposition period. Biol Fertil Soils 44:581-588

Cleveland CC, Liptzin D (2007) C:N:P stoichiometry in soil: is there a "Redfield ratio" for the microbial biomass? Biogeochem 85:235252

Conant RT, Paustian K, Elliot ET (2001) Grassland management and conversion into grassland: effects on soil carbon. Ecol Applic 11:343-355

Crews TE, Peoples MB (2004) Legume versus fertilizer sources of nitrogen: ecological tradeoffs and human needs. Agric Ecosyst Environ 102:279-297

Crews TE, Peoples MB (2005) Can the synchrony of nitrogen supply and crop demand be improved in legume and fertilizer-based agroecosystems? A review. Nutr Cycl Agroecosyst 72:101-120

Dalal RC, Chan KY (2001) Soil organic matter in rainfed cropping systems of the Australian cereal belt. Aust J Soil Res 39:435-464

Dalal RC, Strong WM, Weston EJ, Cooper JE, Lehane KJ, King AJ, Chicken CJ (1995) Sustaining productivity of a vertisol at Warra, Queensland, with fertilizers, no-tillage, or legumes. 1. Organic matter status. Aust J Exp Agric 35:903-913

Dale BE (1983) Biomass refining: protein and ethanol from alfalfa. Ind Eng Chem Prod Res Dev 22:466-472

Danish Feed Analysis (2005) Feed tables 2005. Eds. J. Møller. 49 p. (in Danish)

De Faria SM, Resende AS, Saggin Júnior OJ, Boddey RM (2011) Exploiting mycorrhizae and rhizobium symbioses to recover seriously degraded soils. In: Polacco JC, Todd CD (eds) Ecological aspects of plant nitrogen metabolism. WileyBlackwell, New York, pp 195-214

De Jong E, van Ree R, Sanders JPM, Langeveld JWA (2010) Biorefineries: giving value to sustainable biomass use. In: Langeveld H, Sanders J, Meeusen M (eds) The biobased economy - biofuels, materials and chemicals in the post-oil era. Earthscan, London

Dean W (1995) With Broadax and Firebrand: the destruction of the Brazilian Atlantic Forest. University of California Press, Berkeley

Diekow J, Mielniczuk J, Knicker H, Bayer C, Dick DP, Kogel-Knabner I (2005) Soil C and N stocks as affected by cropping systems and nitrogen fertilization in a southern Brazil Acrisol managed under notillage for 17 years. Soil Tillage Res 81:87-95

Dixon RA, Sumner LW (2003) Legume natural products: understanding and manipulating complex pathways for human and animal health. Plant Physiol 131:878-885

Duke JA (1981) Handbook of legumes of world economic importance. Plenum, New York 
Duke JA (1983) Handbook of Energy Crops. http://www.hort.purdue. edu/newcrop/duke energy/dukeindex.html (Accessed 23 February 2011).

Duranti M, Consonni A, Magni C, Sessa F, Scarafoni A (2008) The major proteins of lupin seed: characterisation and molecular properties for use as functional and nutraceutical ingredients. Trends Food Sci Technol 19:624-633

Elbersen HW, Bindraban PS, Blaauw R, Jongman R (2010) Biodiesel from Brazil. In: Langeveld H, Sanders J, Meeusen M (eds) The biobased economy-biofuels, materials and chemicals in the post-oil era. Earthscan, London, pp 283-301

Entz MH, Bullied WJ, Forster DA, Gulden R, Vessey JK (2001) Extraction of subsoil nitrogen by alfalfa, alfalfa-wheat and perennial grass systems. Agron J 93:495-503

Eswaran H, Vandenberg E, Reich P (1993) Organic carbon in soils of the world. Soil Sci Soc Am J 57:192-194

Eurostat (2007) Gas and electric market statistics. European Communities, Office for Official Publications of the European Communities, Luxembourg

Evans J, Scott G, Lemerle D, Kaiser A, Orchard B, Murray GM, Armstrong EL (2003) Impact of legume 'break' crops on the residual amount and distribution of soil mineral nitrogen. Aust J Agric Res 54:763-776

Fairley P (2011) Next generation biofuels. Nature 474:S2-S5

FAOStat (2010) http://faostat.fao.org/ (Accessed 20 September 2010)

Ferguson BJ, Indrasumunar A, Hayashi S, Lin M-H, Lin Y-H, Reid DE, Gresshoff PM (2010) Molecular analysis of legume nodule development and autoregulation. $\mathrm{J}$ Integr Plant Biol 52:61-76

Fillery IRP (2001) The fate of biologically fixed nitrogen in legumebased dryland farming systems: a review. Aust J Exp Agric 41:361-381

Finke RL, Harper JE, Hageman RH (1982) Efficiency of nitrogen assimilation by $\mathrm{N}_{2}$-fixing and nitrate-grown soybean plants (Glycine max [L.] Merr.). Plant Physiol 70:1178-1184

Fisher MJ, Rao IM, Ayarza MA, Lascono CE, Sanz JI, Thomas RJ, Vera RR (1994) Carbon storage by introduced deep-rooted grasses in South American savannas. Nature 371:236-238

Fisher MJ, Braz SP, dos Santos RSM, Urquiaga S, Alve BJR, Boddey RM (2007) Another dimension to grazing systems: soil carbon. Trop Grassl 41:65-83

Franco AA, de Faria SM (1997) The contribution of $\mathrm{N}_{2}$-fixing tree legumes to land reclamation and sustainability in the tropics. Soil Biol Biochem 29:897-903

Freixo AA, de Machado PLOA, dos Santos HP, Silva CA, de Fadigas FS (2002) Soil organic carbon and fractions of a Rhodic Ferrasol under the influence of tillage and crop rotation systems in southern Brazil. Soil Tillage Res 64:221-230

Gaiser T, Stahr K, Bernard M, Kang BT (2011) Changes in soil carbon fractions in a tropical Acrisol as influenced by the addition of different residue materials. Agroforest Syst. doi:10.1007/s10457011-9417-0

Galiana A, Gnahoua GM, Chaumont J, Lesueur D, Prin Y, Mallet B (1998) Improvement of nitrogen fixation in Acacia mangium through inoculation with rhizobium. Agroforest Syst 40:297307

Gan Y, Liang C, Wang X, McConkey B (2011) Lowering carbon footprint of durum wheat by diversifying cropping systems. Field Crops Res 122:199-206

Garcia-Plazaola JI, Becerril JM, Arrese-Igor C, Hernandez A, Gonzalez-Murua C, Aparicio-Tejo PM (1993) The contribution of Rhizobium meliloti to soil denitrification. Plant Soil 157:207213

Gardner JB, Drinkwater LE (2009) The fate of nitrogen in grain cropping systems: a meta-analysis of ${ }^{15} \mathrm{~N}$ field experiments. Ecol Appl 19:2167-2184
Goossens A, De Visscher A, Boeckx P, Van Cleemput O (2001) Twoyear field study on the emission of $\mathrm{N}_{2} \mathrm{O}$ from coarse and middletextured Belgian soils with different land use. Nutr Cycl Agroecosyst 60:23-34

Grace PR, Oades JM, Keith H, Hancock TW (1995) Trends in wheat yields and soil organic carbon in the permanent rotation trial at the Waite Agricultural Research Institute, South Australia. Aust J Exp Agric 35:857-864

Gregorich EG, Drury CF, Baldock JA (2001) Changes in soil carbon under long-term maize in monoculture and legume-based rotation. Can J Soil Sci 81:21-31

Gresshoff PM, Lohar D, Chan PK, Biswas B, Jiang Q, Reid D, Ferguson B, Stacey G (2009) Genetic analysis of ethylene regulation of legume nodulation. Plant Signal Behav 4:9

Hammerschlag R (2006) Ethanols energy return on investment: a survey of the literature 1990-present. Environ Sci Technol 40:1744-1750

Hauggaard-Nielsen H, Ambus P, Jensen ES (2003) The comparison of nitrogen use and leaching in sole cropped versus intercropped pea and barley. Nutr Cycl Agroecosyst 65:289-300

Hauggaard-Nielsen H, Gooding M, Ambus P, Corre-Hellou G, Crozat Y, Dahlmann C, Dibet A, von Fragstein P, Pristeri A, Monti M, Jensen ES (2009) Pea-barley intercropping for efficient symbiotic $\mathrm{N}_{2}$-fixation, soil $\mathrm{N}$ acquisition and use of other nutrients in European organic cropping systems. Field Crop Res 113:64-71

Heenan DP, McGhie WJ, Thompson F, Chan KY (1995) Decline in soil organic carbon and total nitrogen in relation to tillage, stubble management and rotation. Aust J Exp Agric 35:877-884

Helgason BL, Janzen HH, Chantigny MH, Drury CF, Ellert BH, Gregorich EG, Lemke RL, Pattey E, Rochette P, Wagner-Riddle $\mathrm{C}$ (2005) Toward improved coefficients for predicting direct $\mathrm{N}_{2} \mathrm{O}$ emissions from soil in Canadian agroecosystems. Nutr Cycl Agroecosyst 72:87-99

Hénault C, Devis X, Lucas JL, Germon JC (1998) Influence of different agricultural practices (type of crop, form of $\mathrm{N}$-fertilizer) on soil nitrous oxide emissions. Biol Fertil Soils 27:299-306

Herridge DF, Marcellos H, Felton WL, Turner GL, Peoples MB (1995) Chickpea increases soil-N fertility in cereal systems through nitrate sparing and $\mathrm{N}_{2}$ fixation. Soil Biol Biochem 27:545-551

Herridge DF, Peoples MB, Boddey RM (2008) Marschner review: global inputs of biological nitrogen fixation in agricultural systems. Plant Soil 311:1-18

Hoyle FC, Baldock JA, Murphy DV (2011) Soil organic carbon—role in Australian farming systems. In: Tow P, Cooper I, Partridge I, Birch $\mathrm{C}$ (eds) Rainfed farming systems. Springer, Heidelberg, in press

IAASTD (2009) Executive summary of the synthesis report. International Assessment of Agricultural Knowledge, Science and Technology for Development. Intergovernmental plenary Johannesburg, South Africa (7-11 April 2008). 34 p

IBGE (2011) Instituto Brasileiro de Geografia e Estatística. Retrieved August 2011, from http://www.sidra.ibge.gov.br/bda/default.asp? $\mathrm{t}=5 \& \mathrm{z}=\mathrm{t} \& \mathrm{o}=1 \& \mathrm{u} 1=1 \& \mathrm{u} 2=1 \& \mathrm{u} 3=1 \& \mathrm{u} 4=1 \& \mathrm{u} 5=1 \& \mathrm{u} 6=1 \& \mathrm{u} 7=$ $1 \& u 8=1 \& u 9=3 \& u 10=1 \& u 11=26674 \& u 12=1 \& u 13=1 \& u 14=1$ (Acessed 14 August 2011)

IEA (2009) World Energy outlook 2008. International Energy Agency. 568 p. IEA, Paris

IFA (2010) International Fertilizer Industry Association, Paris France. http://www.fertilizer.org/ifa/Home-Page/STATISTICS (Accessed 20 August 2010)

IPCC (1996) Guidelines for National Greenhouse Gas Inventories? Intergovernmental Panel on Climate Change (IPCC)

IPCC (2000) The science bases. http://www.ipcc.ch (Accessed 22 August 2010)

IPCC (2006) IPCC Guidelines for National Greenhouse Gas Inventories, Prepared by the National Greenhouse Gas Inventories Programme, Inst. for Global Strategies (IGES), Hayama 
IPCC (2007) Climate change 2007: Synthesis report. Summary for Policymakers. Intergovernmental Panel on Climate Change (IPCC)

Jantalia CP, dos Santos HP, Urquiaga S, Boddey RM, Alves BJR (2008) Fluxes of nitrous oxide from soil under different crop rotations and tillage systems in the south of Brazil. Nutr Cycl Agroecosyst 82:161-173

Jenkinson DS (2001) The impact of humans on the nitrogen cycle, with focus on temperate agriculture. Plant Soil 228:3-15

Jensen ES (1989) The role of pea cultivation in the nitrogen economy of soils and succeeding crops. In: Planquaert P, Haggar R (eds) Legumes in farming systems. Kluwer, Dordrecht, pp 3-15

Jensen ES, Hauggaard-Nielsen H (2003) How can increased use of biological $\mathrm{N}_{2}$ fixation in agriculture benefit the environment? Plant Soil 252:177-186

Jensen ES, Peoples MB, Hauggaard-Nielsen H (2010) Faba bean in cropping systems. Field Crops Res 115:203-216

Jones SK, Rees RM, Skiba UM, Ball BC (2007) Influence of organic and mineral $\mathrm{N}$ fertiliser on $\mathrm{N}_{2} \mathrm{O}$ fluxes from a temperate grassland. Agric Ecosyst Environ 121:74-83

Kamp T, Steindl H, Hantschel RE, Beese F, Munch J-C (1998) Nitrous oxide emissions from a fallow and wheat field as affected by increased soil temperatures. Biol Fertil Soils 27:307-314

Karpenstein-Machan M (2001) Sustainable cultivation concepts for domestic energy production from biomass. Crit Rev Plant Sci 20:1-14

Kaschuk G, Kuyper TW, Leffelaar PA, Hungria M, Giller KE (2009) Are the rates of photosynthesis stimulated by the carbon sink strength or rhizobial and arbuscular mycorrhizal symbioses? Soil Biol Biochem 41:1233-1244

Kaschuk G, Hungria M, Leffelaar PA, Giller KE, Kuyper TW (2010) Differences in photosynthetic behaviour and leaf senescence of soybean (Glycine max [L.] Merrill) dependent on $\mathrm{N}_{2}$ fixation or nitrate supply. Plant Biol 12:60-69

Kazakoff SH, Gresshoff PM, Scott PT (2011) Pongamia pinnata, a sustainable feedstock for biodiesel production. In: Halford N, Karp A (eds) Energy crops. Royal Society of Chemistry, London, pp. 233-254

Kilian S, Werner D (1996) Enhanced denitrification in plots of $\mathrm{N}_{2^{-}}$ fixing faba beans compared to plots of a non-fixing legume and non-legumes. Biol Fert Soils 21:77-83

Kindler R, Siemens J, Kaiser K, Walmsley DC, Bernhofer C, Buchmann N, Cellier P, Eugster W, Gleixner G, Grŭnswald T, Heim A, Ibrom A, Jones SK, Jones M, Klumpp K, Kutsch W, Larsen KS, Lehuger S, Loubet B, McKenzie R, Moors E, Osborne B, Pilegaard K, Rebmann C, Saunders M, Schmidt I, Schrumpf M, Seyfferth J, Skib U, Soussana JF, Sutton MA, Tefs C, Vowinckels B, Zeeman M, Kaupenjohann M (2011) Dissolved carbon leaching from soil is a crucial component of the net ecosystem carbon balance. Glob Change Biol 17:1167-1185

Kirkby CA, Kirkegaard JA, Richardson AE, Wade LJ, Blanchard C, Batten G (2011) Stable soil organic matter: a comparison of CNPS ratios in Australian and international soils. Geoderma 163:197-208

Kirkegaard J, Christen O, Krupinsky J, Layzell D (2008) Break crop benefits in temperate wheat production. Field Crops Res 107:185-195

Kirkegaard JA, Peoples MB, Angus JE, Unkovich MJ (2011) Diversity and evolution of rainfed farming systems in Southern Australia. In: Tow P, Cooper I, Partridge I, Birch C (eds) Rainfed farming systems. Springer, Dordrecht, The Netherlands, pp 715-754

Klumpp K, Fontaine S, Arrard E, Le Roux X, Gleixner G, Soussana JF (2009) Grazing triggers soil carbon loss by altering plant roots and their control on soil microbial community. J Ecol 97:876-885

Klumpp K, Bloor JMG, Ambus P, Soussana JF (2011) Effect of clover density on $\mathrm{N}_{2} \mathrm{O}$ emissions and plant-soil $\mathrm{N}$ transfers in a fertilised upland pasture. Plant Soil 343:97-107
Koegel RG, Sreenath HK, Straub RJ (1999) Alfalfa fibre as a feedstock for ethanol and organic acids. App Biochem Biotech 77-79:110-115

Köpke U, Nemecek T (2010) Ecological services of faba bean. Field Crops Res 115:217-233

Krupnik TJ, Six J, Ladha JK, Paine MJ, van Kessel C (2004) An assessment of fertilizer nitrogen recovery efficiency by grain crops. In: Mosier AR, Syers KJ, Freney JR (eds) Agriculture and the nitrogen cycle, the Scientific Committee on Problems of the Environment (SCOPE). Island, Covelo, pp 193-207

Kumar K, Goh KM (2000) Crop residues and management practices: effects on soil quality, soil nitrogen dynamics, crop yield, and nitrogen recovery. Adv Agron 68:197-319

Lal R (2004) Soil carbon sequestration to mitigate climate change. Geoderma 123:1-22

Lal R, Pimentel D (2007) Biofuels from crop residues. Soil Tillage Res 93:237-238

Lamb JFS, Sheaffer CC, Samac DA (2003) Population density and harvest maturity effects on leaf and stem yield in alfalfa. Agron J 295:635-641

Langeveld JWA, Sanders JPM (2010) General introduction. Chapter 1. In: Langeveld H, Sanders J, Meeusen M (eds) The biobased economy-biofuels, materials and chemicals in the post-oil era. Earthscan, London, pp 3-18

Lefroy EC, Stirzaker RJ, Pate JS (2001) The influence of tagasaste (Chamaecytisus profliferus Link.) trees on the water balance of an alley cropping system on deep sand in south-western Australia. Aust J Agric Res 52:235-246

Lehmann J, Gaunt J, Rondon M (2006) Bio-char sequestration in terrestrial ecosystems - a review. Mitig Adapt Strat Glob Change 11:403-427

Lehtomäki A, Viinikainen TA, Rintala JA (2008) Screening boreal energy crops and crop residues for methane biofuels production. Biomass Bioenerg 32:541-550

Lemke RL, Zhong Z, Campbell CA, Zentner R (2007) Can pulse crops play a role in mitigating greenhouse gases from North American agriculture? Agron J 99:1719-1725

Lorek S, Lucas R (2003) Towards sustainable market strategies. A case study on eco-textiles and green power. Wupperthal Institute Report no. 130, $68 \mathrm{p}$

Lupwayi NZ, Kennedy AC (2007) Grain legumes in Northern Great Plains: impacts on selected biological soil processes. Agron J 99:1700-1709

Lægreid M, Bøckman OC, Kaarstad O (1999) Agriculture, fertilizers and the environment. CABI, Wallingford

Mabee W, Saddler J, Nielsen C, Nielsen LH, Jensen ES (2006) Renewable-based fuels for transport. In Larsen H, Petersen LS (eds) Risø Energy Report 5. Renewable Energy for Power and transport. pp 47-50. ISBN 87-550-3515-9, Risø National Laboratory, Denmark

Macedo MO, Resende AS, Garcia PC, Boddey RM, Jantalia CP, Urquiaga S, Campello EFC, Franco AA (2008) Changes in soil C and $\mathrm{N}$ stocks and nutrient dynamics 13 years after recovery of degraded land using leguminous nitrogen-fixing trees. Forest Ecol Manag 255:1516-1524

Magid J, Henriksen O, Thorup-Kristensen K, Mueller T (2001) Disproportionately high $\mathrm{N}$-mineralisation rates from green manures at low temperatures - implications for modelling and management in cool temperate agro-ecosystems. Plant Soil 228:73-82

Magni C, Sessa F, Accardo E, Vanoni M, Morazzoni P, Scarafoni A, Duranti M (2004) Conglutin $\gamma$, a lupin seed protein, binds insulin in vitro and reduces plasma glucose levels of hyperglycaemic rats. J Nutr Biochem 15:646-650

Mahmood T, Ali R, Malik KA, Shamsi SRA (1998) Nitrous oxide emissions from an irrigated sandy-clay loam cropped to maize and wheat. Biol Fertil Soils 27:189-196 
McCallum MH, Kirkegaard JA, Green T, Cresswell HP, Davies SL, Angus JF, Peoples MB (2004) Improved subsoil macroporosity following perennial pastures. Aust J Exp Agric 44:299-307

McMurtrey JE, Daughtry CST, Devine TE, Corp LA (2005) Spectral detection of crop residues for soil conservation from conventional and large biomass soybeans. Agron Sustain Dev 25:25-33

Minchin FR, Pate JS (1973) The carbon balance of a legume and the functional economy of its root nodules. J Expl Bot 24:259-271

Minchin FR, Summerfield RJ, Neves MCP (1980) Carbon metabolism, nitrogen assimilation, and seed yield of cowpea (Vigna unquiculata L. Walp.) grown in an adverse temperature regime. J Expl Bot 31:1327-1345

Mortensen MC, Schuman GE, Ingram LJ (2004) Carbon sequestration in rangelands interseeded with yellow-flowering alfalfa (Medicago sativa ssp. Falcate). Environ Manage 33:S475-S481

Mosier A (2001) Exchange of gaseous nitrogen compounds between agricultural systems and the atmosphere. Plant Soil 228:17-27

Munier-Jolain NG, Salon C (2005) Are the carbon costs of seed production related to the quantitative and qualitative performance? An appraisal for legumes and other crops. Plant Cell Environ 28:1388-1395

Murphy DV, Fillery IRP, Sparling GP (1998) Seasonal fluctuations of gross $\mathrm{N}$ mineralisation, ammonium consumption, and microbial biomass in a Western Australian soil under different land uses. Aust J Agric Res 49:523-535

Möller K, Stinner W, Deuker A, Leitholf G (2008) Effects of different manuring systems with and without biogas digestion on nitrogen cycle and crop yield in mixed organic farming systems. Nutr Cyc Agroecosyst 82:209-232

Nelson RG (2002) Resource assessment and removal analysis for corn stover and wheat straw in the Eastern and Midwestern United States. Rainfall and wind-induced soil erosion methodology. Biomass Bioenerg 22:349-363

Nemecek T, von Richthofen J-S, Dubois G, Casta P, Charles R, Pahl H (2008) Environmental impacts of introducing grain legumes into European crop rotations. Eur J Agron 28:380 393

Nichols NN, Dien BS, Wu YV, Cotta MA (2005) Ethanol fermentation of starch from field peas. Cereal Chem 82:554-558

Novalin S, Zweckmair T (2008) Renewable resources-green biorefinery: separation of valuable substances from fluid-fractions by means of membrane technology. Biofuels Bioprod Bioref $3: 20-27$

O'Hara GW, Daniel RM (1985) Rhizobial denitrification: a review. Soil Biol Biochem 17:1-9

Oleskowicz-Popiel P (2010) Biogas and bioethanol production in organic farming. $\mathrm{PhD}$ thesis, Risø National Laboratory for Sustainable Energy, Risø-PhD-64(EN), ISBN 978-87-550-38394. 47 p. Risø DTU

Osborne CS, Peoples MB, Janssen PH (2010) Exposure of soil to a low concentration of hydrogen elicits a reproducible, single member shift in the bacterial community. Appl Environ Microbiol 76:1471-1479

Parkin TB, Kaspar TC (2006) Nitrous oxide emissions from cornsoybean systems in the Midwest. J Environ Qual 35:1496-1506

Pate JS, Layzell DB, Atkins CA (1979) Economy of carbon and nitrogen in a nodulated and nonnodulated $\left(\mathrm{NO}_{3}\right.$-grown) legume. Plant Physiol 64:1083-1088

Peoples MB, Baldock JA (2001) Nitrogen dynamics of pastures: nitrogen fixation inputs, the impact of legumes on soil nitrogen fertility, and the contributions of fixed nitrogen to Australian farming systems. Aust J Exp Agric 41:327-346

Peoples MB, Herridge DF (1990) Nitrogen fixation by legumes in tropical and subtropical agriculture. Adv Agron 44:155-223
Peoples MB, Herridge DF, Ladha JK (1995a) Biological nitrogen fixation: an efficient source of nitrogen for sustainable agricultural production? Plant Soil 174:3-28

Peoples MB, Lilley DM, Burnett VF, Ridley AM, Garden DL (1995b) Effects of lime and superphosphate to acid soils on growth and $\mathrm{N}_{2}$ fixation by subterranean clover in mixed pasture swards. Soil Biol Biochem 27:663-671

Peoples MB, Palmer B, Lilley DM, Duc LM, Herridge DF (1996) Application of ${ }^{15} \mathrm{~N}$ and xylem ureide methods for assessing $\mathrm{N}_{2}$ fixation of three shrub legumes periodically pruned for forage. Plant Soil 182:125-137

Peoples MB, Bowman AM, Gault RR, Herridge DF, McCallum MH, McCormick KM, Norton RM, Rochester IJ, Scammell GJ, Schwenke GD (2001) Factors regulating the contributions of fixed nitrogen by pasture and crop legumes to different farming systems of eastern Australia. Plant Soil 228:29-41

Peoples MB, Angus JF, Swan AD, Dear BS, Hauggaard-Nielsen H, Jensen ES, Ryan MH, Virgona JM (2004a) Nitrogen dynamics in legume-based pasture systems. In: Mosier AR, Syers KJ, Freney JR (eds) Agriculture and the nitrogen cycle, the Scientific Committee on Problems of the Environment (SCOPE). Island, Covelo, pp 103-114

Peoples MB, Boyer EW, Goulding KWT, Heffer P, Ochwoh VA, Vanlauwe B, Wood S, Yagi K, Van Cleemput O (2004b) Pathways of nitrogen loss and their impacts on human health and the environment. In: Mosier AR, Syers KJ, Freney JR (eds) Agriculture and the nitrogen cycle, the Scientific Committee on Problems of the Environment (SCOPE). Island, Covelo, pp 53-69

Peoples MB, Brockwell J, Herridge DF, Rochester IJ, Alves BJR, Urquiaga S, Boddey RM, Dakora FD, Bhattarai S, Maskey SL, Sampet C, Rerkasem B, Khan DF, Hauggaard-Nielsen H, Jensen ES (2009a) Review article. The contributions of nitrogen-fixing crop legumes to the productivity of agricultural systems. Symbiosis 48:1-17

Peoples MB, Hauggaard-Nielsen H, Jensen ES (2009b) The potential environmental benefits and risks derived from legumes in rotations. In: Emerich DW, Krishnan HB (eds) Agronomy Monograph 52. Nitrogen Fixation in Crop Production, Am. Soc. Agron., Crop Sci. Soc. Am., and Soil Sci. Soc Am. Madison, Wisconsin, USA, pp 349-385

Persson T, Bergkvist G, Katterer T (2008) Long-term effects of crop rotations with and without perennial leys on soil carbon stocks and grain yields of winter wheat. Nutr Cycl Agroecosyst 81:193202

Pimentel D (2003) Ethanol fuels: energy balance, economics, and environmental impacts are negative. Nat Resour Res 12:127134

Pimentel D, Patzek TW (2005) Ethanol production using corn, switchgrass, and wood; biodiesel production using soybean and sunflower. Nat Resour Res 14:65-76

Pinkerton A, Randall PJ (1994) Internal phosphorus requirements of six legumes and two grasses. Aust J Exp Agric 34:373-379

Pregelj L, McLanders JR, Gresshoff PM, Schenk PM (2011) Transcription profiling of the isoflavone phenylpropanoid pathway in soybean in response to Bradyrhizobium japonicum inoculation. Funct Plant Biol 38:13-24

Pryor SW, Lenling M, Wiesenborn DP (2008) Integrated use of field pea starch and corn for ethanol production. ASABE Paper No. 083999. ASABE, St. Joseph, MI

Radrizzani A, Shelton HM, Dalzell SA, Kirchhof G (2011) Soil organic carbon and total nitrogen under Leucaena leucocephala pastures in Queensland. Crop Pasture Sci 62:337-345

Randall GW, Huggins DR, Russelle MP, Fuchs DJ, Nelson WW, Anderson JL (1997) Nitrate losses through subsurface tile drainage in conservation reserve program alfalfa, and row crop systems. J Environ Qual 26:1240-1247 
Rathke G-W, Wienhold BJ, Wilhelm WW, Diepenbrock W (2007) Tillage and rotation effect on corn-soybean energy balances in eastern Nebraska. Soil Tillage Res 97:60-70

Reddy N, Yang Y (2009) Natural cellulose fibers from soybean straw. Biores Technol 100:3593-3598

Reid DE, Ferguson BJ, Gresshoff PM (2011) Inoculation- and nitrateinduced CLE peptides of soybean control NARK-dependent nodule formation. Mol Plant Microbe Interact 24:606-618

Rochester IJ (2003) Estimating nitrous oxide emissions from floodirrigated alkaline grey clays. Aust J Soil Res 41:197-206

Rochester IJ (2011) Sequestering carbon in minimum-tilled clay soils used for irrigated cotton and grain production. Soil Tillage Res 112:1-7

Rochester IJ, Peoples MB, Hulugalle NR, Gault RR, Constable GA (2001) Using legumes to enhance nitrogen fertility and improve soil condition in cotton cropping systems. Field Crops Res 70:27-41

Rochette P, Janzen HH (2005) Towards a revised coefficient for estimating $\mathrm{N}_{2} \mathrm{O}$ emissions from legumes. Nutr Cycl Agroecosyst 73:171-179

Rochette P, Angers DA, Bélanger G, Chantigny MH, Prévost D, Lévesque $\mathrm{G}$ (2004) Emissions of $\mathrm{N}_{2} \mathrm{O}$ from alfalfa and soybean crops in eastern Canada. Soil Sci Soc Am J 68:493-506

Rosen A, Lindgren P-E, Ljunggren H (1996) Denitrification by Rhizobium meliloti. 1. Studies of free-living cells and nodulated plants. Swed J Agric Res 26:105-113

Ruz-Jerez BE, White RE, Ball PR (1994) Long-term measurement of denitrification in three contrasting pastures grazed by sheep. Soil Biol Biochem 26:29-39

Ryan PA (1994) The use of tree legumes for fuelwood production. In: Gutteridge RC, Shelton HM (eds) Forage tree legumes in tropical agriculture. Chapter 5.1. CABI, Wallingford

Samac DA, Jung H-J, Lamb JFS (2006) Development of alfalfa ( $M$. sativa L.) as a feedstock for ethanol and other bioproducts. In: Minteer S (ed) Alcoholic fuels. CRC, Boca Raton, pp 79-98

Schwenke G, Haigh B, McMullen G, Herridge D (2010) Soil nitrous oxide emissions under dryland $\mathrm{N}$-fertilised canola and $\mathrm{N}_{2}$-fixing chickpea in the northern grains region, Australia. Proc. 19th World Congress of Soil Science, Soil Solutions for a Changing World, Brisbane, Australia, pp 228-231

Scott PT, Pregelj L, Chen N, Hadler JS, Djordjevic MA, Gresshoff PM (2008) Pongamia pinnata: an untapped resource for the biofuels industry of the future. BioEnergy Res 1:2-11

Sheehan J, Camobreco V, Duffield D, Graboski M, Shapouri H (1998) Life Cycle Inventory of Biodiesel and Petroleum Diesel for Use in an Urban Bus. 1-285. U.S. Department of Energy's Office of Fuels Development and U.S. Department of Agriculture's Office of Energy

Siah S, Konczak I, Agboola S, Wood J, Blanchard C (2011) Phenolic content and potential health benefits of Australian grown faba beans. British J Nutr (in press)

Sisti CPJ, dos Santos HP, Kochhann RA, Alves BJR, Urquiaga S, Boddey RM (2004) Change in carbon and nitrogen stocks in soil under 13 years of conventional or zero tillage in southern Brazil. Soil Tillage Res 76:39-58

Smil V (2001) Enriching the earth. MIT Press, Cambridge

Smith GB, Smith MS (1986) Symbiotic and free-living denitrification by Bradyrhizobium japonicum. Soil Sci Soc Am J 50:349-354

Smith P, Martino D, Cai C, Gwary D, Janzen H, Kumar P, McCarl B, Ogle S, O'Mara F, Rice C, Scholes B, Sirotenko O (2007) Agriculture. In: Metz B, Davidson OR, Bosch PR, Dave R, Meyer LA (eds) Climate Change 2007, Mitigation. Contribution of Working Group III to the Fourth Assessment Report of the Intergovernmental Panel on Climate Change. Cambridge University Press, Cambridge

Soares LH de B, Muniz LC, Figueiredo RS, Alves BJR, Boddey RM, Urquiaga S, Madari BE, Machado PLO de A (2007) Balanço energético de um sistema integrado lavoura-pecuária no Cerrado. Bol. Pesq.Desenvolv. No. 26, Embrapa Agrobiologia, Seropédica (available online at: www.cnpab.embrapa.br/publicacoes/download/ bot026.pdf)

Soussana JF, Loiseau P, Vuichard N, Ceschia E, Balesdent J, Chevallier T, Arrouays D (2004) Carbon cycling and sequestration opportunities in temperate grasslands. Soil Use Manag 20:219-230

Soussana JF, Tallec T, Blanfort V (2010) Mitigating the greenhouse gas balance of ruminant production systems through carbon sequestration in grasslands. Animal 4:334-350

Stehfest E, Bouwman L (2006) $\mathrm{N}_{2} \mathrm{O}$ and $\mathrm{NO}$ emissions from agricultural fields and soils under natural vegetation: summarizing available measurement data and modeling of global annual emissions. Nutr Cycl Agroecosyst 74:207-228

Stewart CE, Plante AF, Paustian K, Conant RT (2008) Soil carbon saturation: linking concept and measurable carbon pools. Soil Sci Soc Am J 72:379-813

Szott LT, Palm CA, Buresh RJ (1999) Ecosystem fertility and fallow function in the humid and subhumid tropics. Agrofor Syst 47:163-196

Tarré R, Macedo R, Cantarutti RB, de Rezende PC, Pereira JM, Ferreira E, Alves BJR, Urquiaga S, Boddey RM (2001) The effect of the presence of a forage legume on nitrogen and carbon levels in soils under Brachiaria pastures in the Atlantic forest region of the South of Bahia, Brazil. Plant Soil 234:15-26

Teira-Esmatges MR, Van Cleemput O, Porta-Casnellas J (1998) Fluxes of nitrous oxide and molecular nitrogen from irrigated soils of Catalonia (Spain). J Environ Qual 27:687-697

Thomsen MH, Hauggaard-Nielsen H (2008) Sustainable bioethanol production combining biorefinery principles using combined raw materials from straw and clover-grass. J Ind Microbiol Biotech 35:303-311

Thrall PH, Millsom DA, Jeavons AC, Waayers M, Harvey GR, Bagnall DJ, Brockwell J (2005) Seed inoculation with effective root-nodule bacteria enhances revegetation success. J Appl Ecol 42:740-751

Torres AQA, Jantalia CP, Franco AA, Campello EFC, Resende AS, Urquiaga S, Macedo MO, Moreira JF, Alves TG (2007) Influência de espécies de leguminosas fixadoras de nitrogênio no estoque de $\mathrm{C}$ no solo em plantio consorciado no bioma Mata Atlântica (in Portuguese, with English abstract). Congresso Brasileiro de Ciência do Solo 5 to 10 August, Gramada, RS. 3 p. CD-ROM

Udvardi MK, Price GD, Gresshoff PM, Day DA (1988) A dicarboxylate transporter on the peribacteroid membrane of soybean nodules. FEBS Lett 231:36-40

van Berkum P, Keyser HH (1985) Anaerobic growth and denitrification among different serogroups of soybean rhizobia. Appl Environ Microbiol 49:772-777

VandenBygaart AJ, Gregorich EG, Angers DA (2003) Influence of agricultural management on soil organic carbon: a compendium and assessment of Canadian studies. Can J Soil Sci 83:363-380

Venendaal R, Jørgensen U, Foster CA (1997) European energy crops. Biomass Bioenerg 13:147-185

Wagner-Riddle C, Thurtell GW (1998) Nitrous oxide emissions from agricultural fields during winter and spring thaw as affected by management practices. Nutr Cycl Agroecosyst 52:151-163

Wagner-Riddle C, Thurtell GW, Kidd GK, Beauchamp EG, Sweetman R (1997) Estimates of nitrous oxide emissions from agricultural fields over 28 months. Can J Soil Sci 77:135-144

Wichern F, Eberhardt E, Mayer J, Joergensen RG, Müller T (2008) Nitrogen rhizodeposition in agricultural crops: methods, estimates and future prospects. Soil Biol Biochem 40:30-48

Whitbread AM, Blair GJ, Lefroy RDB (2000) Managing legume leys, residues and fertilisers to enhance the sustainability of wheat cropping systems in Australia. 2. Soil physical fertility and carbon. Soil Tillage Res 54:77-89 
Wilkinson CS, Fuskhah E, Indrasumunar A, Gresshoff PM, Scott PT (2012) Growth, nodulation and nitrogen gain of Pongamia pinnata and Glycine max in response to salinity. BioEnergy Res (in review)

Williams CH, Donald CM (1957) Changes in organic matter and $\mathrm{pH}$ in a podzolic soil as influenced by subterranean clover and superphosphate. Aust J Agric Res 8:179-189

Wright AL, Hons FM, Rouquette FM Jr (2004) Long-term management impacts on soil carbon and nitrogen dynamics of grazed bermudagrass pastures. Soil Biol Biochem $36: 1806-1816$

Yang L, Cai Z (2005) The effect of growing soybean (Glycine max. L.) on $\mathrm{N}_{2} \mathrm{O}$ emission from soil. Soil Biol Biochem 37:1205-1209

Young RR, Wilson B, Harden S, Bernardi A (2009) Accumulation of soil carbon under zero tillage cropping and perennial vegetation on the Liverpool Plains, eastern Australia. Aust J Soil Res 47:273-285

Zapata F, Danso SKA, Hardarson G, Fried M (1987) Time course of nitrogen fixation in field-grown soybean using Nitrogen-15 methodology. Agron J 79:172-176

Zentner RP, Campbell CA, Biederbeck VO, Miller PR, Selles F, Fernandez MR (2001) In search of a sustainable cropping system for the semiarid Canadian prairies. J Sustain Agric 18:117-136

Zentner RP, Lafond GP, Derksen DA, Nagy CN, Wall DD, May WE (2004) Effects of tillage method and crop rotation on nonrenewable energy use efficiency for a thin Black Cherozem in the Canadian prairies. Soil Tillage Res 77:125-136

Zhong Z, Lemke RL, Nelson LM (2009) Nitrous oxide emissions associated with nitrogen fixation by grain legumes. Soil Biol Biochem 41:2283-2291 